US Army Corps

of Engineers

Waterways Experiment

Station

\title{
Low-Head Navigation Dam Stilling Basin Design
}

by John E. Hite, Jr. 
The contents of this report are not to be used for advertising, publication, or promotional purposes. Citation of trade names does not constitute an official endorsement or approval of the use of such commercial products.

The findings of this report are not to be construed as an official Department of the Army position, unless so designated by other authorized documents. 


\section{Low-Head Navigation Dam Stilling Basin Design}

by John E. Hite, Jr.

U.S. Army Corps of Engineers

Waterways Experiment Station

3909 Halls Ferry Road

Vicksburg, MS 39180-6199

Final report

Approved for public release; distribution is unlimited 


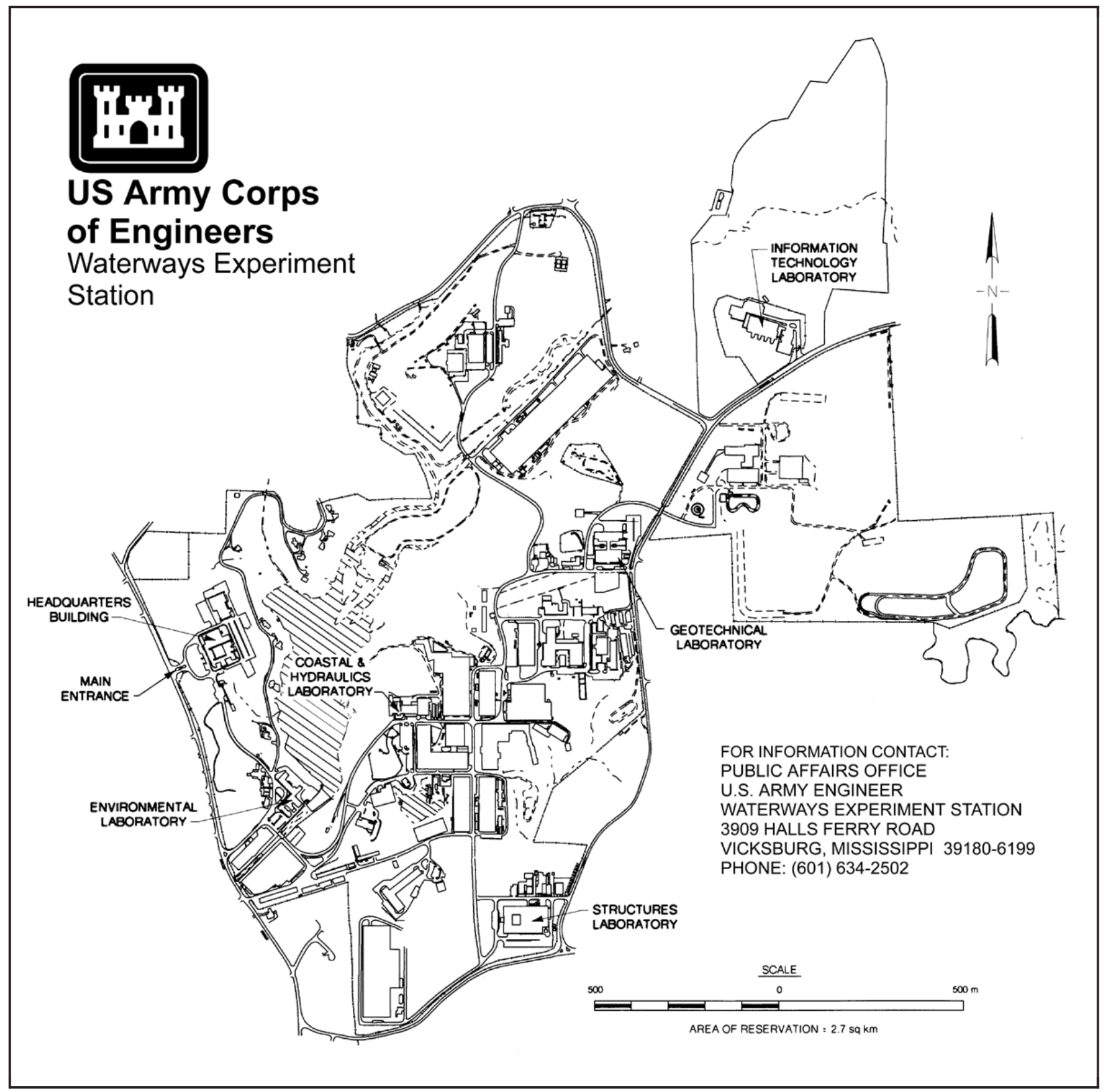

Waterways Experiment Station Cataloging-in-Publication Data

Hite, John E.

Low-head navigation dam stilling basin design / by John E. Hite ; prepared for U.S. Army Corps of Engineers.

76 p. : ill. ; $28 \mathrm{~cm}$. - (Technical report ; CHL-99-4)

Includes bibliographic references.

1. Stilling basins - Design and construction. 2. Dams. 3. Spillways. 4. Navigation. I. United States. Army. Corps of Engineers. II. U.S. Army Engineer Waterways Experiment Station. III. Coastal and Hydraulics Laboratory (U.S. Army Engineer Waterways Experiment Station) IV. Title. V. Series: Technical report (U.S. Army Engineer Waterways Experiment Station) ; CHL-99-4.

TA7 W34 no.CHL-99-4 


\section{Contents}

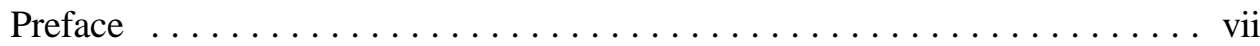

Conversion Factors, Non-SI to SI Units of Measurement $\ldots \ldots \ldots \ldots \ldots$ viii

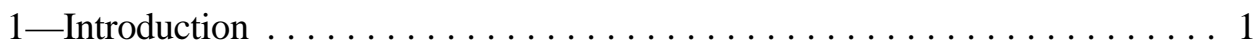

2-Literature Review ...................... 5

3-Hydraulics of Low-Head Navigation Dam Stilling Basins . . . . . . . . . 48

4-Available Design Procedures $\ldots \ldots \ldots \ldots \ldots \ldots \ldots \ldots \ldots \ldots \ldots$

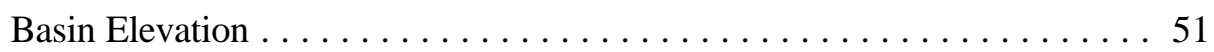

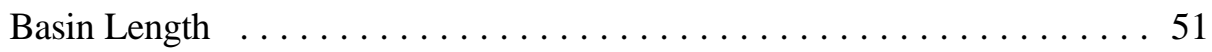

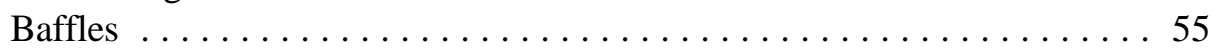

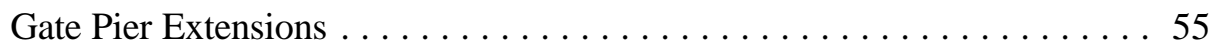

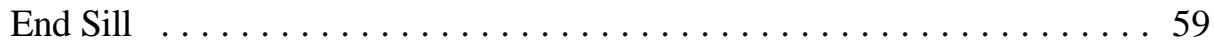

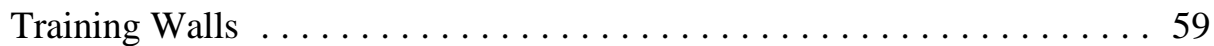

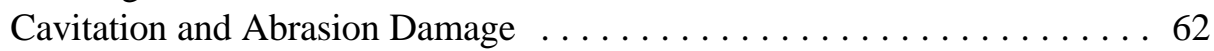

5-Summary and Conclusions .................. 63

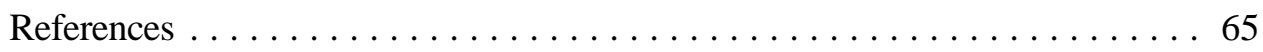

SF 298

\section{List of Figures}

Figure 1. Definition of stilling basin elements $\ldots \ldots \ldots \ldots \ldots \ldots \ldots$

Figure 2. Section view of Emsworth Dam stilling basin $\ldots \ldots \ldots \ldots \ldots$

Figure 3. Details of stilling basin model tested for Warrior Dam,

Warrior River ................... 8 
Figure 4. Comparison of flow characteristics with Types 1 and 22

stilling basins model tested for Warrior Dam . . . . . . . . 9

Figure 5. Submergible tainter-gate stilling basin designs tested in Markland model study $\ldots \ldots \ldots \ldots \ldots \ldots \ldots$

Figure 6. Gate sills for nonsubmergible gates tested in Markland

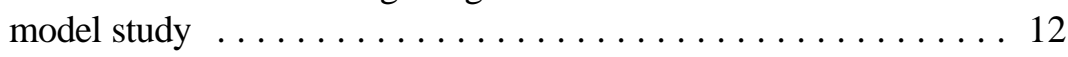

Figure 7. Stilling basin recommended from model study of

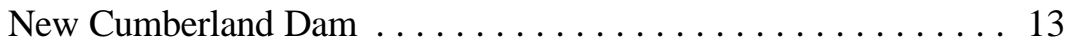

Figure 8. Stilling basin recommended from model studies of typical low-head navigation dams on Arkansas River . . . . . . . . 14

Figure 9. Comparison of scour patterns for Arkansas River stilling

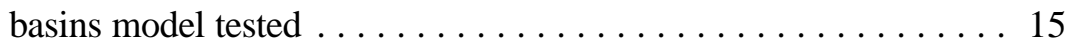

Figure 10. Undulating jet in stilling basin $\ldots \ldots \ldots \ldots \ldots \ldots \ldots \ldots$

Figure 11. Stilling basin designs tested in model study of Pike Island

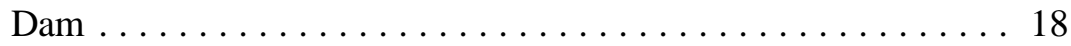

Figure 12. Stilling basin designs tested during model study of Belleville Dam ....................... 19

Figure 13. Stilling basin designs tested during model study of

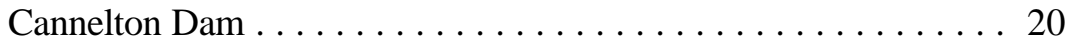

Figure 14. Stilling basin designs tested during model study of

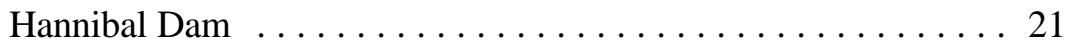

Figure 15. Stilling basins model tested during study of Aliceville Dam . . . 23

Figure 16. Stilling basins model tested during study of Columbus Dam . . . 24

Figure 17. Stilling basins tested during model study of Lock and Dam No. $26 \ldots \ldots \ldots \ldots \ldots \ldots \ldots$

Figure 18. Stilling basins model tested during study of Red River Lock and Dam No. 1 . . . . . . . . . . . . . 27

Figure 19. Stilling basins model tested during study of John H.

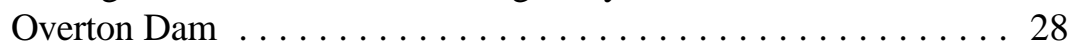

Figure 20. Stilling basin for Montgomery Dam $\ldots \ldots \ldots 30$

Figure 21. Pike Island Dam stilling basin under construction $\ldots \ldots \ldots 31$ 
Figure 22. Secondary stilling basin tested during model study of

Morgantown Dam .................... 32

Figure 23. Secondary stilling basin model tested for Dam No. 2

Arkansas River . . . . . . . . . . . . . . . . . . . 33

Figure 24. Secondary stilling basin constructed of concrete and riprap-model tested for Dam No. 2 Arkansas River . . . . . . . 34

Figure 25. Artist's conception of navigation accident at Dam No. 2

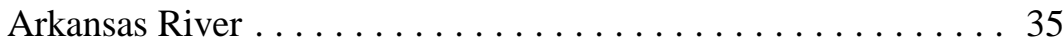

Figure 26. Details of stilling basin model tested for REMR research . . . . . 36

Figure 27. Model of low-head navigation dam stilling basin used

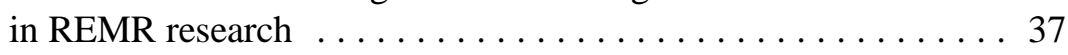

Figure 28. Flow conditions with normal upper pool, minimum tailwater, and center gate fully open $\ldots \ldots \ldots \ldots \ldots \ldots$

Figure 29. Velocities over end sill of REMR research model . . . . . . . . 40

Figure 30. Velocities measured along center line of scour hole

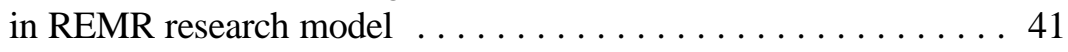

Figure 31. Plan view of velocities measured in REMR research model, $1 \mathrm{ft}$ above bottom $\ldots \ldots \ldots \ldots \ldots \ldots \ldots \ldots \ldots \ldots \ldots \ldots \ldots \ldots \ldots$

Figure 32. Plan view of velocities measure in REMR research model $1 \mathrm{ft}$ below surface $\ldots \ldots \ldots \ldots \ldots \ldots \ldots \ldots \ldots$

Figure 33. Velocities over end sill of REMR research model—no baffles . . . 44

Figure 34. Flow conditions in stilling basin with gate pier extensions . . . . 46

Figure 35. Flow conditions in stilling basin without gate pier extensions . . . 47

Figure 36. Plot of $T W / d_{2}$ versus $F_{1}$ for model stilling basins shown in

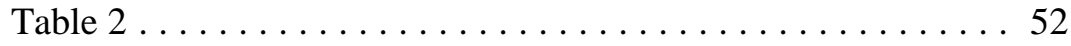

Figure 37. Plot of $L_{2} / d_{2}$ and $L_{3} / d_{2}$ versus $F_{1}$ for model stilling basins shown in Table $2 \ldots \ldots \ldots \ldots \ldots \ldots \ldots \ldots \ldots \ldots \ldots \ldots \ldots \ldots \ldots \ldots$

Figure 38. Plot of $h / d_{2}$ versus $F_{1}$ for model stilling basins shown

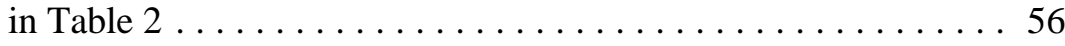

Figure 39. Plot of $h / d_{1}$ versus $F_{l}$ for model stilling basins shown

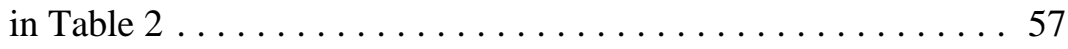


Figure 40. Plot of $L_{l} / d_{2}$ versus $F_{1}$ for model stilling basins shown

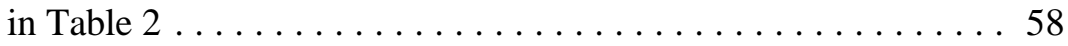

Figure 41. Plot of $h^{\prime} / d_{2}$ versus $F_{e s}$, for model stilling basins shown

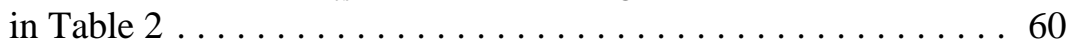

Figure 41. Plot of $h^{\prime} / d_{2}$ versus $F_{1}$ for model stilling basins shown in Table $2 \ldots \ldots \ldots \ldots \ldots \ldots \ldots \ldots \ldots \ldots \ldots \ldots \ldots \ldots \ldots$ 


\section{Preface}

The investigation reported herein was authorized by Headquarters, U.S. Army Corps of Engineers.

The studies were conducted by personnel of the Coastal and Hydraulics Laboratory (CHL), U.S. Army Engineer Waterways Experiment Station (WES) under the direction of Messrs. Frank A. Herrmann, Jr. (retired), former Director, Hydraulics Laboratory (HL), Glenn A. Pickering (retired), former Chief, Hydraulic Structures Division, HL, and Thomas J. Pokrefke, Estuaries and Hydroscience Division, CHL. This report was prepared by Dr. John E. Hite, Jr., under the supervision of Mr. John F. George, Chief, Fisheries Hydrodynamics Branch, CHL.

At the time of publication of this report, COL Robin R. Cababa, EN, was Commander of WES.

The contents of this report are not to be used for advertising, publication, or promotional purposes. Citation of trade names does not constitute an official endorsement or approval of the use of such commercial products. 


\section{Conversion Factors, Non-SI to SI Units of Measurement}

Non-SI units of measurement used in this report can be converted to SI units as follows:

\begin{tabular}{|l|l|l|}
\hline \hline Multiply & By & To Obtain \\
\hline \hline cubic feet & 0.02831685 & cubic meters \\
\hline feet & 0.3048 & meters \\
\hline
\end{tabular}




\section{Introduction}

The function of a navigation dam is to provide a navigation pool that allows tows to travel the river. The navigation project usually consists of the dam, a spillway (gated and/or ungated), a stilling basin downstream from the spillway, a navigation lock, and sometimes hydropower capability. The purpose of the stilling basin is to dissipate the energy of the spillway flow to minimize the chances of extensive scour downstream from the structure that could undermine or otherwise threaten the integrity of the project. Low-head in this report refers to $40 \mathrm{ft}^{1}$ or less. The components of the navigation dam stilling basin that will be discussed in this report are shown in Figure 1.

Project operation schedules are an essential consideration in stilling basin design. The stilling basins for projects constructed 40 years ago or more were designed based on an equal distribution of flow through the spillway gates. Experience has shown that this type of operation is not always possible. Often times, the gated spillway is used to pass ice or debris required to keep the navigation channel open. Navigation accidents have also caused situations where equal gate operations were not possible. Other circumstances that can cause unusual operating conditions are malfunction of the gate hoisting mechanism and even vandalism. Many projects have been severely damaged as a result of these types of operating conditions.

New guidance for the design of navigation dam stilling basins found in EM 1110-2-1605 (U.S. Army Corps of Engineers (USACE) 1987) states that unusual or emergency operation must be considered. New project stilling basin design must consider the following conditions:

a. Uniform discharge through all the spillway gates for a range of headwaters and tailwaters expected during project life.

$b$. Single gate fully opened with normal headwater and minimum tailwater. This is considered gate misoperation and would only occur for an emergency condition. Minor damage to the downstream scour protection is acceptable as long as the integrity of the structure is not jeopardized.

1 A table of factors for converting non-SI units of measurement to SI units is presented on page viii. 


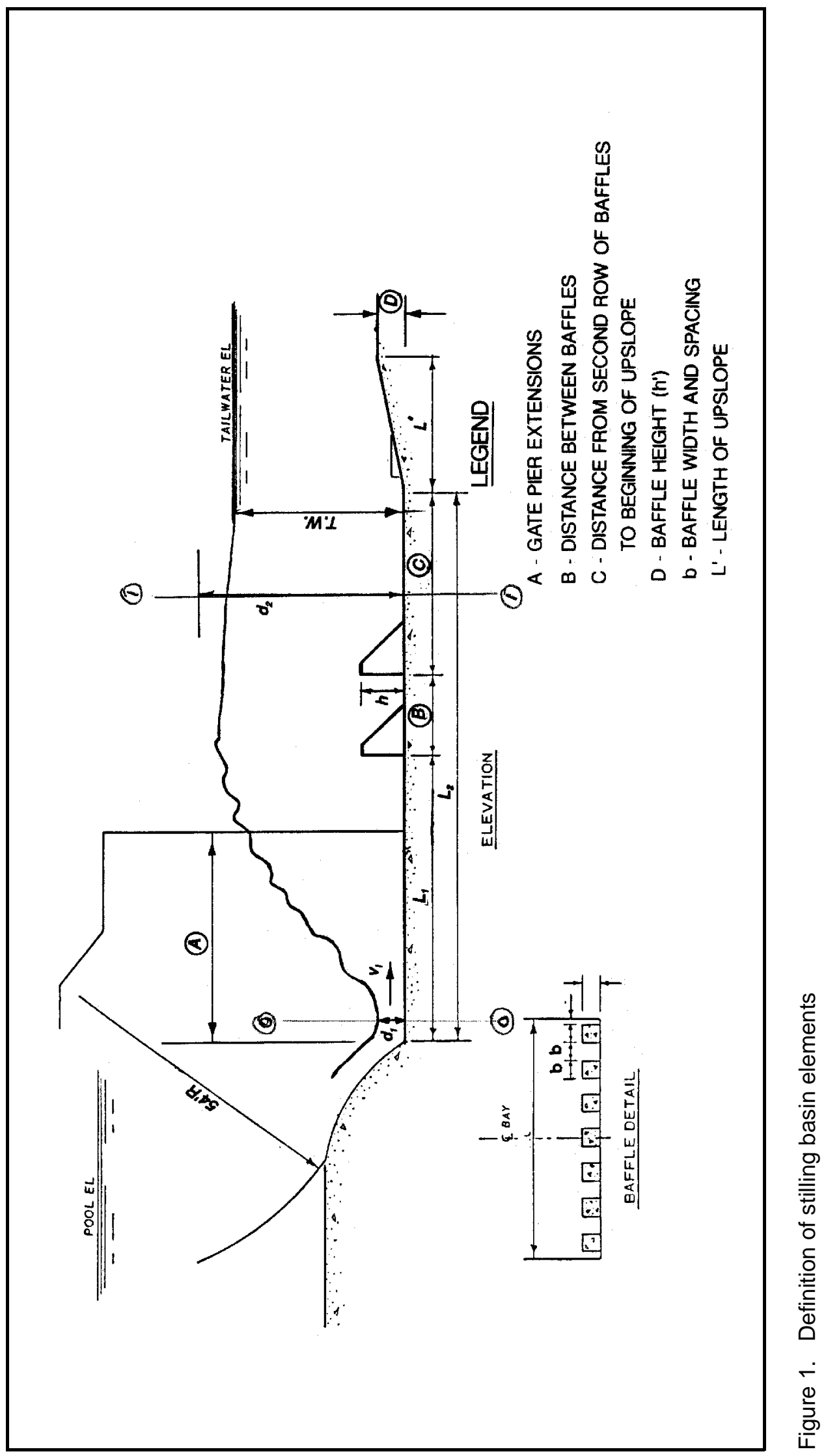


Single gate fully opened with above normal pool (perhaps the 50- to 100 -year pool) should be considered. This condition could occur as a result of a navigation accident.

c. Single gate open sufficiently wide to pass floating ice or drift at normal headwater and minimum tailwater. During preliminary design, a gate half opened can be used to approximate this ice- or drift-passing condition. No damage is acceptable for this condition. Final design usually requires model studies to determine the proper gate opening.

The three conditions above are used to optimize stilling basin length and downstream scour-protection thickness, size, and length. Structure foundation will affect the design condition. Those structures founded on nonerodible rock could have lesser requirements for stilling basin and downstream protection.

A majority of the existing low-head navigation dams are located on and east of the Mississippi River in erodible material. Significant efforts should be made to design the stilling basin and downstream channel for optimum energy dissipation and protection for these projects. History has shown that nearly everyone of the existing low-head navigation dams have significant scour downstream from them. The scour has resulted from operating conditions and/or flow conditions changing from what the project was designed for and often from inadequate energy dissipation in the stilling basin.

An example of conditions changing was observed at Emsworth Locks and Dams on the Ohio River. This project was originally constructed in 1919-1922 as a fixed-crest spillway and later modified in 1935-1938 to provide gated crests that would raise the Emsworth pool $7 \mathrm{ft}$. Portions of the old dam were used in constructing the new spillway section as shown in Figure 2. This resulted in a stilling basin that was not a very good energy dissipater. Also, the streambed downstream from the dam has eroded, which has resulted in a lower tailwater elevation. Presently, the minimum tailwater elevation is below the stilling basin apron elevation. These changing conditions illustrate why significant scour occurred at this project. Much information has been gained from observing the performance of these older structures, and this information should not be overlooked in the design of a new project. 


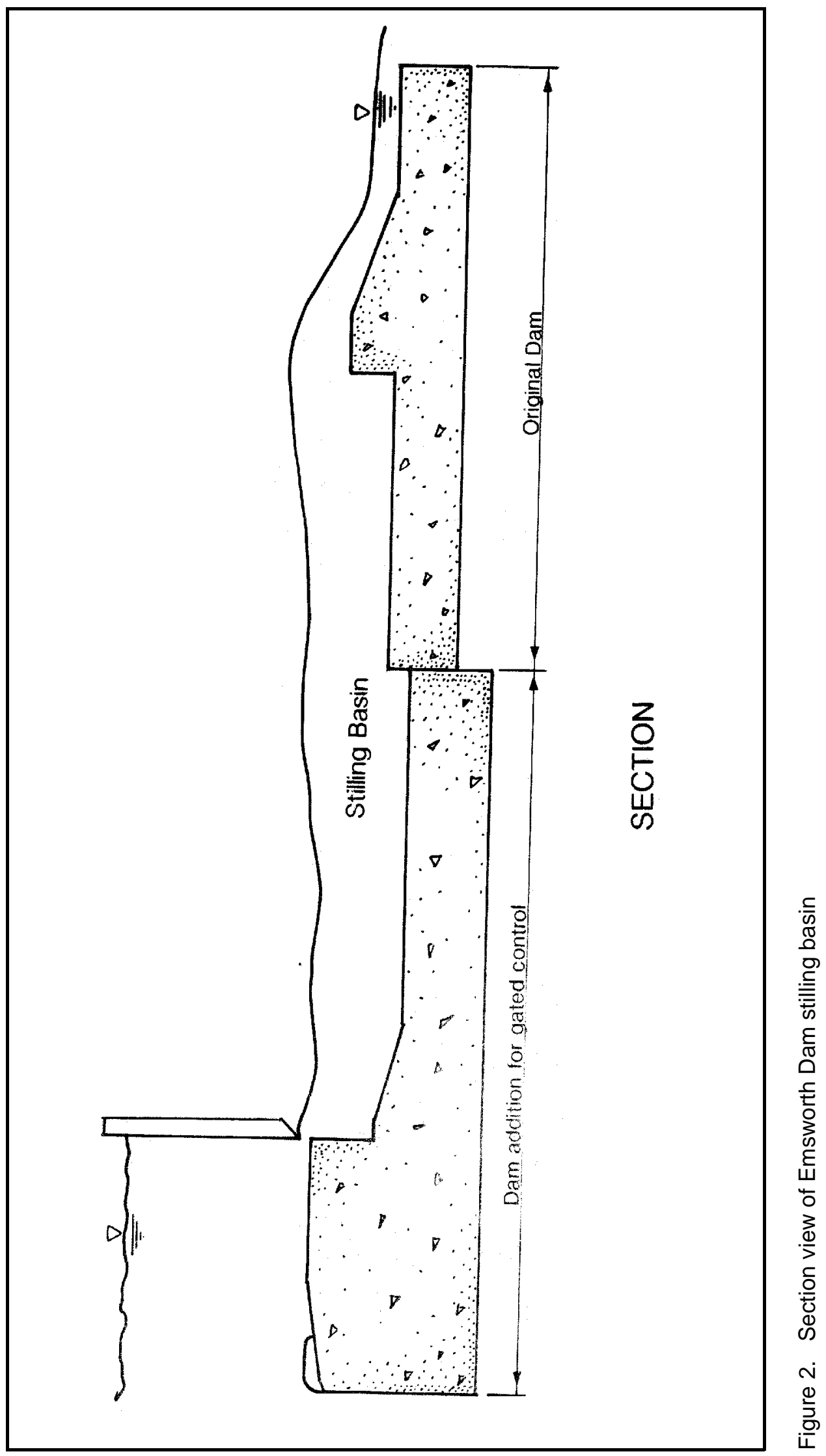




\section{Literature Review}

This section presents a review of the pertinent literature concerning the design of low-head navigation dam stilling basins. Many model studies performed at the U.S. Army Engineer Waterways Experiment Station (WES) were reviewed to determine how the stilling basin designs were developed.

WES (1958) conducted a model study to address stilling basin performance at Warrior Dam, Warrior River, Alabama. The model tests indicated that the most severe hydraulic conditions in the stilling basin occurred during rising stages with a discharge of 37,900 cfs (Step 37 in gate-operating schedule for rising stage shown in Table 1, one interior gate open $8 \mathrm{ft}$, other gates open $5 \mathrm{ft}$ ). The gate-operating schedule in Table 1 illustrates equal gate operations. Uniform flow distributions are achieved by manipulating the gates in this manner. One should notice that as the discharge increases, the middle gates are raised first to pass the increasing flow. Adjacent gates with openings more than $2 \mathrm{ft}$ apart are not desired as evidenced by the flow conditions observed in this model study. The various stilling basin designs were evaluated for a discharge of 37,900 cfs (unit $\mathrm{q}=95 \mathrm{cfs} / \mathrm{ft}$ ) since this was considered the most severe hydraulic condition. The original and recommended stilling basins are shown in Figure 3. Watersurface profiles and flow characteristics observed with the two basins are shown in Figure 4. The differences between the recommended and the original design are the location of the first row of baffle piers (blocks) $4 \mathrm{ft}$ farther downstream, the increase in the spacing between the baffles of $0.33 \mathrm{ft}$, and the shape of the crest. A reduction in the velocities over the end sill was the basis for choosing the recommended design. Two items should be noted here. First, the model reproduced one full gate bay and only portions of the adjacent gate bays; and second, emergency operating conditions were not investigated. Scour downstream from this project to date does not appear to be a problem.

In the 1950s, model studies were conducted for low-head navigation dams to be located on the Ohio River. The studies were conducted for various reasons, and often the stilling basin design was investigated during the course of many of the studies. WES (1961a) conducted a model study on Markland Dam, Ohio River, to evaluate the stilling basin performance. The conditions the stilling basin was required to operate were as follows: the gates would be operated in increments no more than $2 \mathrm{ft}$, and the maximum difference in opening of any two gates would not be allowed to exceed $2 \mathrm{ft}$. Further, it was desired that the stilling basin perform adequately with all 12 gates operating and with 11 gates 


\begin{tabular}{|c|c|c|c|c|c|c|c|c|}
\hline \multicolumn{9}{|c|}{$\begin{array}{l}\text { Table } 1 \\
\text { Gate-Operation Schedule for Warrior Dam Spillway }\end{array}$} \\
\hline \multirow{2}{*}{$\begin{array}{l}\text { Step } \\
\text { No. }\end{array}$} & \multirow{2}{*}{$\begin{array}{l}\text { Discharge } \\
\text { cfs }\end{array}$} & \multirow{2}{*}{$\begin{array}{l}\text { Tailwater } \\
\text { el }\end{array}$} & \multicolumn{6}{|c|}{$\begin{array}{l}\text { Vertical Distance in Feet from } \\
\text { Spillway Crest to Bottom of Gate }\end{array}$} \\
\hline & & & Gate 1 & Gate 2 & Gate 3 & Gate 4 & Gate 5 & Gate 6 \\
\hline 1 & 900 & 73.25 & Closed & Closed & 0.5 & Closed & Closed & Closed \\
\hline 2 & 1,800 & 73.55 & Closed & Closed & 0.5 & Closed & 0.5 & Closed \\
\hline 3 & 2,700 & 73.90 & 0.5 & Closed & 0.5 & Closed & 0.5 & Closed \\
\hline 4 & 3,600 & 74.20 & 0.5 & Closed & 0.5 & Closed & 0.5 & 0.5 \\
\hline 5 & 4,500 & 74.50 & 0.5 & 0.5 & 0.5 & Closed & 0.5 & 0.5 \\
\hline 6 & 5,400 & 74.90 & 0.5 & 0.5 & 0.5 & 0.5 & 0.5 & 0.5 \\
\hline 7 & 6,285 & 75.20 & 0.5 & 0.5 & 1.0 & 0.5 & 0.5 & 0.5 \\
\hline 8 & 7,170 & 75.50 & 0.5 & 0.5 & 1.0 & 0.5 & 1.0 & 0.5 \\
\hline 9 & 8,055 & 75.85 & 1.0 & 0.5 & 1.0 & 0.5 & 1.0 & 0.5 \\
\hline 10 & 8,940 & 76.20 & 1.0 & 0.5 & 1.0 & 0.5 & 1.0 & 1.0 \\
\hline 11 & 9,825 & 76.55 & 1.0 & 1.0 & 1.0 & 0.5 & 1.0 & 1.0 \\
\hline 12 & 10,710 & 76.95 & 1.0 & 1.0 & 1.0 & 1.0 & 1.0 & 1.0 \\
\hline 13 & 11,585 & 77.30 & 1.0 & 1.0 & 1.5 & 1.0 & 1.0 & 1.0 \\
\hline 14 & 12,460 & 77.65 & 1.0 & 1.0 & 1.5 & 1.0 & 1.5 & 1.0 \\
\hline 15 & 13,335 & 77.95 & 1.5 & 1.0 & 1.5 & 1.0 & 1.5 & 1.0 \\
\hline 16 & 14,210 & 78.30 & 1.5 & 1.0 & 1.5 & 1.0 & 1.5 & 1.5 \\
\hline 17 & 15,085 & 78.70 & 1.5 & 1.5 & 1.5 & 1.0 & 1.5 & 1.5 \\
\hline 18 & 15,960 & 79.05 & 1.5 & 1.5 & 1.5 & 1.5 & 1.5 & 1.5 \\
\hline 19 & 16,800 & 79.35 & 1.5 & 1.5 & 2.0 & 1.5 & 1.5 & 1.5 \\
\hline 20 & 17,650 & 79.70 & 1.5 & 1.5 & 2.0 & 1.5 & 2.0 & 1.5 \\
\hline 21 & 18,525 & 80.10 & 2.0 & 1.5 & 2.0 & 1.5 & 2.0 & 1.5 \\
\hline 22 & 19,260 & 80.45 & 2.0 & 1.5 & 2.0 & 1.5 & 2.0 & 2.0 \\
\hline 23 & 20,010 & 80.80 & 2.0 & 2.0 & 2.0 & 1.5 & 2.0 & 2.0 \\
\hline 24 & 20,700 & 81.15 & 2.0 & 2.0 & 2.0 & 2.0 & 2.0 & 2.0 \\
\hline 25 & 21,890 & 81.60 & 2.0 & 2.0 & 3.0 & 2.0 & 2.0 & 2.0 \\
\hline 26 & 23,060 & 82.10 & 2.0 & 2.0 & 3.0 & 2.0 & 3.0 & 2.0 \\
\hline 27 & 24,180 & 82.60 & 3.0 & 2.0 & 3.0 & 2.0 & 3.0 & 2.0 \\
\hline 28 & 25,300 & 83.10 & 3.0 & 2.0 & 3.0 & 2.0 & 3.0 & 3.0 \\
\hline 29 & 26,360 & 83.60 & 3.0 & 3.0 & 3.0 & 2.0 & 3.0 & 3.0 \\
\hline 30 & 27,420 & 84.05 & 3.0 & 3.0 & 3.0 & 3.0 & 3.0 & 3.0 \\
\hline 31 & 29,090 & 84.70 & 3.0 & 3.0 & 3.0 & 3.0 & 3.0 & 3.0 \\
\hline
\end{tabular}




\begin{tabular}{|c|c|c|c|c|c|c|c|c|}
\hline \multicolumn{9}{|c|}{ Table 1 (Concluded) } \\
\hline \multirow{2}{*}{$\begin{array}{l}\text { Step } \\
\text { No. }\end{array}$} & \multirow{2}{*}{$\begin{array}{l}\text { Discharge } \\
\text { cfs }\end{array}$} & \multirow{2}{*}{$\begin{array}{l}\text { Tailwater } \\
\text { el }\end{array}$} & \multicolumn{6}{|c|}{$\begin{array}{l}\text { Vertical Distance in Feet from } \\
\text { Spillway Crest to Bottom of Gate }\end{array}$} \\
\hline & & & Gate 1 & Gate 2 & Gate 3 & Gate 4 & Gate 5 & Gate 6 \\
\hline 32 & 30,640 & 85.45 & 3.0 & 3.0 & 5.0 & 3.0 & 5.0 & 3.0 \\
\hline 33 & 32,200 & 86.10 & 5.0 & 3.0 & 5.0 & 3.0 & 5.0 & 3.0 \\
\hline 34 & 33,780 & 86.70 & 5.0 & 3.0 & 5.0 & 3.0 & 5.0 & 5.0 \\
\hline 35 & 35,130 & 87.25 & 5.0 & 5.0 & 5.0 & 3.0 & 5.0 & 5.0 \\
\hline 36 & 36,300 & 87.70 & 5.0 & 5.0 & 5.0 & 5.0 & 5.0 & 5.0 \\
\hline 37 & 37,900 & 88.35 & 5.0 & 5.0 & 8.0 & 5.0 & 5.0 & 5.0 \\
\hline 38 & 39,560 & 88.90 & 5.0 & 5.0 & 8.0 & 5.0 & 8.0 & 5.0 \\
\hline 39 & 40,770 & 89.40 & 8.0 & 5.0 & 8.0 & 5.0 & 8.0 & 5.0 \\
\hline 40 & 42,040 & 89.90 & 8.0 & 5.0 & 8.0 & 5.0 & 8.0 & 5.0 \\
\hline 41 & 43,060 & 90.30 & 8.0 & 8.0 & 8.0 & 5.0 & 8.0 & 8.0 \\
\hline 42 & 44,100 & 90.65 & 8.0 & 8.0 & 8.0 & 8.0 & 8.0 & 8.0 \\
\hline 43 & 45,780 & 91.20 & 8.0 & 8.0 & 12.0 & 8.0 & 8.0 & 8.0 \\
\hline 44 & 47,000 & 91.67 & 8.0 & 8.0 & 12.0 & 8.0 & 12.0 & 8.0 \\
\hline 45 & 47,910 & 92.05 & 12.0 & 8.0 & 12.0 & 8.0 & 12.0 & 8.0 \\
\hline 46 & 48,920 & 92.33 & 12.0 & 8.0 & 12.0 & 8.0 & 12.0 & 12.0 \\
\hline 47 & 49,560 & 92.60 & 12.0 & 12.0 & 12.0 & 8.0 & 12.0 & 12.0 \\
\hline 48 & 50,280 & 92.80 & 12.0 & 12.0 & 12.0 & 12.0 & 12.0 & 12.0 \\
\hline 49 & 52,600 & 93.32 & 12.0 & 12.0 & Open & Open & 12.0 & 12.0 \\
\hline 50 & 53,340 & 93.78 & 12.0 & Open & Open & Open & Open & 12.0 \\
\hline 51 & 54,300 & 94.15 & Open & Open & Open & Open & Open & Open \\
\hline
\end{tabular}

operating and the twelfth gate assumed inoperative in a closed position. For these conditions, the model was used to establish tailwater limits for each gate position. The design of the stilling basin was complicated by the use of submergible gates that required a nondesirable gate sill shape. The Type 1 basin shown in Figure 5 produced satisfactory flow conditions, but an undesirable flow condition could be established in the model by allowing supercritical flow to enter the basin by lowering the normal tailwater. Once this occurred, and the tailwater was raised back to its previous setting, an undulating jet (submerged nappe) action resulted rather than jump-type action as desired. This undulating jet action created very high bottom velocities for certain gate openings. The Type 6 basin shown in Figure 5 was adopted because of lower bottom velocities observed with this basin. Comparative scour tests were conducted with the Type 6 basin to determine the optimum end sill configuration. Based on the 


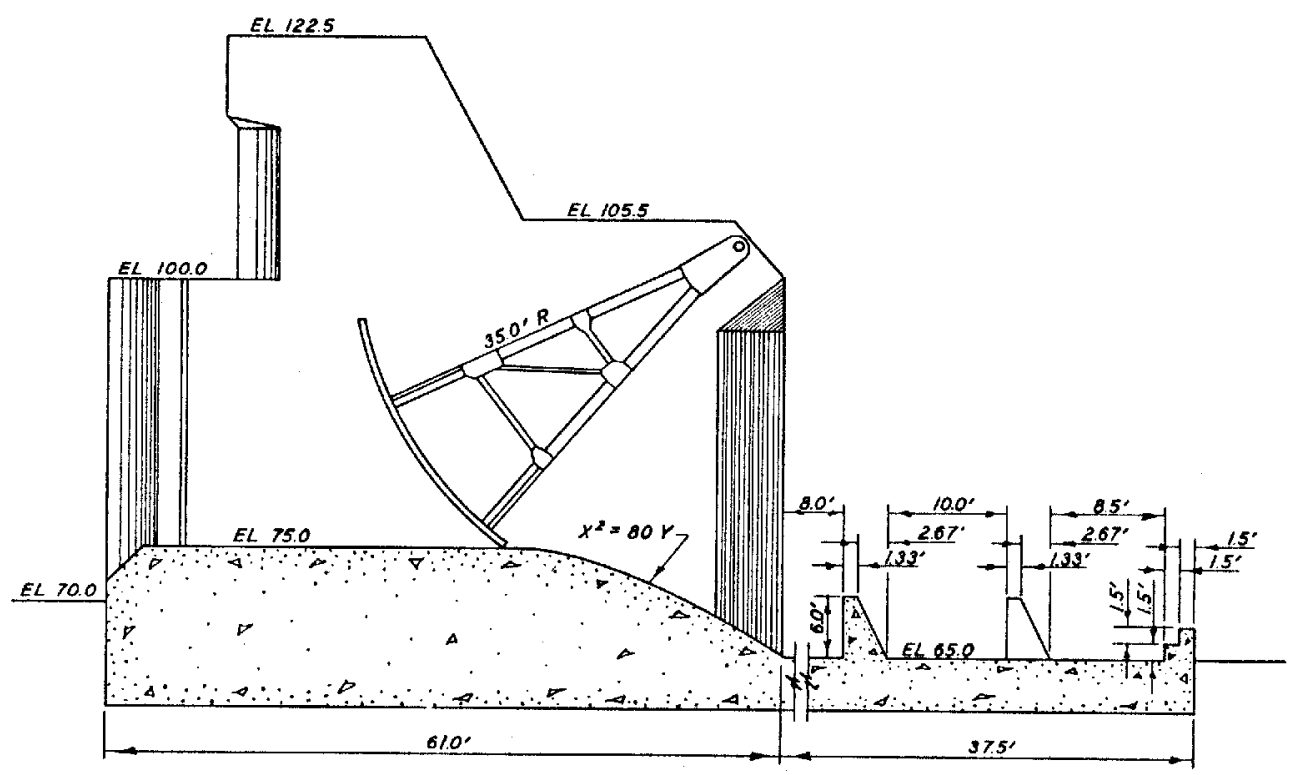

TYPE I (ORIGINAL) DESIGN

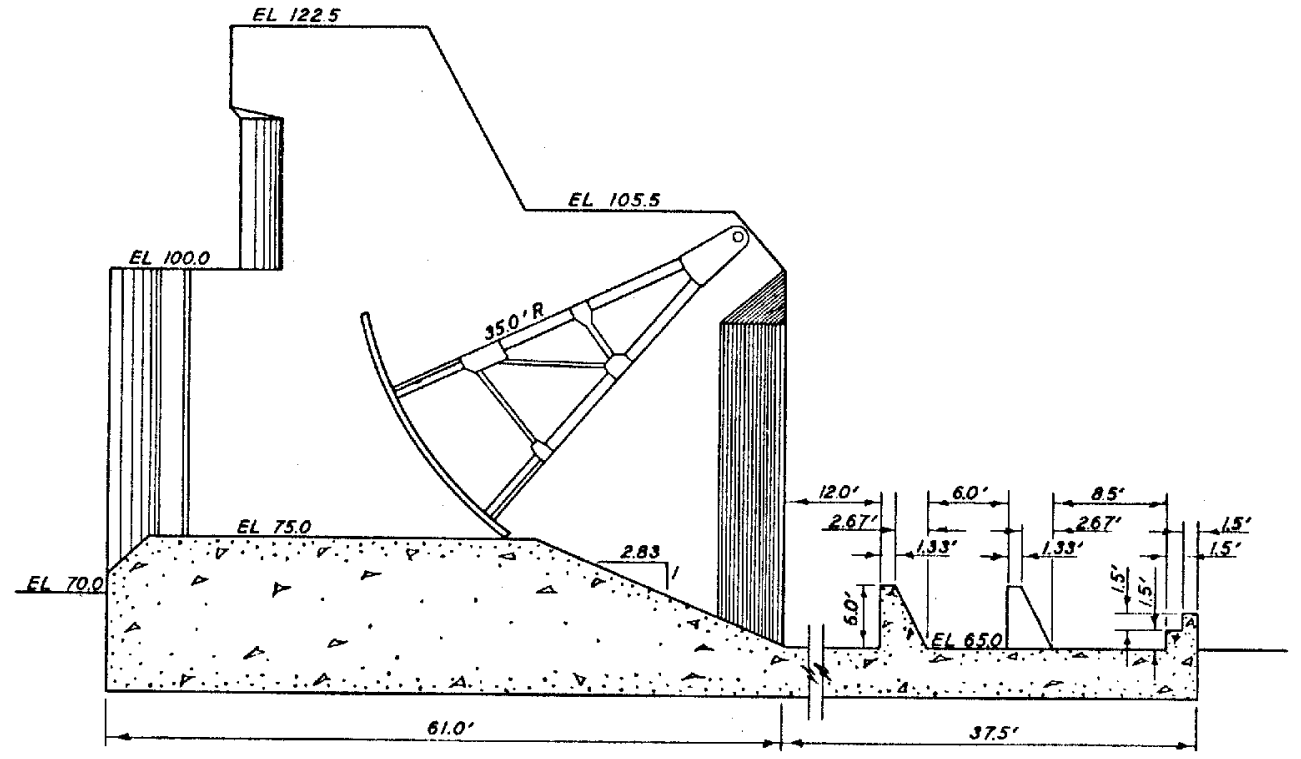

TYPE 22 (RECOMMENDED) DESIGN

NOTE: BAFFLE PIERS ARE G FT WIDE

AND SPACED AT $5.86 \mathrm{FT}$.

Figure 3. Details of stilling basin model tested for Warrior Dam, Warrior River 

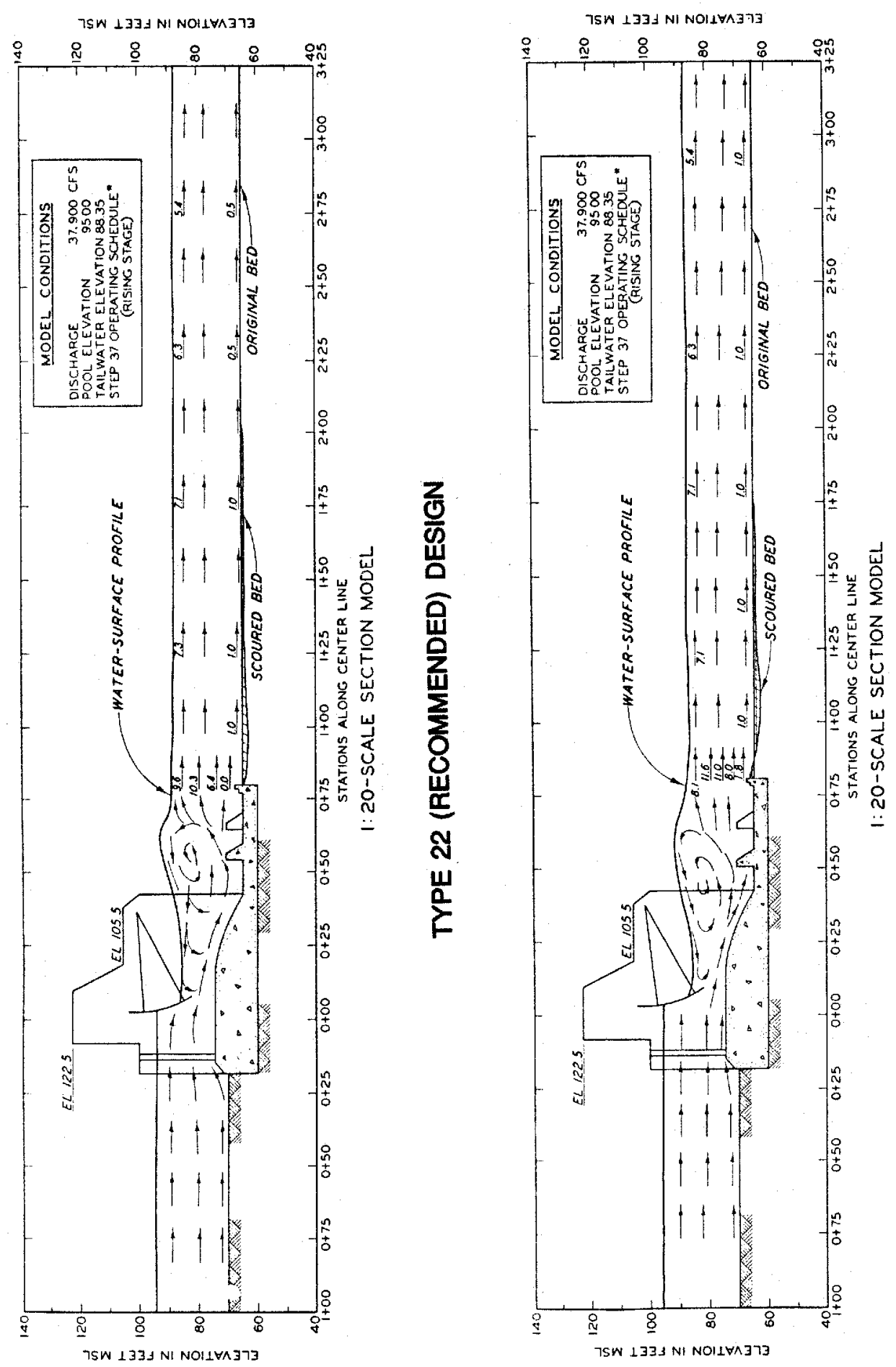

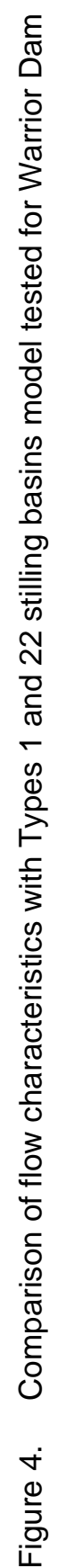




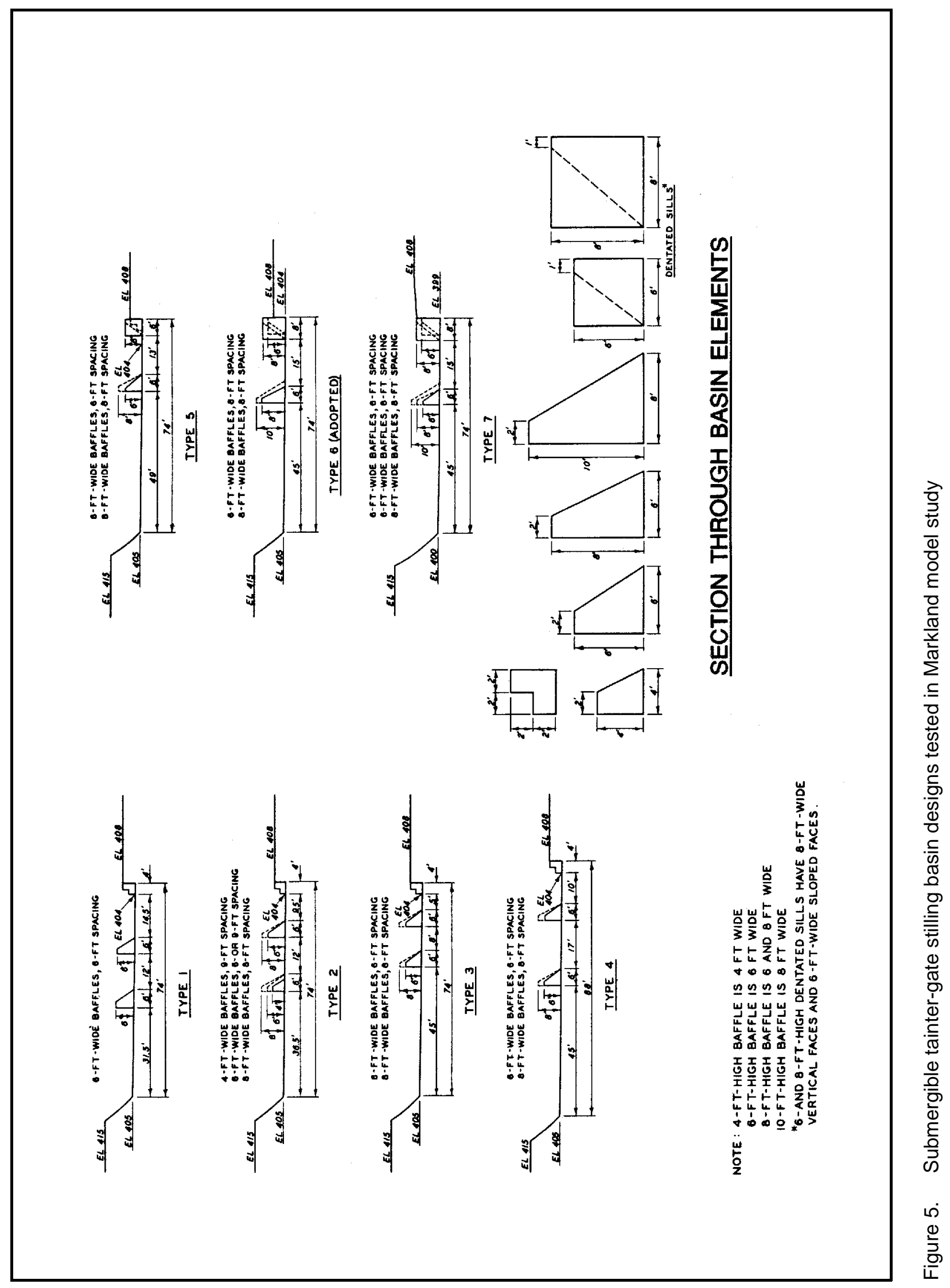


results of the scour tests and the bottom velocities, the Type 6 basin with 8 -fthigh baffles and an 8-ft-high dentated end sill was recommended. The undulating jet action was observed for normal operating conditions with gate openings equal to and greater than $10 \mathrm{ft}$. A stilling basin designed for the nonsubmergible gates of the project incorporated the previous Type 6 design with the Types 2 or 3 gate sill shape shown in Figure 6. The unit discharge for this basin at normal upper pool, all gates open $14 \mathrm{ft}$, and normal tailwater was about $500 \mathrm{cfs} / \mathrm{ft}$.

A model study of Greenup Dam, WES (1961b), revealed that a stilling basin similar to the one at Markland Dam was required. During a model study of New Cumberland Dam, WES (1961c), many stilling basin designs were tested for a submergible gate and gate sill, none of which proved satisfactory. General conclusions from the tests were that basin action depended primarily on head on gate sill, gate opening, drop from gate sill to stilling basin floor, tailwater depth, and position and size of baffles and sills. The shape of the gate sill was very important, but was fixed within narrow limits for a submergible gate; thus satisfactory basin action was hard to achieve. The stilling basin developed for the nonsubmergible gates for this project is shown in Figure 7. The stilling basins were designed to function up to unit discharges of about $235 \mathrm{cfs} / \mathrm{ft}$. It is believed that the gate piers for New Cumberland were extended to the vicinity of the baffle piers. For unit discharges greater than this, open-river-type flow conditions existed. Scour downstream from Markland and New Cumberland dams has been reported, and part of the problem at New Cumberland could possibly be attributed to the undulating jet.

Tests were initiated in 1960, and Grace (1964) reported on model studies conducted on spillways for typical low-head navigation dams to be located on the Arkansas River. Several stilling basin designs were investigated during these studies over a range of pool elevations from 15 to $30 \mathrm{ft}$ above the spillway crest, gate openings from 1 to $14 \mathrm{ft}$, and a tailwater range of $30 \mathrm{ft}$. The unit discharges varied from about 60 to $270 \mathrm{cfs} / \mathrm{ft}$. The stilling basin design recommended from this study is shown in Figure 8. The study revealed that stilling basin performance was affected by the length of the basin and the location of the baffle piers in relation to the toe of the spillway. The report stated that reducing the stilling basin length or placing the baffle piers closer than $35 \mathrm{ft}$ to the toe of the spillway resulted in increased spray action and less energy dissipation.

The riprap and scour tests from the Arkansas River study indicated that a 60 -ft-long basin with one row of 4-ft-high baffle piers located $25 \mathrm{ft}$ upstream from a 4-ft-high, 3-on-4 sloping end sill was the most effective stilling basin for minimum tailwater conditions. The study also revealed that the stability of the riprap protection downstream from the stilling basin was affected by the length of the gate piers. The results indicated that extension of the piers provided greater protection for the riprap for the lesser gate openings and about the same or slightly less protection for the larger gate openings. Comparison of the scour pattern for identical test conditions with the original gate piers and with the gate piers extended to the end of the stilling basin shown in Figure 9 indicate that the scour profiles obtained along the center line of the gate bay and downstream of a gate pier were more uniform with the gate piers extended than those obtained 


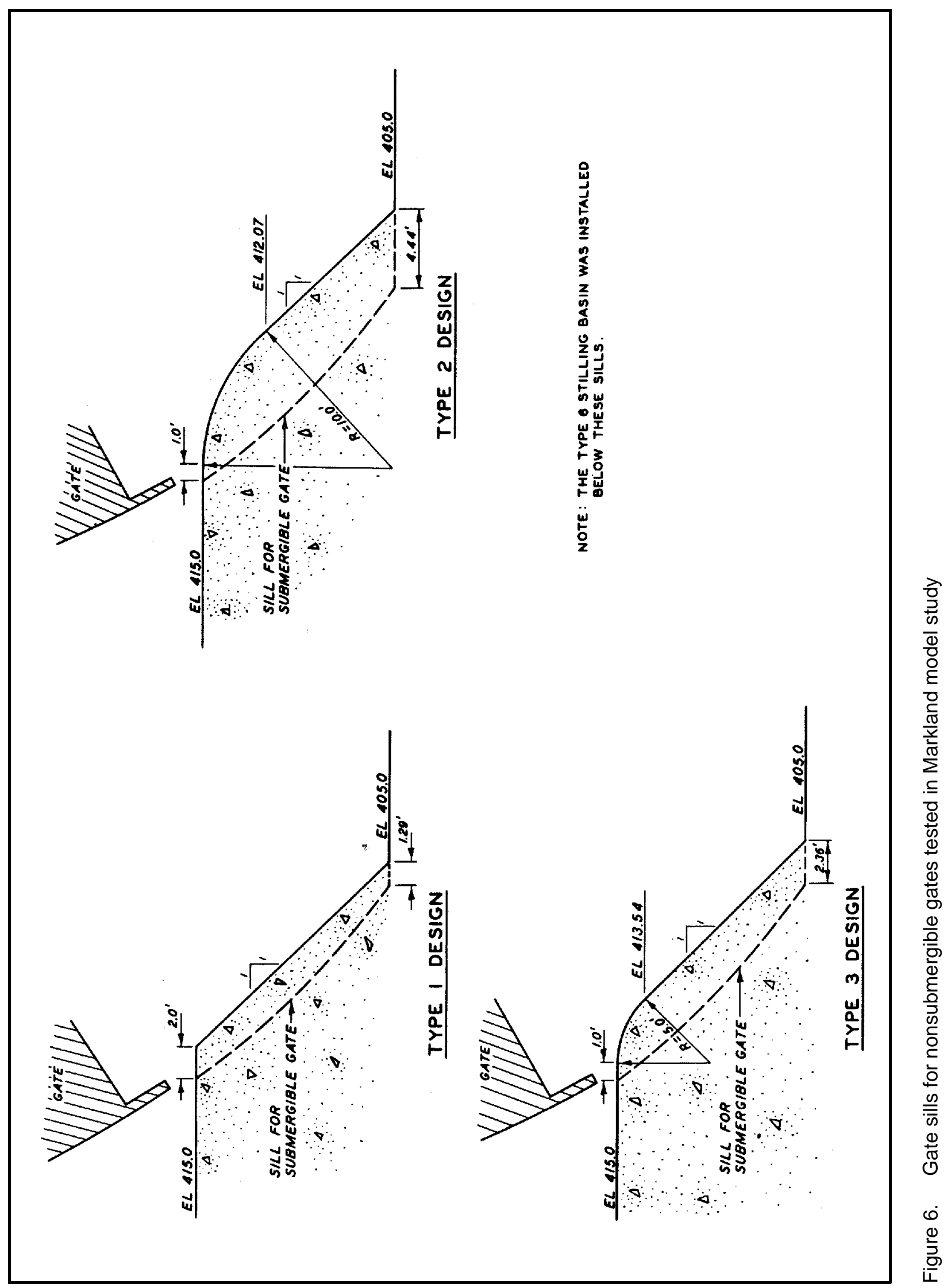




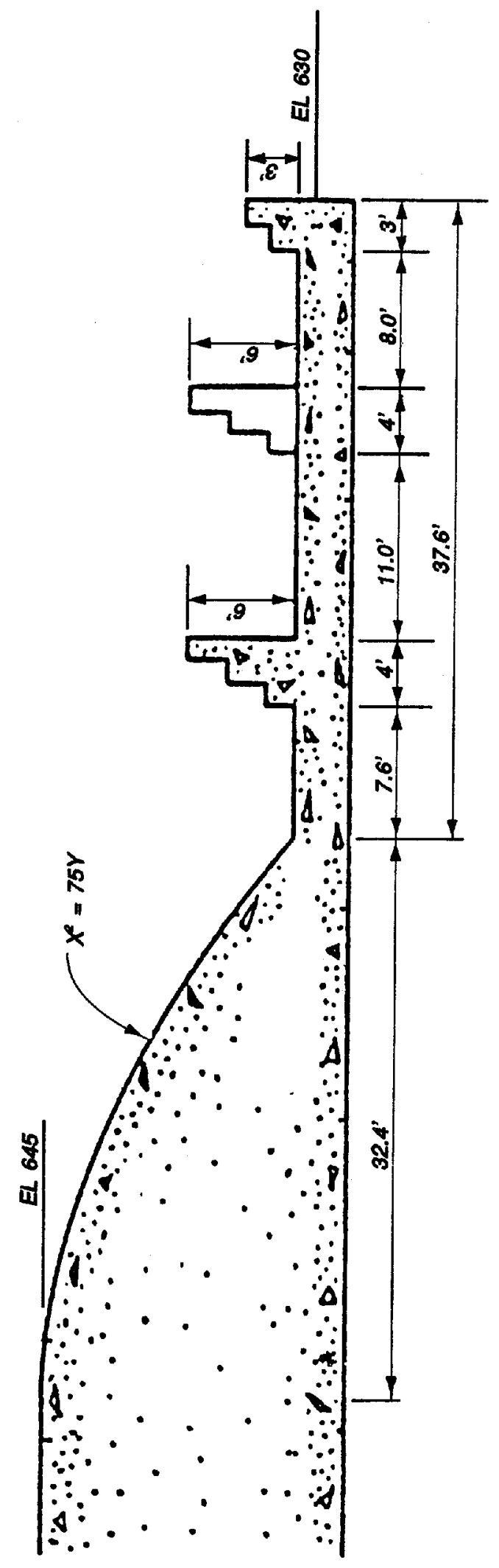

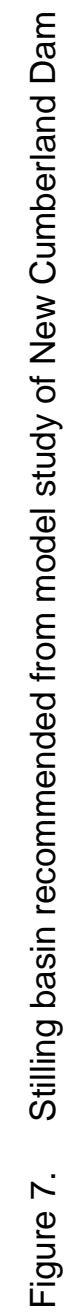




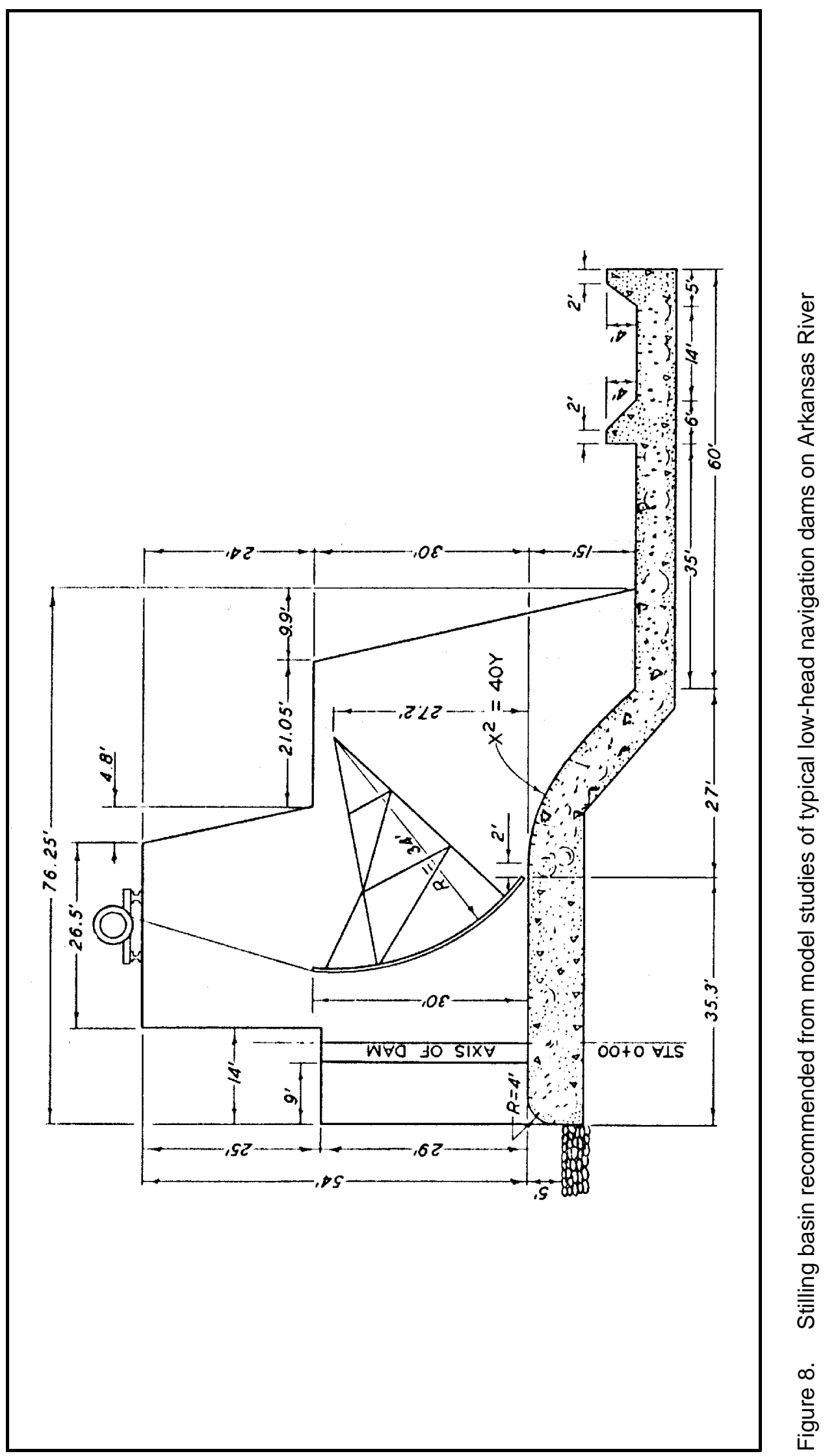




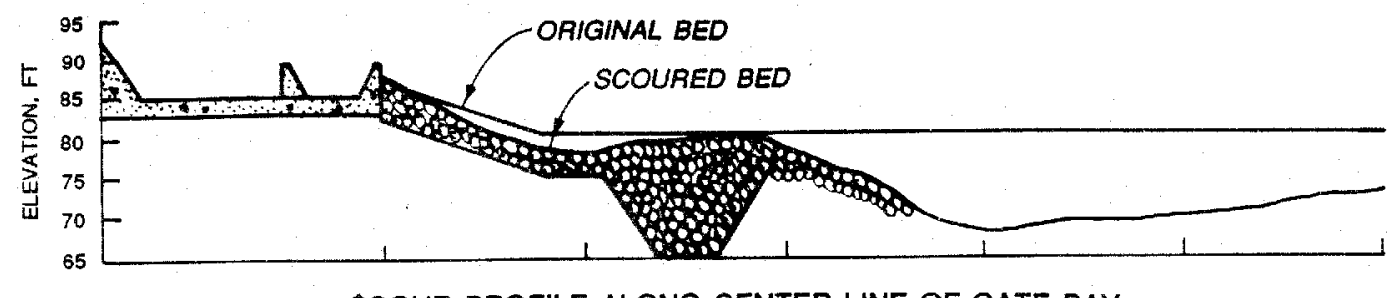

SCOUR PROFILE ALONG CENTER LINE OF GATE BAY

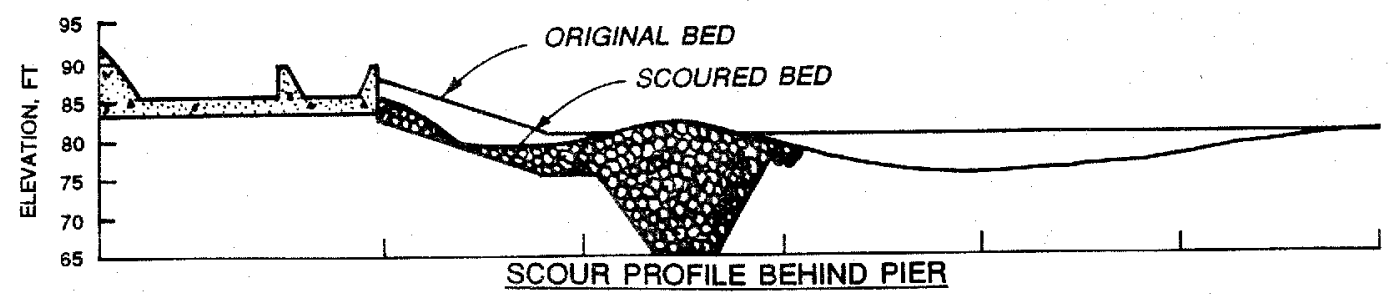

RECOMMENDED DESIGN GATE PIERS (SEE FIGURE 8)
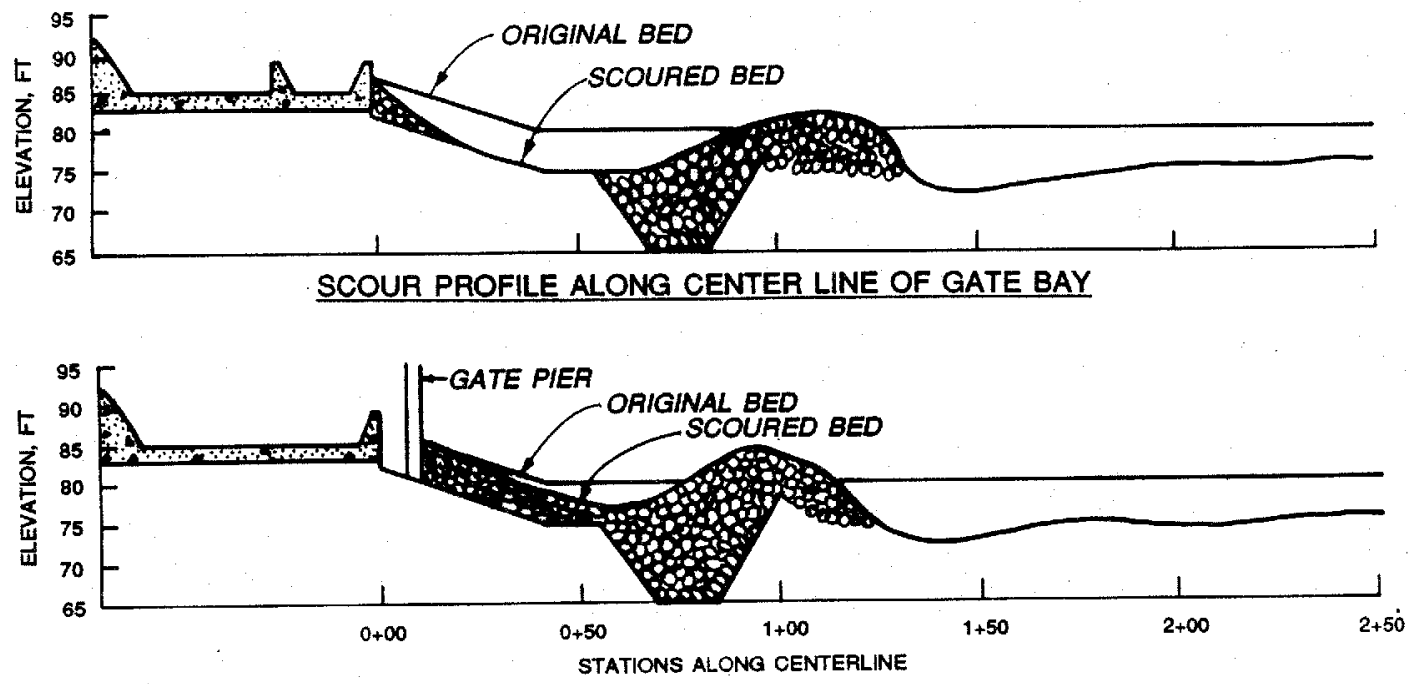

SCOUR PROFILE BEHIND PIER

GATE PIERS EXTENDED TO END SILL

NOTE: EXIT CHANNEL MOLDED IN SAND, ONE ROW 4FT-HIGH BAFFLES WTTH 4-FT-HIGH END SILL
TEST CONDITIONS

$\begin{array}{lc}\text { POO ELEVATION } & 130 \\ \text { TALWWATERT } & 101.5 \\ \text { APRON ELEVATION } & 85 \\ \text { APRON LENGTH } & 60 \text { FT } \\ \text { RIPRAA SIZE } & 36 \text { IN. } \\ \text { GATE OPENING } & 10 \mathrm{FT} .\end{array}$

Figure 9. Comparison of scour patterns for Arkansas River stilling basins model tested 
with the shorter (original design) gate piers. This would indicate a more uniform lateral velocity distribution in the exit channel for lower gate openings with the extended gate piers. Many of the flow conditions observed in this study were severe, but were not as severe as those that would occur if a gate fully opened with minimum tailwater had been tested.

The Arkansas River model tests also showed the undesirable conditions created when an undulating jet forms in the stilling basin as a result of the gate sill shape and relatively large gate openings with accompanying high tailwater. This basin action is shown in Figure 10. The jet is forced to the surface immediately downstream of the gate, then dives through the tailwater, causing high velocities and attack along the channel bottom.

Cummins and Grace (1965) conducted additional model tests for Arkansas River stilling basins. Results from these tests indicated that a short horizontal stilling basin apron terminated by a sloping end sill would produce similar flow conditions but more effective energy dissipation than a roller bucket of comparable dimensions. The roller bucket action in the basin could be changed to a hydraulic jump action by lengthening the basin. Reports to date have indicated that significant scour has occurred downstream from some of the projects on the Arkansas River.

WES (1961d) continued model tests for low-head navigation dams to be located on the Ohio River. A study of Pike Island Dam stilling basin designed based on information from the New Cumberland study revealed that the basin did not function as anticipated for similar project conditions. This was attributed to possible variations in the radius of the spillway gate, trunnion elevation, and shape of the downstream face of the sill. The Type 2 basin shown in Figure 11 was recommended because of the performance of the basin at gate openings greater than $10 \mathrm{ft}$. The gate piers for this stilling basin were extended to the end of the end sill, and the basin was designed for unit discharges up to $250 \mathrm{cfs} / \mathrm{ft}$.

Pickering (1965) reported on a model study of Belleville Dam and was the first Corps study to mention designing the stilling basin for adequate performance during passage of ice and drift with below-normal tailwaters. It was anticipated that one or two gates would have to be opened approximately halfway to accomplish this. The model reproduced one entire gate bay and portions of the adjacent gate bays. The original basin for Belleville is shown in Figure 12 as the Type 1 design, and the recommended basin, shown in Figure 12, is the Type 9 basin. The recommended apron was lowered $3 \mathrm{ft}$ from the original apron elevation to improve basin performance during the passing of ice and drift.

Pickering and Grace (1965) in a model study of Cannelton Dam again revealed that a satisfactory stilling basin for use with a submergible gate was difficult to develop and would require an extremely long basin that was not practical. Therefore, a nonsubmergible spillway gate was recommended. The original basin for this design (Type 1) is shown in Figure 13 along with the Types 2-4, which all functioned similarly and better than the Type 1 for ice and drift passage. 


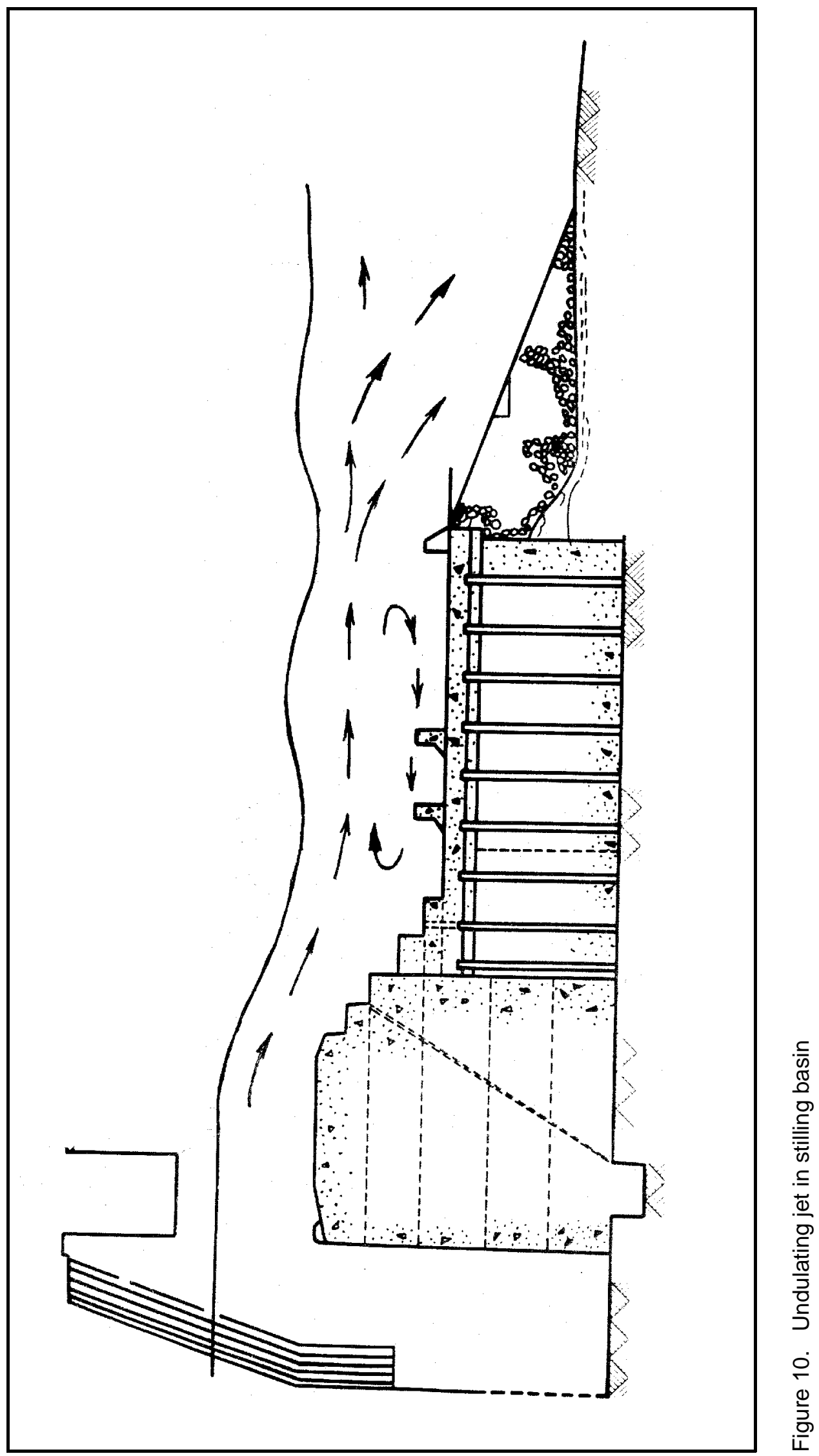



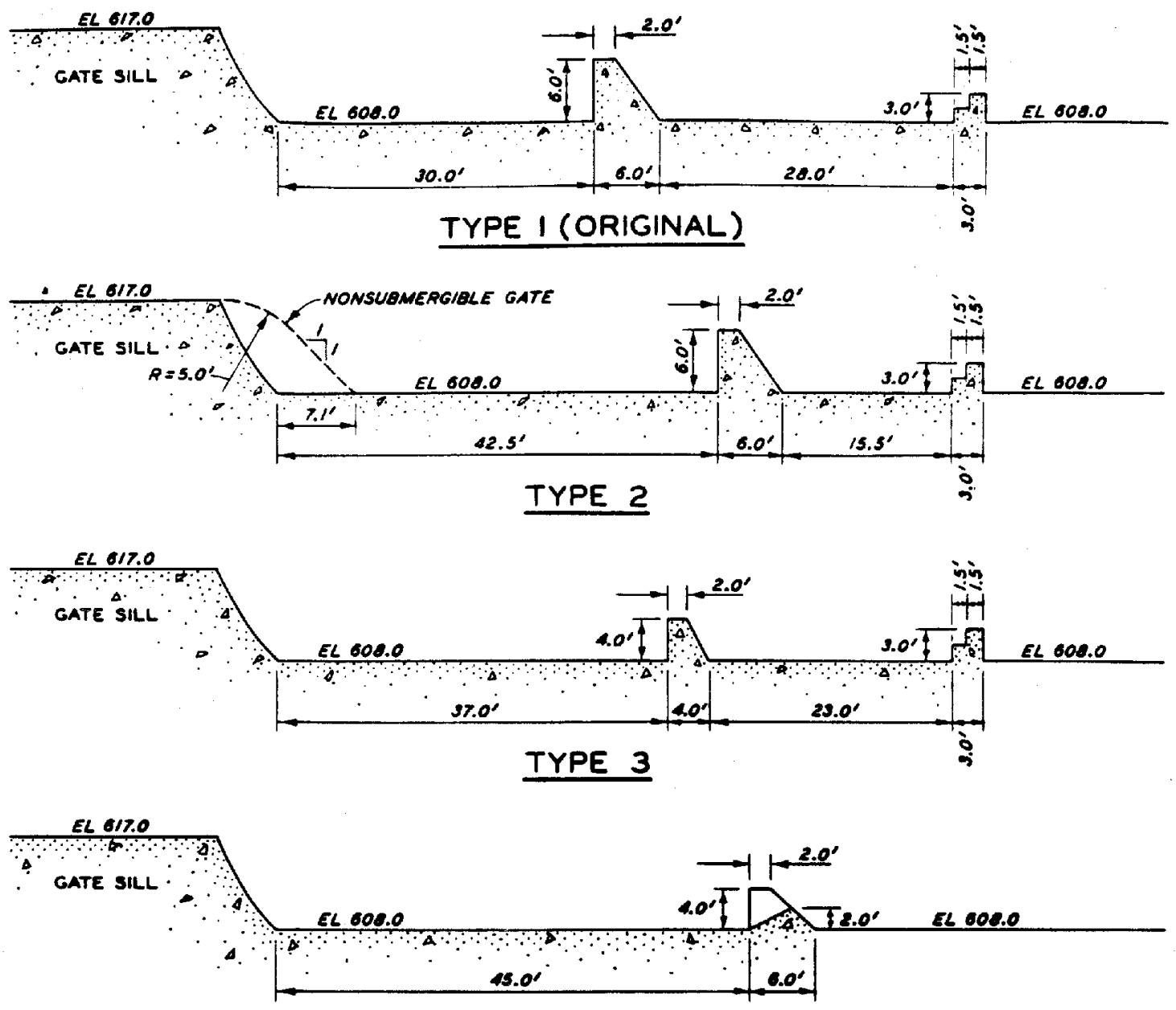

TYPE 4

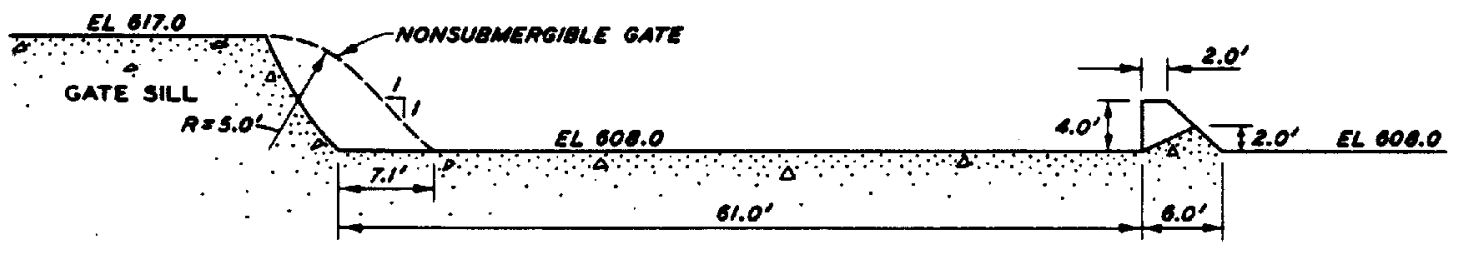

TYPE 5

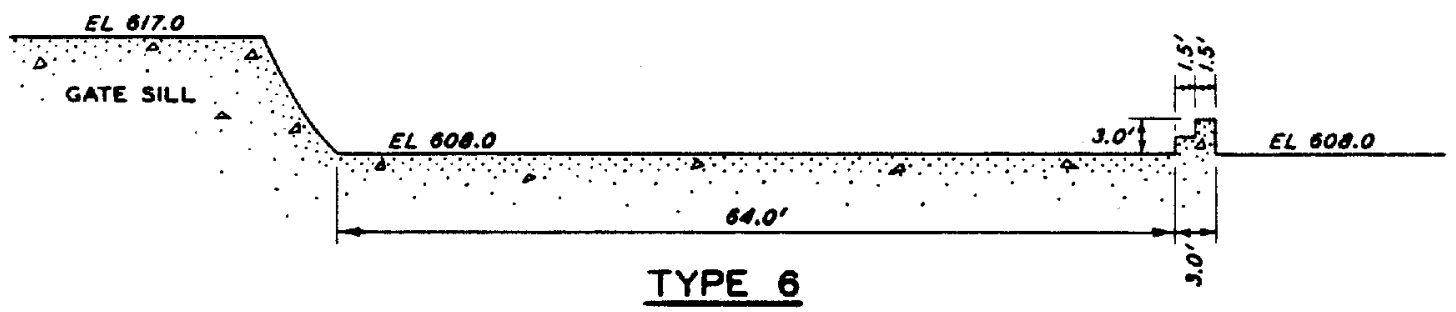

Figure 11. Stilling basin designs tested in model study of Pike Island Dam 


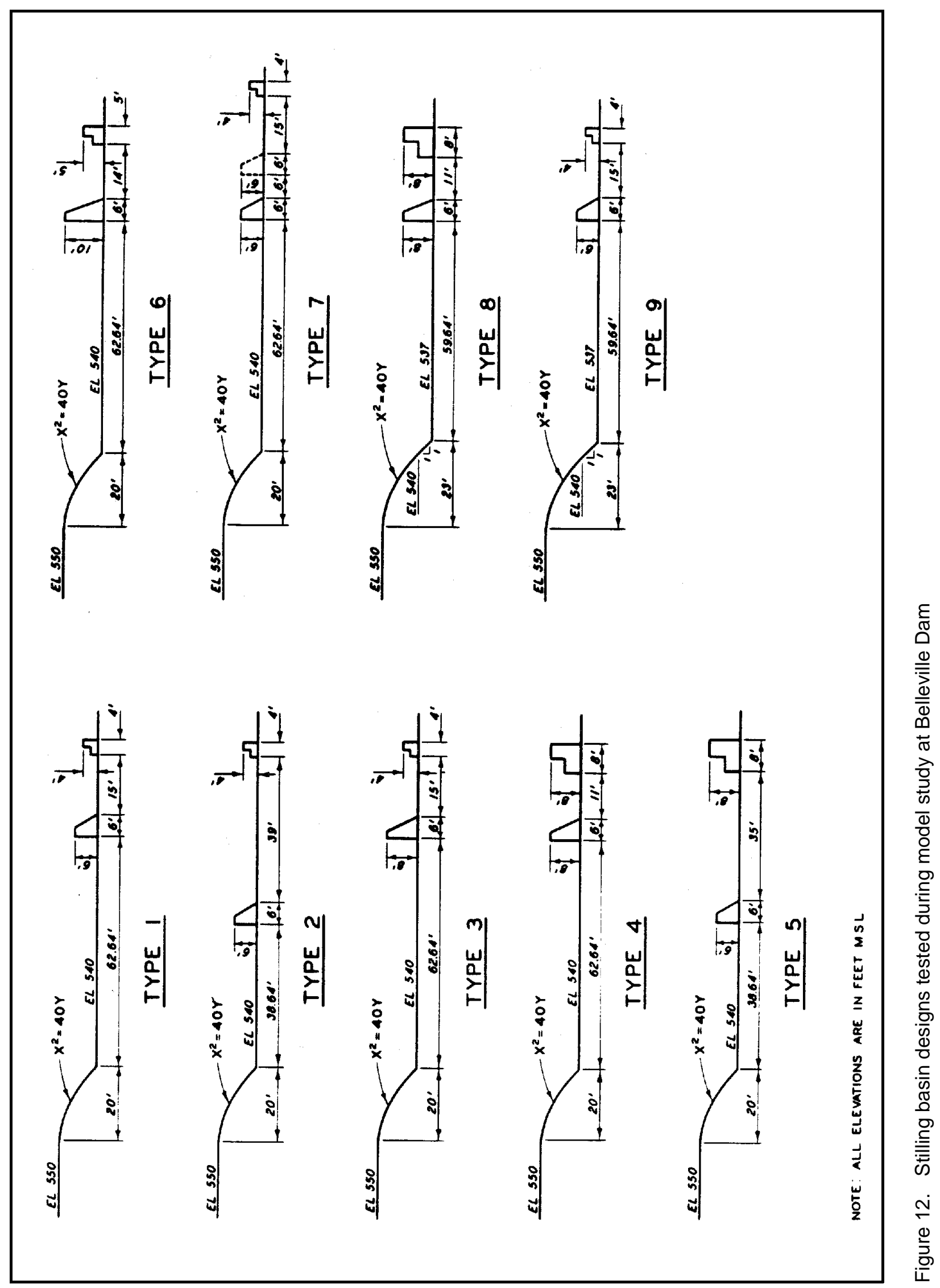




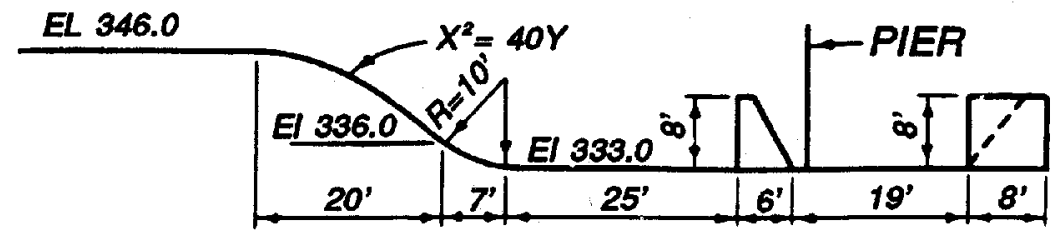

\section{TYPE 1}

$E L 346.0$

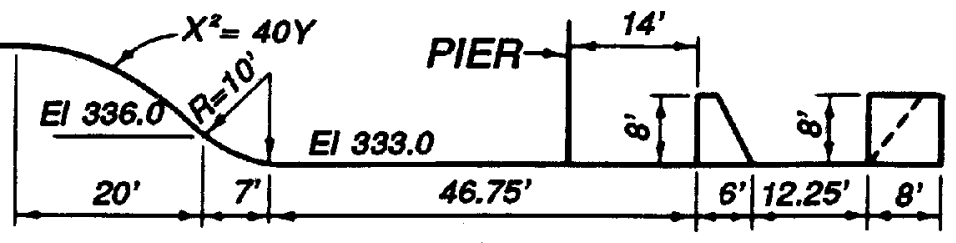

\section{TYPE 2}

EL 346.0

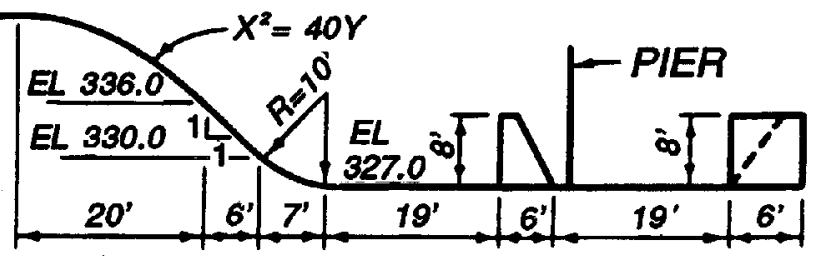

TYPE 3

$E L 346.0$

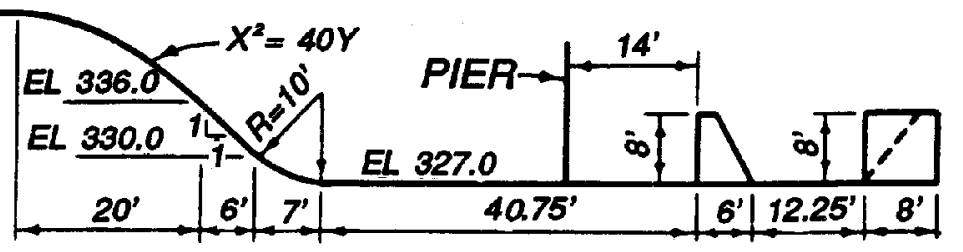

TYPE 4

Figure 13. Stilling basin designs tested during model study at Cannelton Dam 
Pickering (1966), from model tests of a stilling basin for Hannibal Dam on the Ohio River, again found that a lower apron elevation was beneficial in achieving satisfactory basin action for ice and drift passage. Results indicated the Type 3 basin shown in Figure 14 functioned the best; however, the Type 4 was observed to function satisfactorily and would be more economical since the length was shorter.

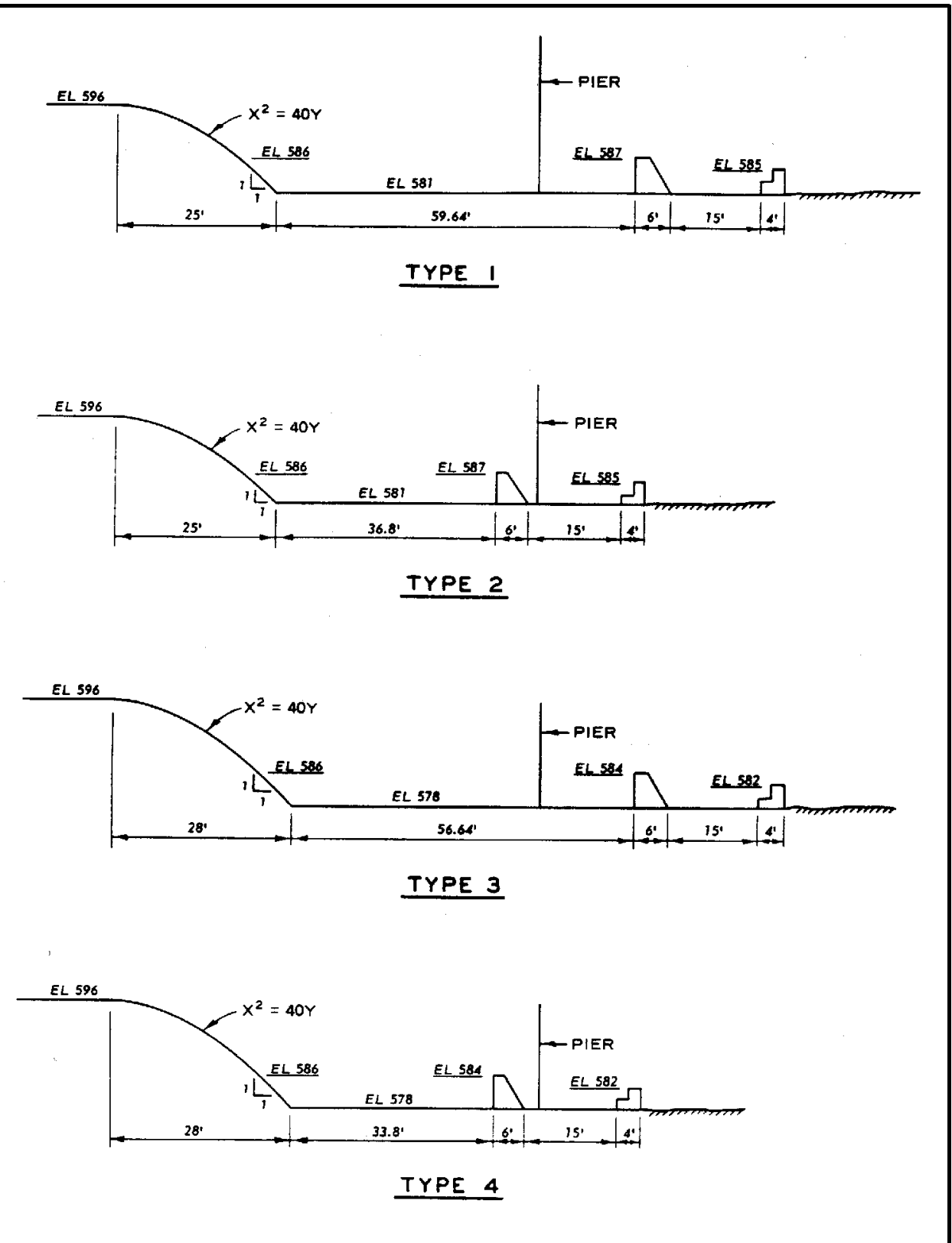

Figure 14. Stilling basin designs tested during model study of Hannibal Dam 
In the 1970s, model studies were conducted in connection with the development of the Tennessee-Tombigee Waterway. During two of these studies, stilling basin designs were investigated. Oswalt (1974), during a study of Aliceville Dam, began the initial tests to develop a low-head navigation dam stilling basin that satisfactorily performed with the normal upper pool, one gate fully open, and minimum project tailwater. This model reproduced the entire gated spillway since the three-dimensional flow patterns were considered important in developing a stilling basin for these flow conditions.

The original design stilling basin from this study is shown in Figure 15. The basin performed adequately for equal gate operations up to $6 \mathrm{ft}$; however, with larger gate openings and operations with a single gate opened one-half or full, a secondary jump formed in the exit channel causing high velocities near the bottom of the channel. The recommended stilling basin from this study is shown in Figure 15. The differences between the original and the recommended design are as follows: addition of a second row of baffle blocks, longer gate piers, longer basin length, apron elevation raised $2 \mathrm{ft}$, and configuration of end sill and exit channel changed. The recommended design provided adequate energy dissipation for both normal and emergency operating conditions. This basin was designed for unit discharges up to $350 \mathrm{cfs} / \mathrm{ft}$.

Oswalt and Pickering (1974) developed stilling basins for Columbus Dam for operations with normal upper pool and minimum tailwater for one gate one-half open and one gate fully open. The original design basin along with the recommended basins developed for the two conditions mentioned are shown in Figure 16. To achieve adequate basin performance for conditions with normal upper pool, one gate fully open, and minimum tailwater, the apron elevation had to be lowered, and the configuration of the exit channel changed. This basin was designed for unit discharges up to $350 \mathrm{cfs} / \mathrm{ft}$.

A model study of the replacement structure for Lock and Dam 26 on the Mississippi River was conducted by Oswalt and Pickering (1973). The stilling basin design for this project was investigated and was developed for flow conditions with normal upper pool, one gate fully open, and minimum tailwater. The original basin shown in Figure 17 performed satisfactorily for gate openings up to $22 \mathrm{ft}$ with minimum tailwater, but with one gate opened full, the jump swept out of the basin and caused high velocities in the downstream channel. The Type 16 basin shown in Figure 17 produced desirable flow conditions for the emergency operations reproduced with normal upper pool, one gate fully open, and minimum tailwater. Flow conditions were observed with the length of the gate piers, which varied from 26 to $41 \mathrm{ft}$. Results showed that the shorter pier lengths ( $26 \mathrm{ft}$ ) allowed excessive return flow into each side of the basin and concentrated the flow toward the center of the bay. When the piers were extended far enough to eliminate all the return flow, a weak jump formed, and the toe of the jump moved farther downstream. The optimum length was found to be $36 \mathrm{ft}$. For economical reasons, a basin was designed for a gate opened sufficiently to pass ice and drift. This basin shown in Figure 17 had a 6-ft higher basin apron than the recommended design. The basin for one gate opened full was 


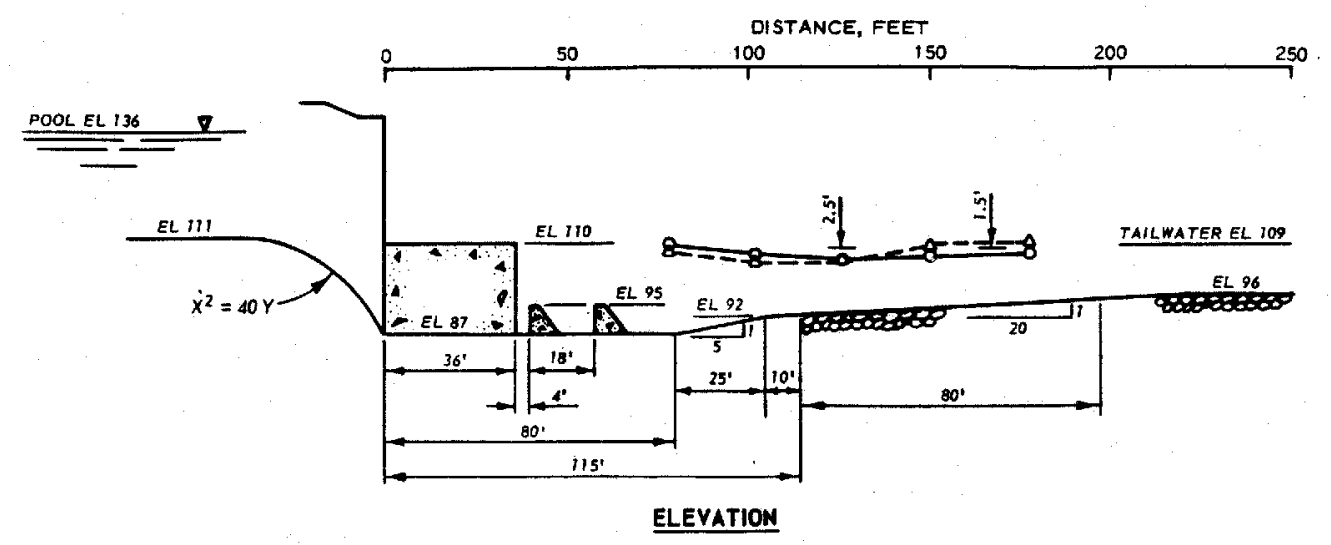

TYPE 6 (RECOMMENDED) DESIGN

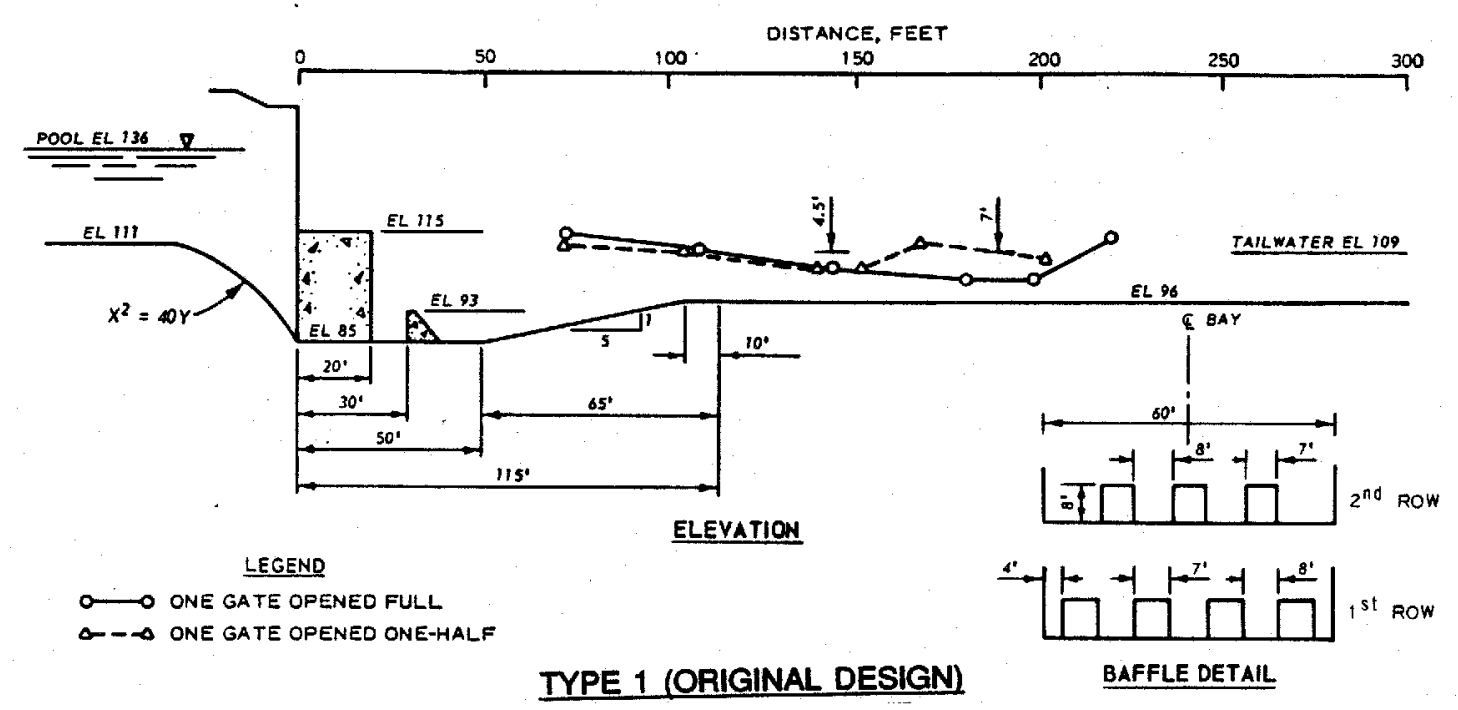

Figure 15. Stilling basins model tested during study of Aliceville Dam

developed for unit discharges up to $775 \mathrm{cfs} / \mathrm{ft}$, and the basin for ice and debris passage (13-ft gate opening) was developed for unit discharges up to $382 \mathrm{cfs} / \mathrm{ft}$.

The development of the Red River Waterway resulted in model studies of the navigation dams to be located on this river. Oswalt (1977) reported on the first of these studies for Red River Lock and Dam No. 1. Stilling basins were developed for single-gate operations with three spillway crest elevations. Basin action with the highest spillway crest was the best, and stilling basin designs were developed with this spillway elevation for the following conditions

a. Normal upper pool (elevation 40), minimum tailwater (elevation 4.0), and one gate approximately one-half open to permit passage of debris. 


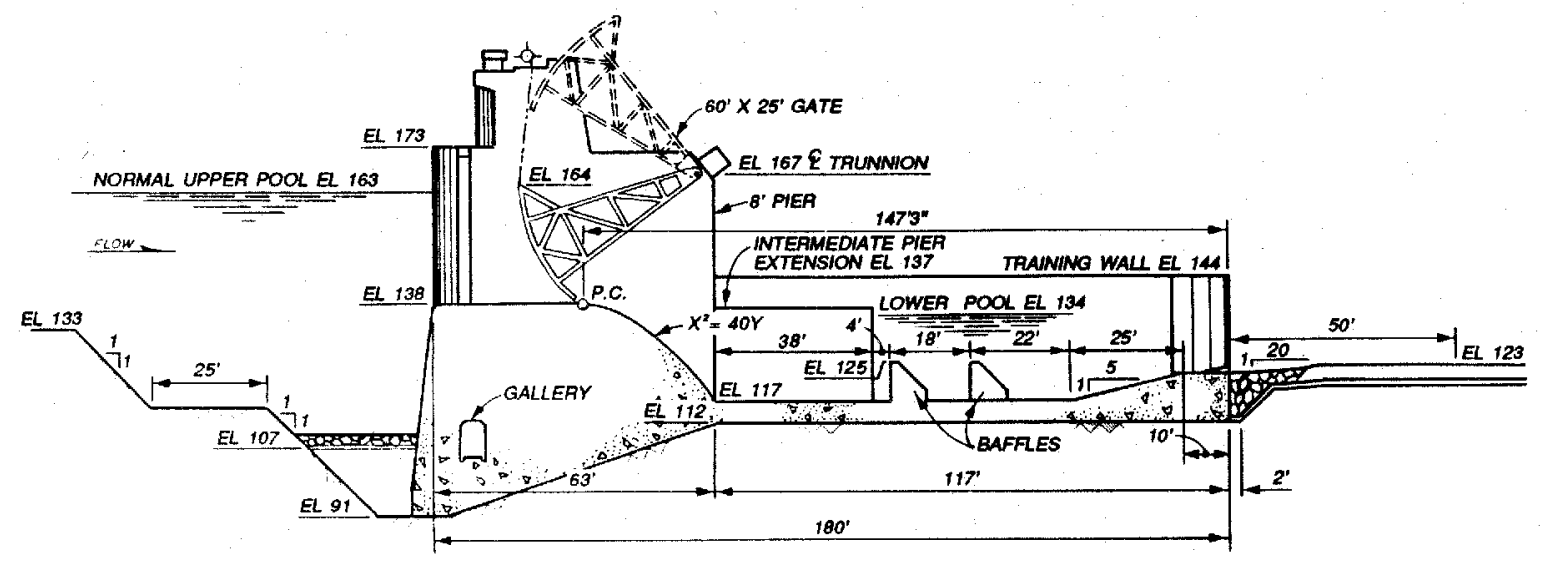

SPILLWAY SECTION

ORIGINAL DESIGN

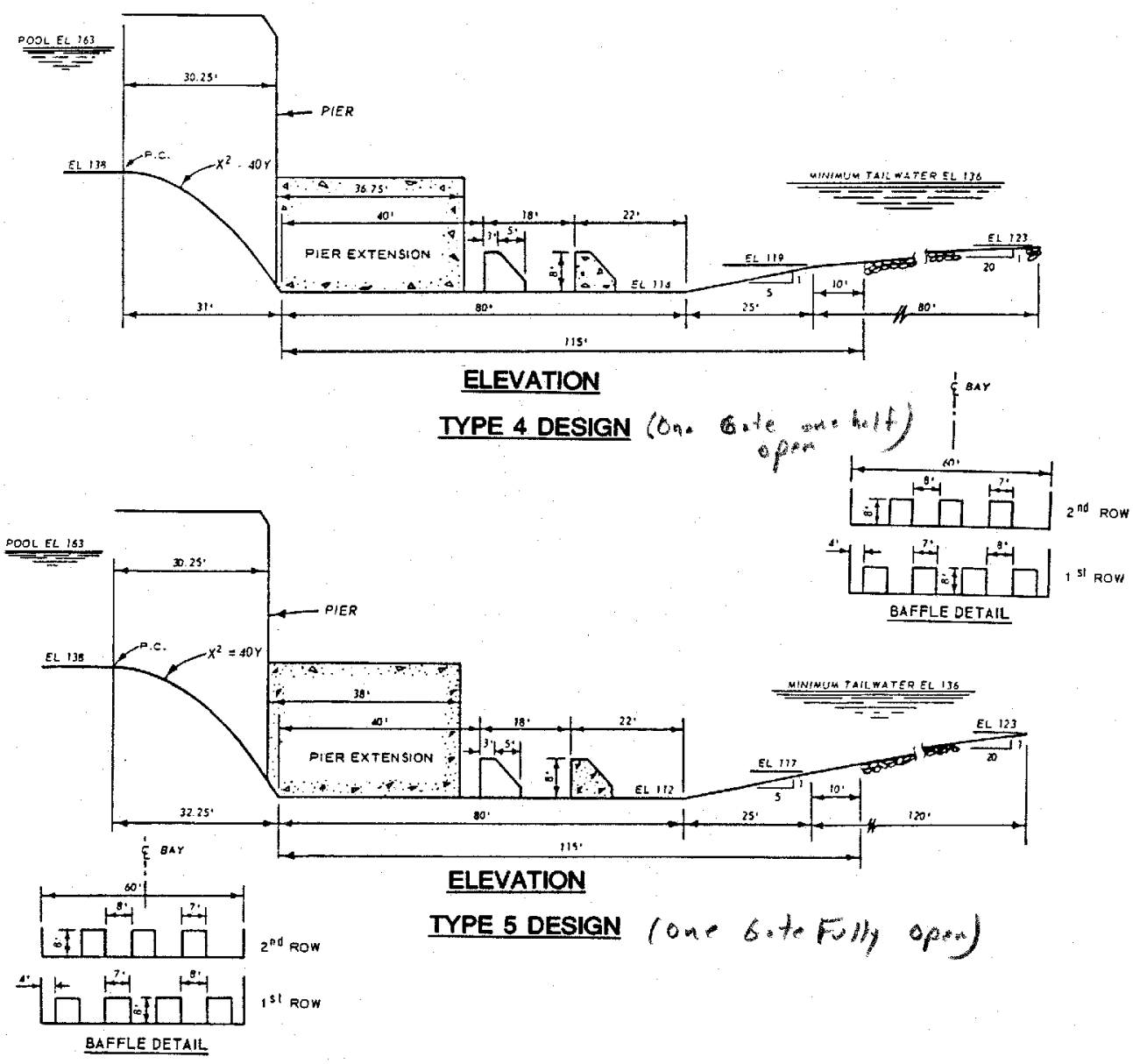

Figure 16. Stilling basins model tested during study of Columbus Dam 


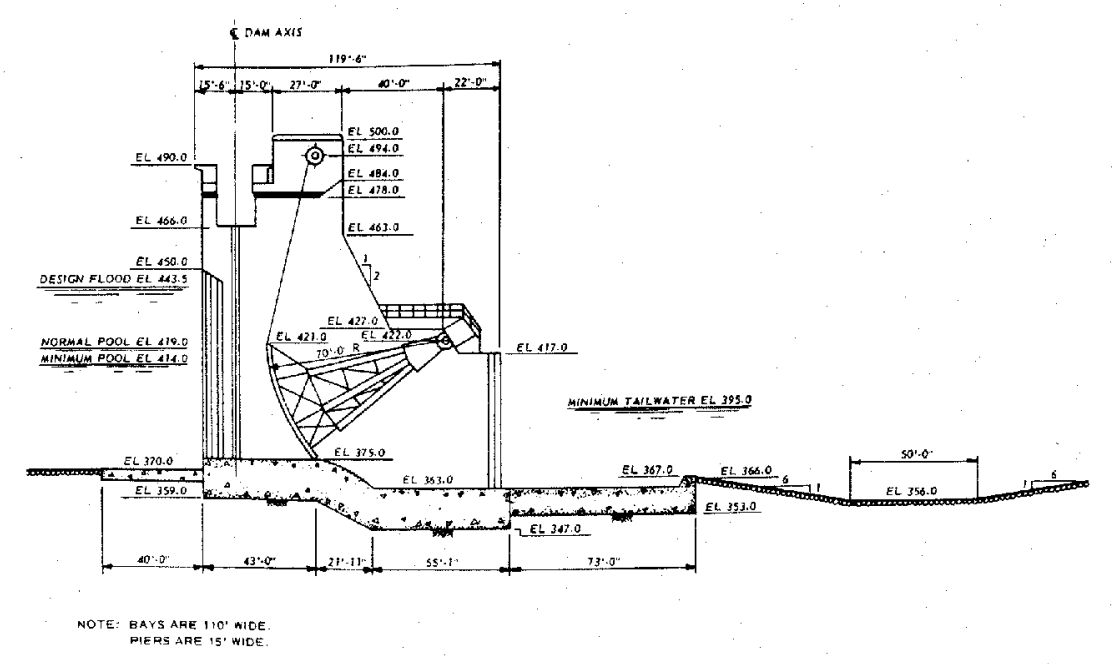

TYPE 1 (OAIGINAL DESISN)
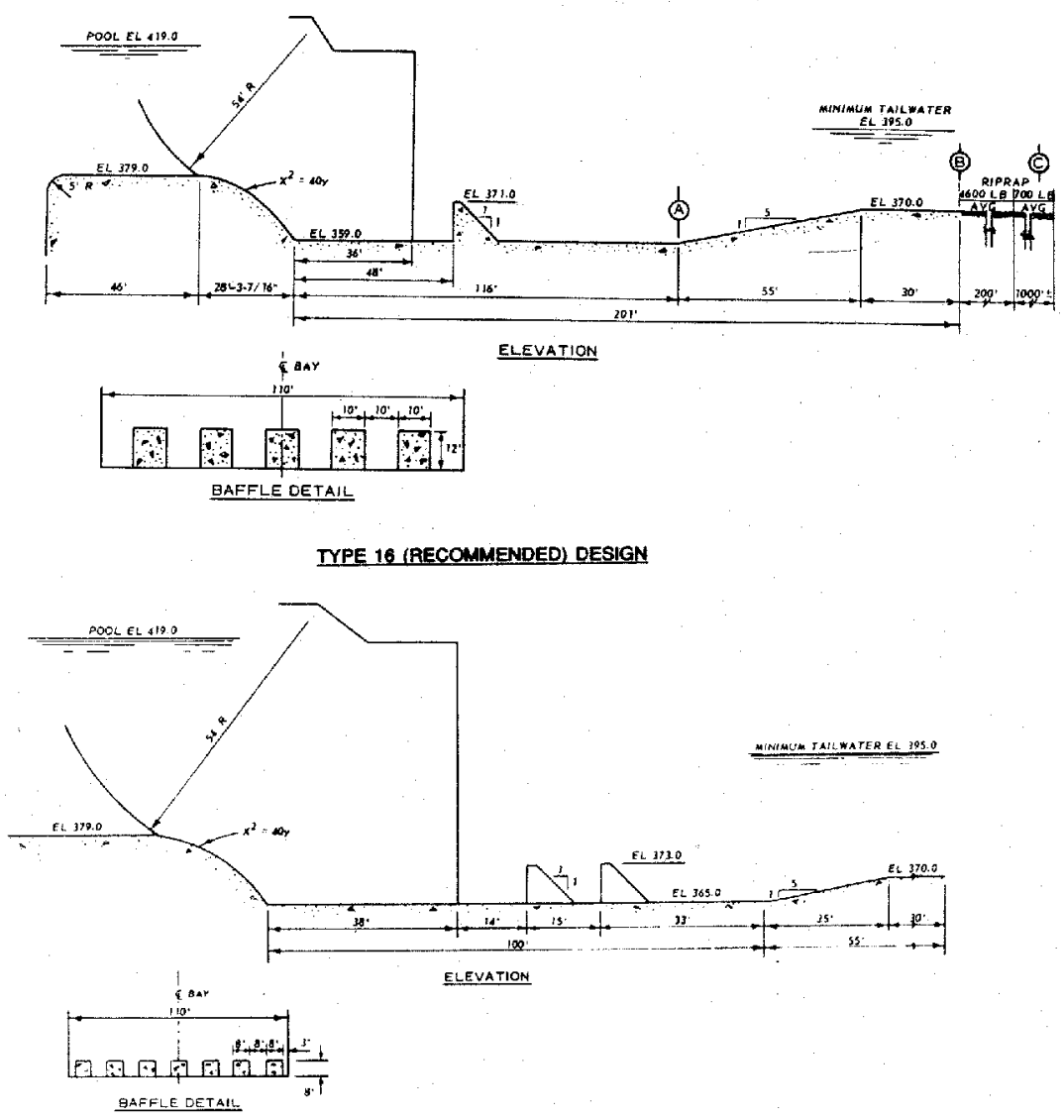

TYPE 3O DESIGN FOR ICE AND DRIFT PASSAGE

Figure 17. Stilling basins tested during model study of Lock and Dam No. 26 
$b$. Conditions the same as those in subparagraph $a$, except with a tailwater elevation of 10.0, which is expected 98 percent of the time.

c. Normal upper pool and minimum tailwater with one gate fully open; this condition should occur only during an emergency or misoperation of the gate.

d. Conditions the same as those in subparagraph $c$, except with a tailwater elevation of 10.0, which is expected 98 percent of the time.

Each of the basins were developed to provide adequate energy dissipation for single-gated flows and prevent maximum bottom velocities from exceeding $15 \mathrm{fps}$ downstream of the basin. The Type 7 stilling basin shown in Figure 18 was developed for conditions $a$ and $d$; the Type 17 stilling basin in Figure 18 for condition $b$; and the Type 16 stilling basin in Figure 18 for condition $c$. The Type 16 basin consisted of the lowest apron elevation and the longest basin as expected. These basins were developed for the following unit discharges:

Type 16, $484 \mathrm{cfs} / \mathrm{ft}$, Types 17 and 7, $370 \mathrm{cfs} / \mathrm{ft}$. All gate pier extensions were $45 \mathrm{ft}$ long.

Maynord and Markussen (1989) developed a stilling basin for John H. Overton Lock and Dam (Red River No. 2) that would function for the following conditions

Condition

Normal gate openings normal pools

One gate half open normal upper pool, minimum lower pool, el $50 \mathrm{ft}$

One gate half open normal upper pool, minimum lower pool, el $40 \mathrm{ft}$

One gate full open normal upper pool, lower pool, el $46 \mathrm{ft}$

One gate full open normal upper pool, minimum lower pool, el $40 \mathrm{ft}$
Performance

Good energy dissipation no standing waves

Good energy dissipation occasional standing waves

Some standing waves and minor riprap damage allowable - project integrity not threatened

Occasional standing waves and riprap blanket movement - minor damage allowable but project integrity must be maintained

Some standing waves and riprap blanket movement minor damage allowable but project integrity not threatened 


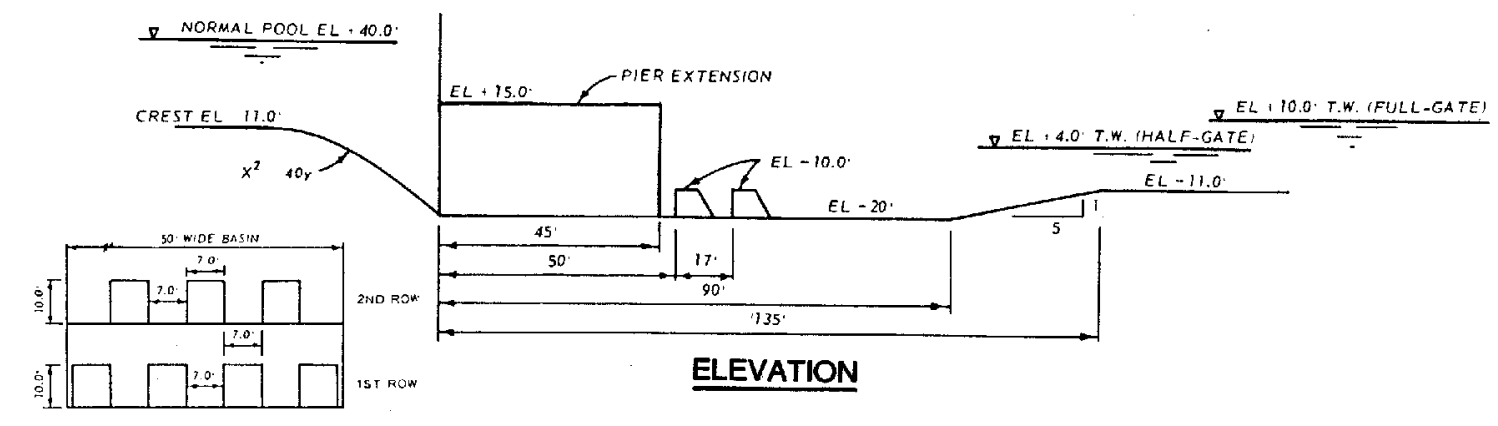

BAFFLE DETAIL

TYPE 7 DESIGN

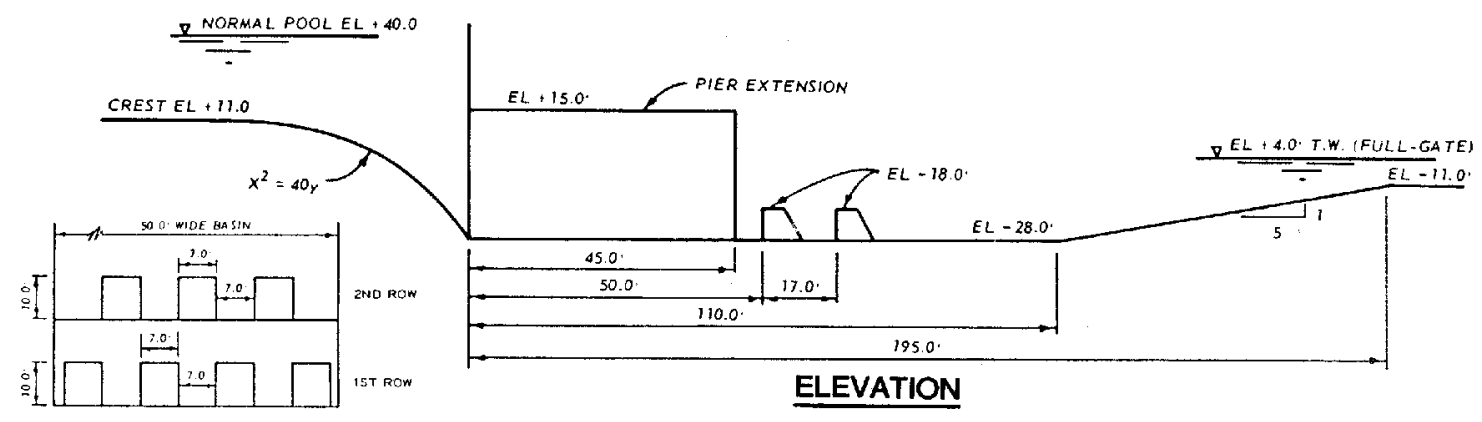

BAFFLE DETAIL

TYPE 16 DESIGN

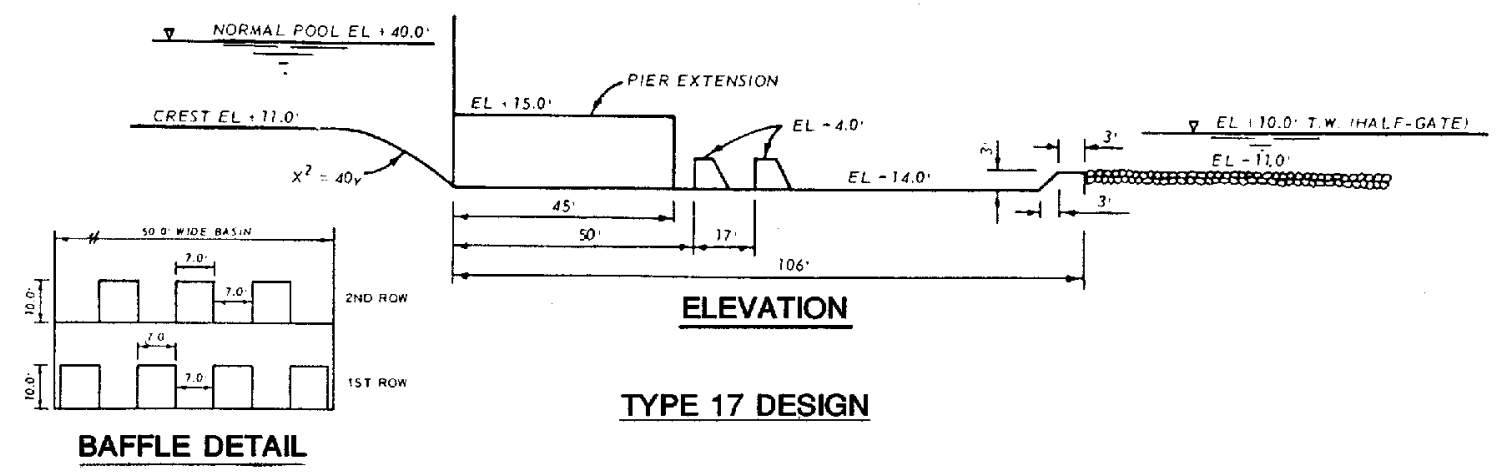

Figure 18. Stilling basins model tested during study of Red River Lock and Dam No. 1

Also the stilling basin apron could be no lower than elevation 12. The Type 1 basin shown in Figure 19 did not provide good energy dissipation, and considerable damage to the riprap protection occurred. The recommended design, Type 13 design shown in Figure 19, provided satisfactory performance for the single-gate emergency operating conditions. This basin functioned for unit discharges up to $667 \mathrm{cfs} / \mathrm{ft}$. 


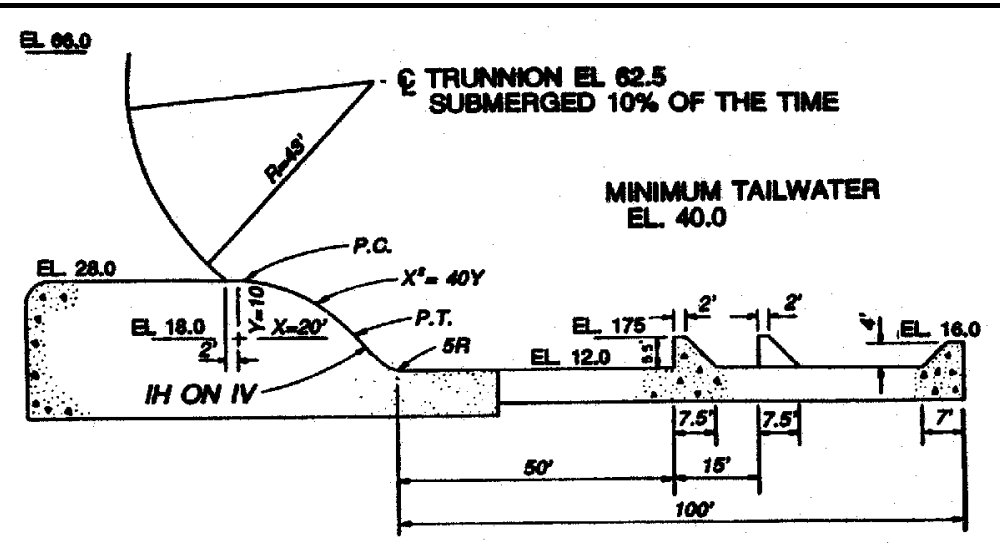

TYPE 1 (ORIGINAL DESIGN)

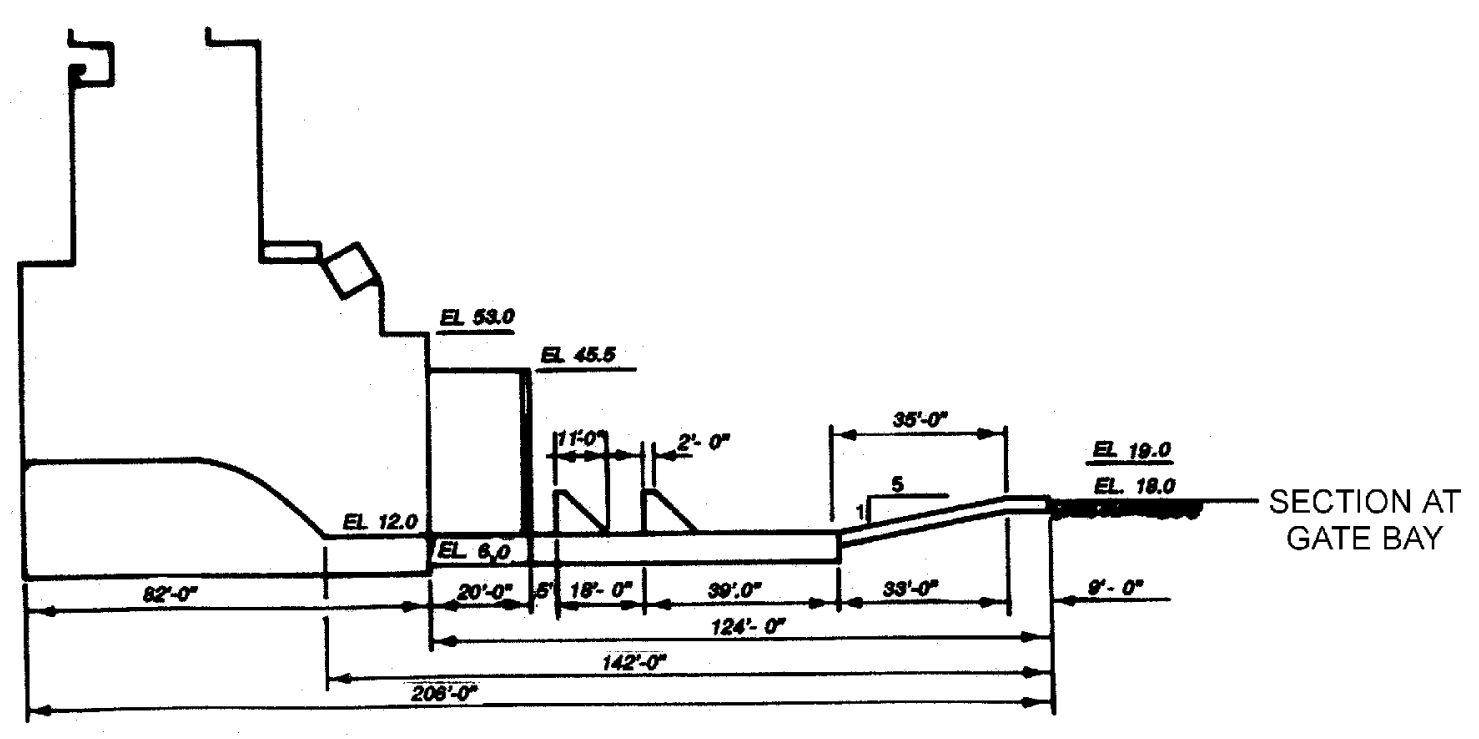

TYPE 13 DESIGN STILLING

Figure 19. Stilling basins model tested during study of John H. Overton Dam (Red River No. 2)

Maynord (1991) developed a stilling basin suitable for emergency operations for unit discharges up to $817 \mathrm{cfs} / \mathrm{ft}$ for Red River No. 3. Leech (1990) also developed a stilling basin for Red River No. 4 suitable for emergency operations.

In the early 1980s, a series of site-specific model studies were conducted for the Pittsburgh District to determine methods to repair scour damage downstream from the stilling basins of various projects. Stilling basin performance was observed for different flow conditions during these studies. Hite (1982) conducted a model study for Emsworth Dam on the Ohio River. Tests results indicated that severe flow conditions existed with normal upper pool and any gate opening if minimum tailwater was present. A gate operation schedule based on the tailwater elevation was developed along with a protective stone blanket downstream from 
the dam that consisted of 4- to 5-ft-diam stones. The report recommended that protection be more substantial if ice and debris had to be passed when the tailwater was minimum. The stilling basin for this project is shown in Figure 2.

Hite (1984) conducted a model study of Montgomery Dam on the Ohio River and found the stilling basin functioned satisfactorily for emergency operating conditions (normal upper pool, one gate fully open, and minimum tailwater) and a scour protection material consisting of a 36-in. riprap would adequately protect the downstream area during this operation. The stilling basin for this project is shown Figure 20. Hite (1987) conducted a model study of Pike Island Dam to determine scour protection for the area downstream from the stilling basin. The stilling basin for this project was originally designed for equal gate operations as discussed earlier. Scour protection consisting of 5- to 6-ft-diam stones placed on a $1 \mathrm{~V}$ on $3 \mathrm{H}$ downward slope was developed for flow conditions with normal upper pool, a 10-ft gate opening, and minimum tailwater. These flow conditions were equivalent to a unit discharge of $248 \mathrm{cfs} / \mathrm{ft}$. Construction of the original prototype stilling basin is shown Figure 21.

A model study of Morgantown Dam by Hite (1989) was conducted to determine a suitable scour protection design. The study demonstrated that a secondary stilling basin adjoining the original basin could be developed for emergency operating conditions. This basin shown in Figure 22 was designed from guidance in EM 1110-2-1605 (USACE 1987). This basin functioned for unit discharges up to $160 \mathrm{cfs} / \mathrm{ft}$.

Hite (1993) conducted a model study of Dam No. 2 on the Arkansas River (presently Wilbur D. Mills Dam) to develop a scour protection design for emergency conditions. Again, a secondary stilling basin was developed to function for conditions with normal upper pool, one gate fully open, and minimum projected tailwater. This basin is shown in Figure 23, and basin action was adequate for unit discharges up to $485 \mathrm{cfs} / \mathrm{ft}$. Further tests indicated it was feasible to develop a secondary stilling basin from grouted riprap placed in sunken barges for emergency operating conditions as shown in Figure 24. A navigation accident that occurred at Dam No. 2 Arkansas River in December of 1982 is shown in Figure 25 and illustrates how gate operations can be severely affected by navigation accidents. Only 3 of the 16 gates were fully operational immediately following this accident.

Research investigations concerning scour downstream from gated low-head navigation dams were conducted by Hite (1988a) under the Repair, Evaluation, Maintenance, and Rehabilitation (REMR) research program and verified portions of the stilling basin design procedure presented in EM 1110-2-1605. This basin was designed for adequate energy dissipation with normal upper pool, one gate fully open, and minimum tailwater. Details of the basin are shown in Figure 26, and a photograph of the 1:25-scale model used during the investigation is shown in Figure 27. The main purpose of the investigation was to determine the stability of the downstream scour protection, which is certainly dependent on the 


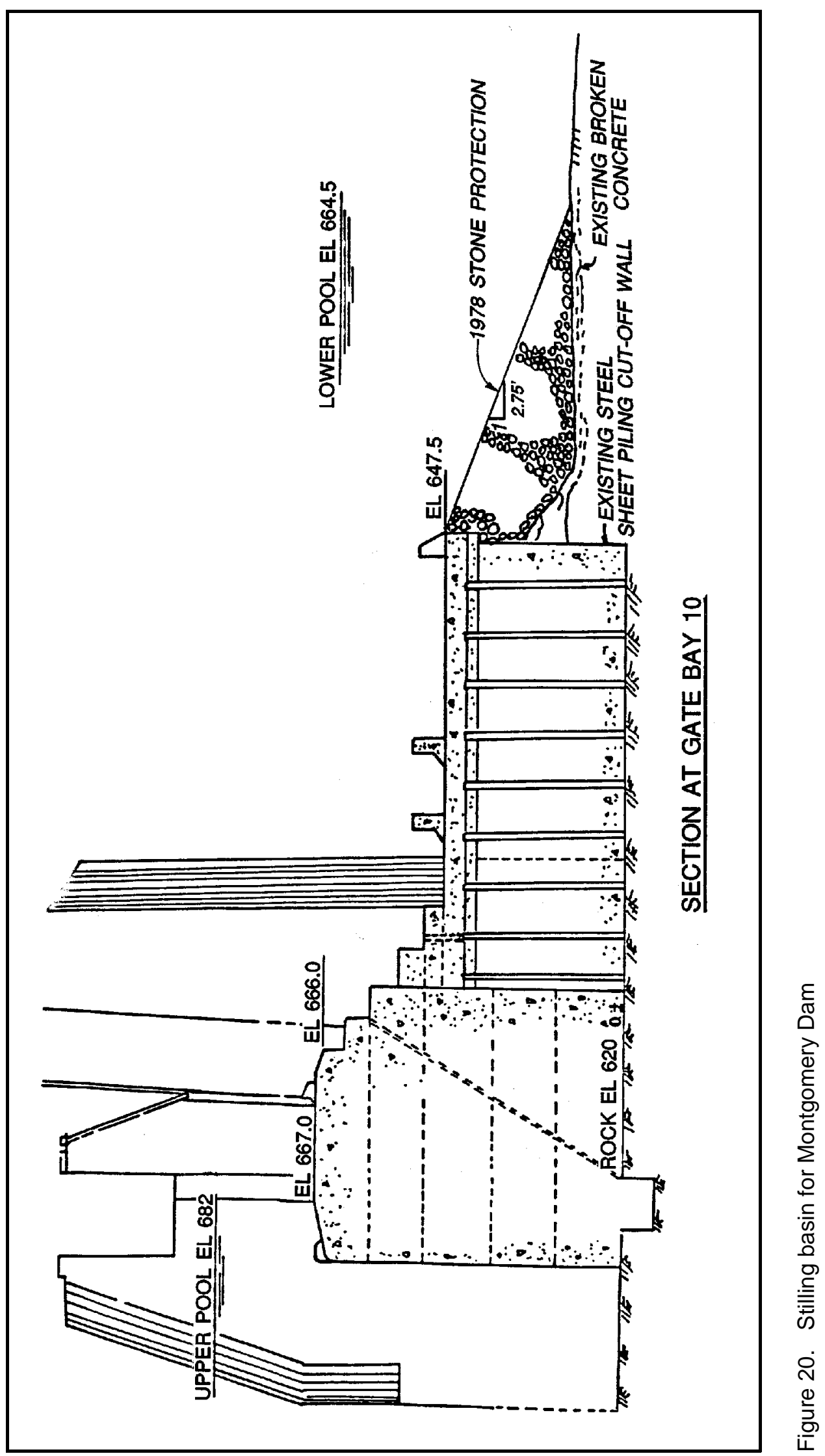




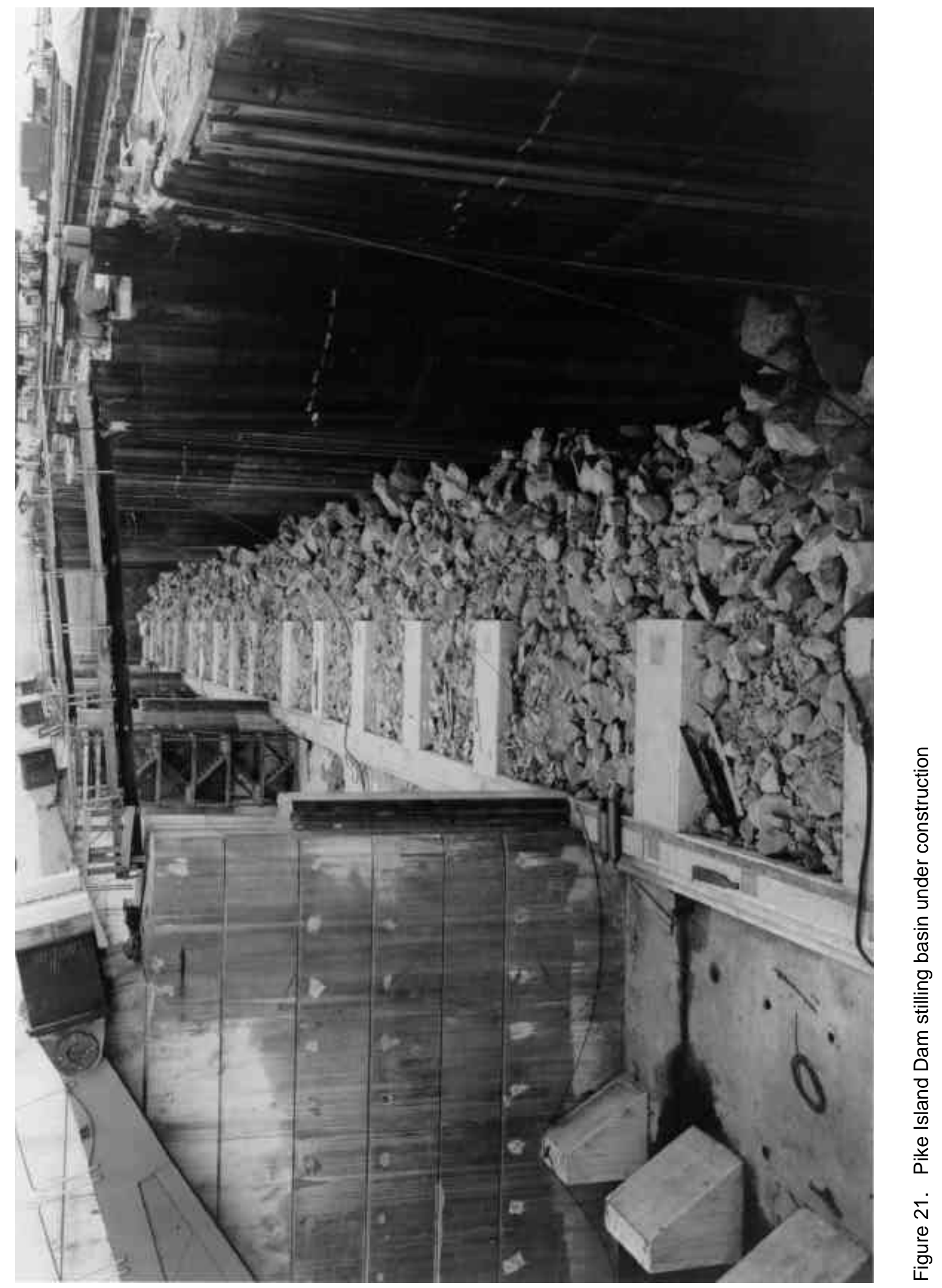




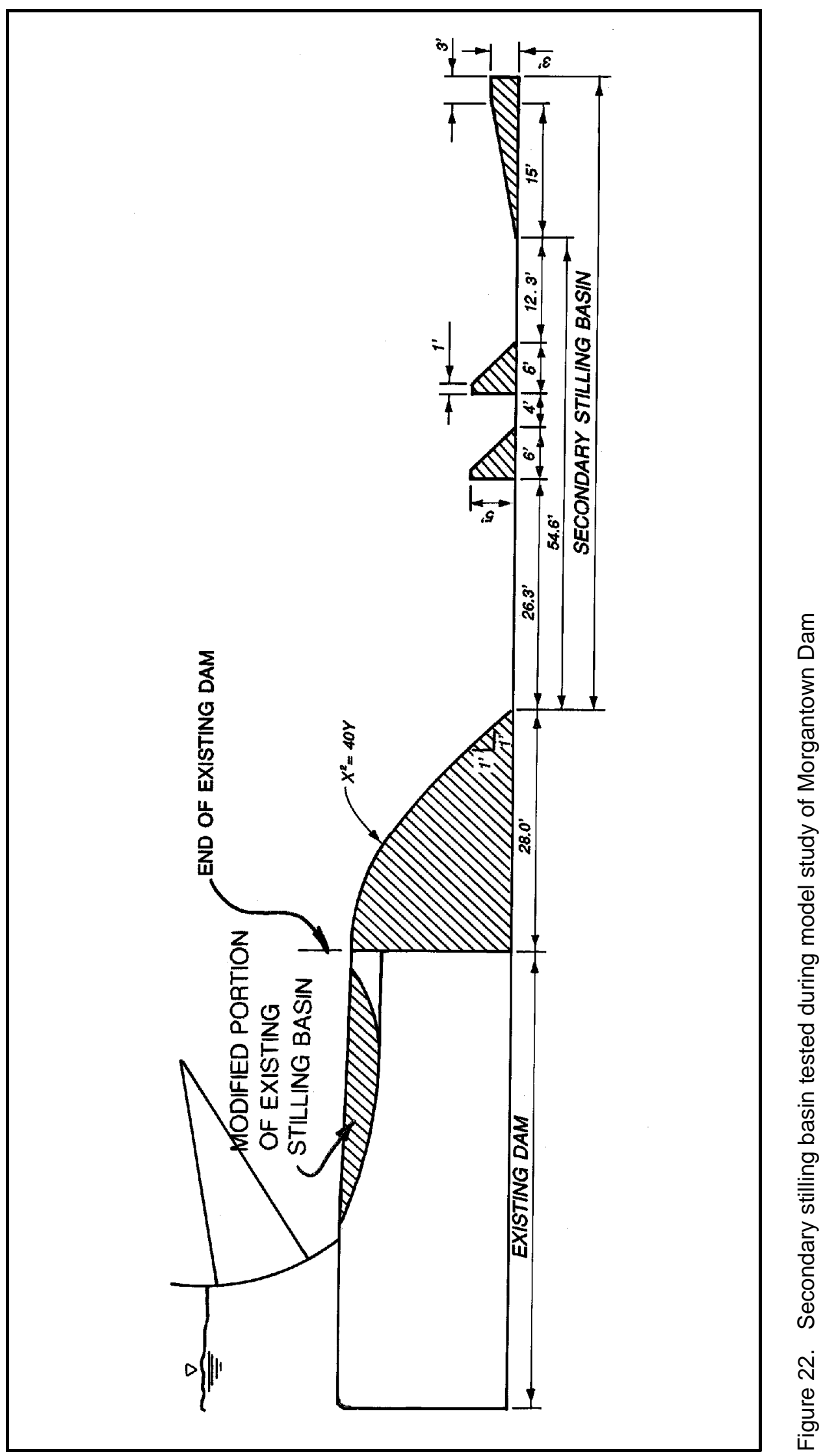




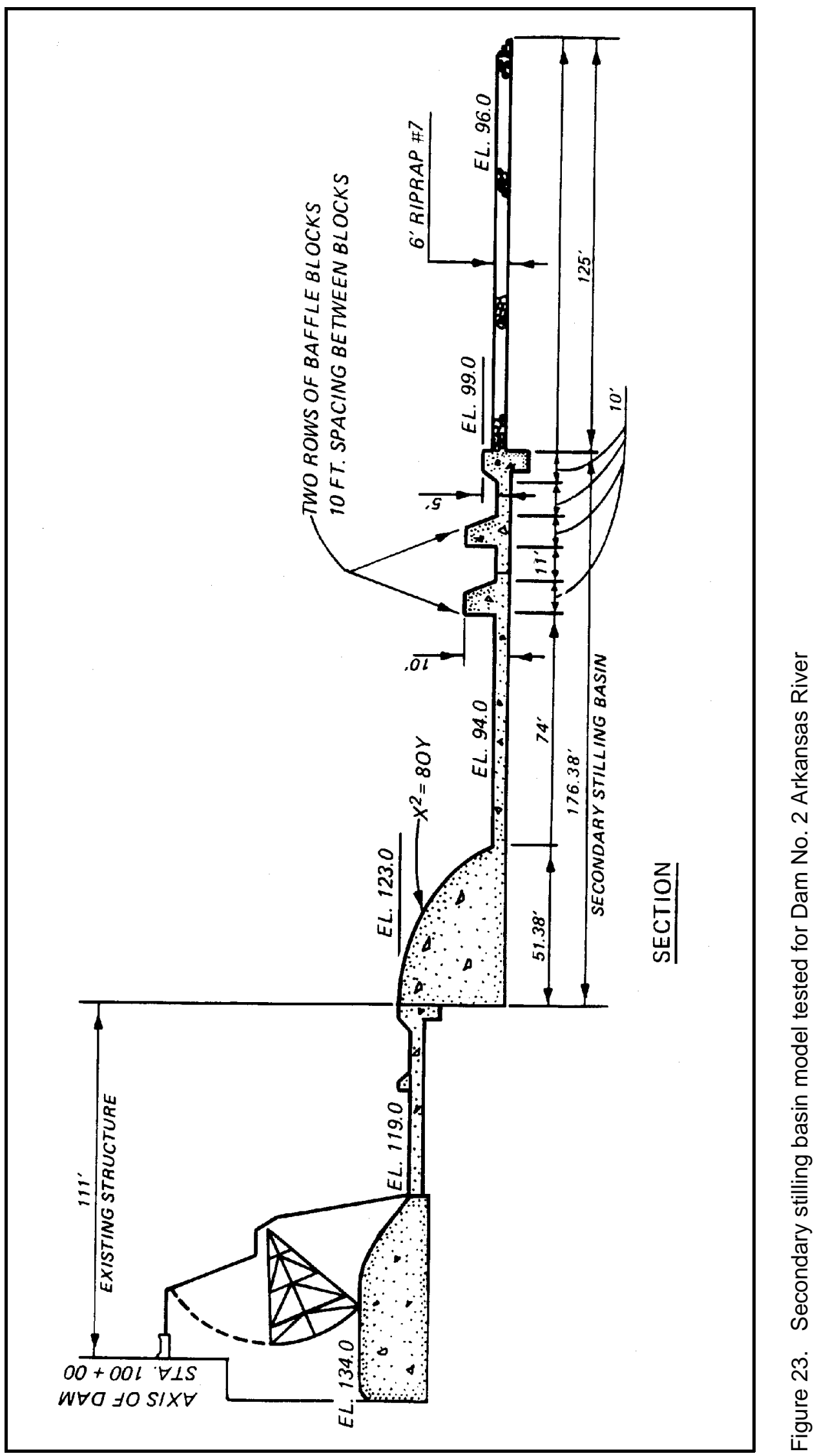




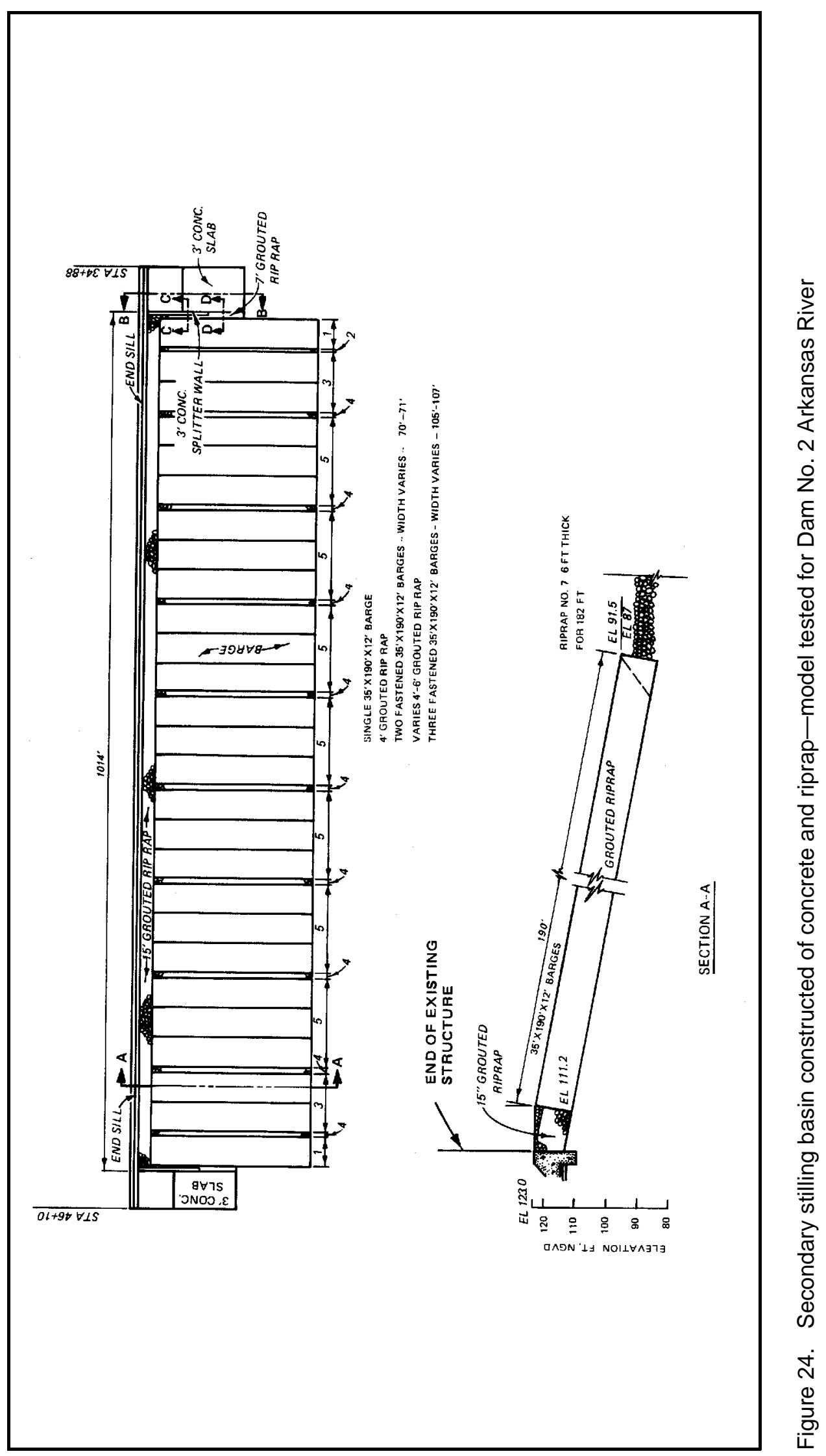




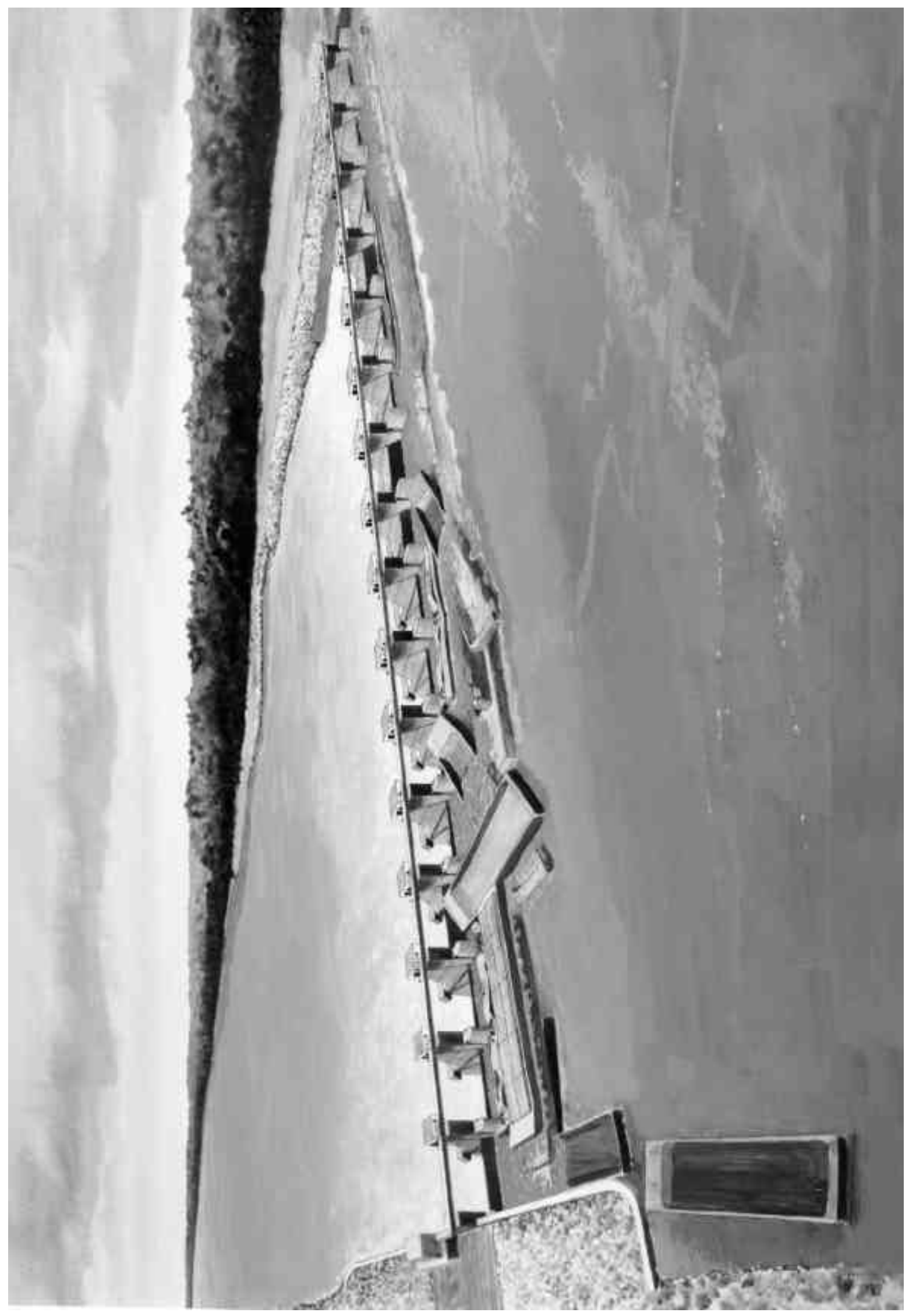

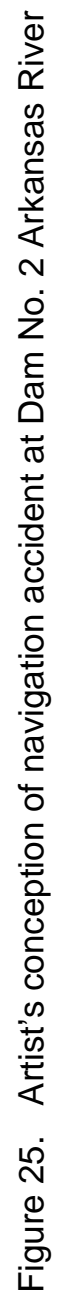




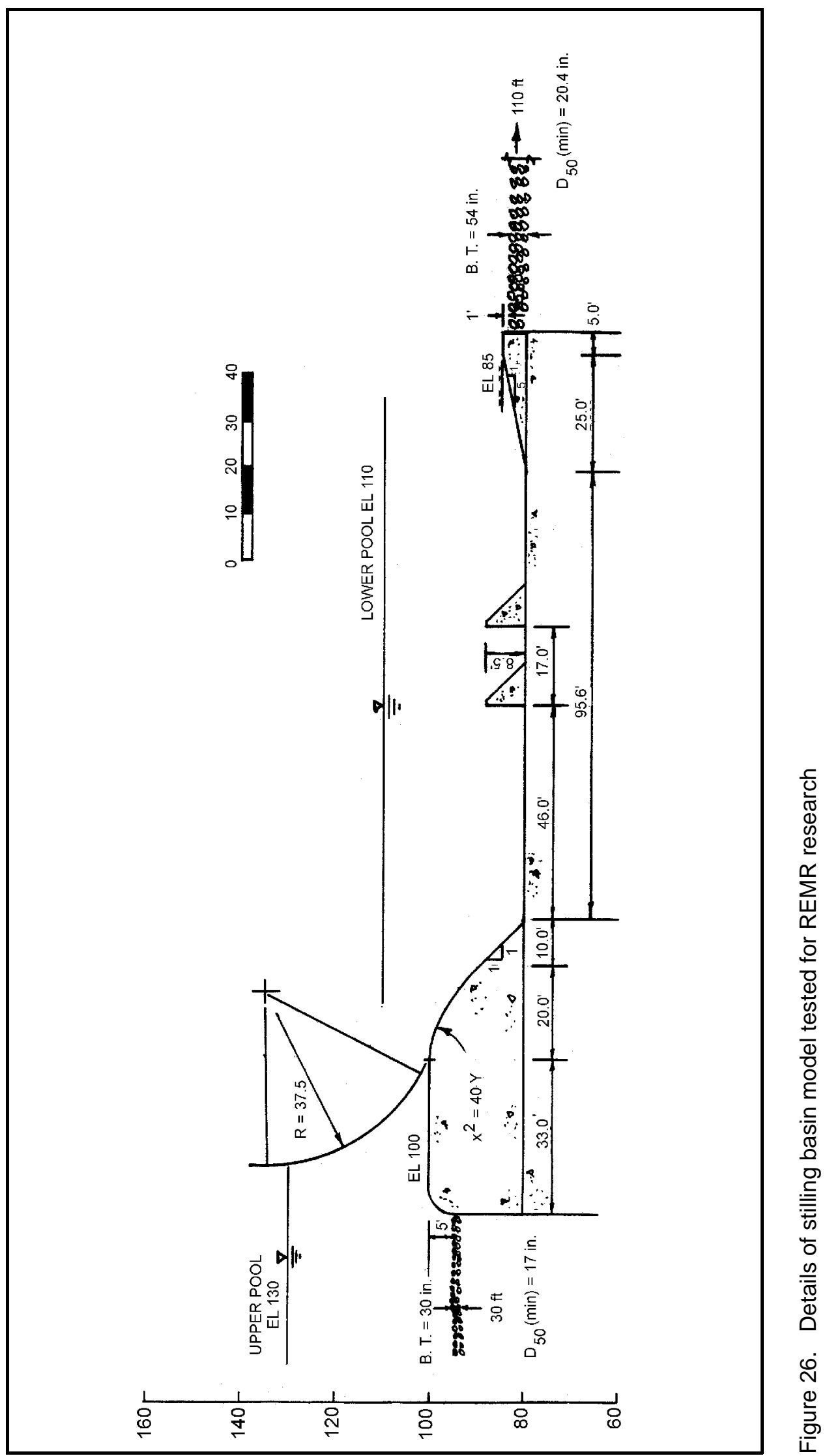




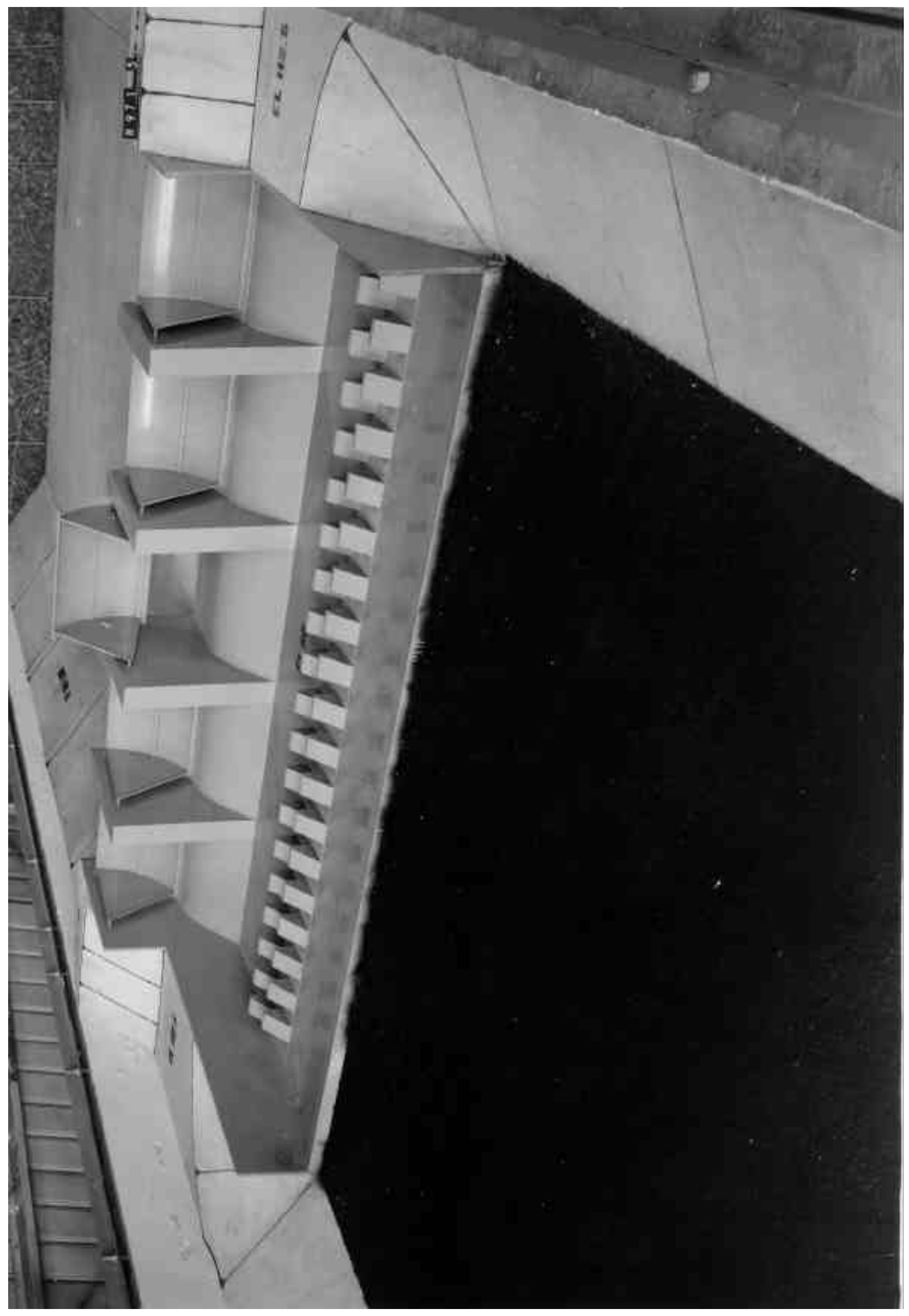

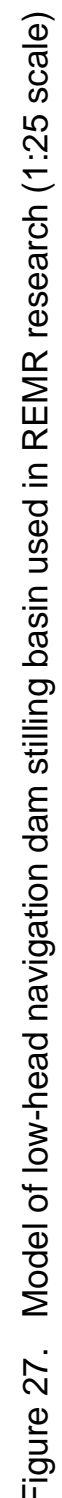


effectiveness of the stilling basin. Results affecting stilling basin design will be discussed in the following paragraphs.

Performance of this basin for the design conditions is shown in Figure 28 and was considered good. A hydraulic jump forced by the baffle blocks occurred in the basin, and average velocities over the end sill were distributed as shown in Figure 29. The highest velocities were measured in the top 40 percent of the flow depth and were indicative of those expected with a unit discharge entering the basin of $542 \mathrm{cfs} / \mathrm{ft}$ and a gate bay width of $60 \mathrm{ft}$. The velocities measured $1 \mathrm{ft}$ over the end sill were almost half those measured near the surface. The velocities in the lower half of the flow exiting the basin produce the forces that significantly affect the stability of the scour protection immediately downstream from this stilling basin. A vertical distribution of velocities measured along the center line of the scour hole that developed downstream from the scour protection after a designated period of operation is shown in Figure 30. These measurements indicate a similar velocity profile (highest velocities near the surface) throughout the entire model exit channel. The magnitude of the surface velocities starts to decrease about $150 \mathrm{ft}$ downstream from the stilling basin, and bottom velocities are affected noticeably by the scour hole characteristics. Plan views of bottom and surface velocities in the exit channel are shown in Figures 31 and 32, respectively. Asymmetric distribution of the flow in the exit channel shown in Figures 31 and 32 is characteristic of single-gate operations. The flow discharged from the single gate with adjacent gates closed will typically not distribute uniformly after exiting the downstream scour protection. The flow direction is influenced strongly by the exit-channel configuration during and after the development of the scour hole. Flow circulations and return currents (flow in an upstream direction) are also characteristic of single-gate operations.

The stilling basin in Figure 26 was found to perform satisfactorily with a minimum tailwater equal to 80 percent of the theoretical depth required for the formation of a hydraulic jump $d_{2}$ for the design conditions. Satisfactory performance was claimed since the downstream scour protection did not fail. The basin performance as indicated by the stability of the downstream scour protection was better for lower unit discharges. This should be expected since the basin would be overdesigned for these cases. Results with the lower unit discharges indicated that even though basin action consisted of a spray-type flow condition (loss of the forced jump action), the downstream scour protection remained stable. This is due primarily to the baffle blocks forcing the high- velocity flow to the surface; when the flow plunges back into the tailwater, most of it is still contained in the stilling basin.

Tests were also conducted with the baffle blocks removed from the stilling basin to observe the effect on the stability of the riprap. Average velocities measured over the end sill with a unit discharge of $400 \mathrm{cfs} / \mathrm{ft}$ and a tailwater to $d_{2}$ ratio of 1.15 are shown in Figure 33. The velocities $1 \mathrm{ft}$ over the end sill were twice as high as those near the surface illustrating the importance baffle blocks have on the stability of the downstream scour protection. 


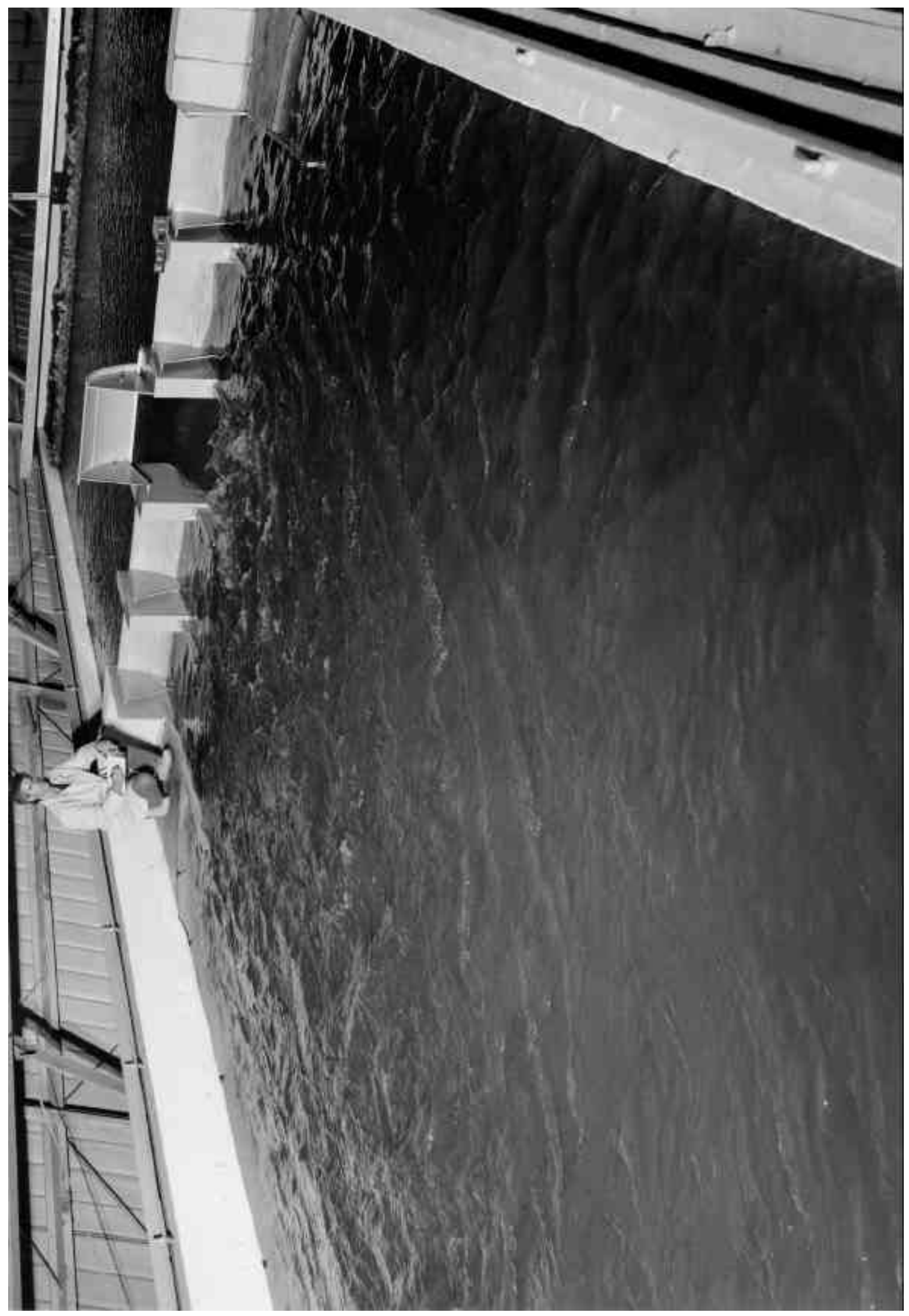

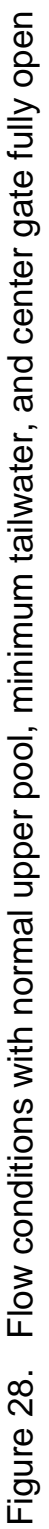




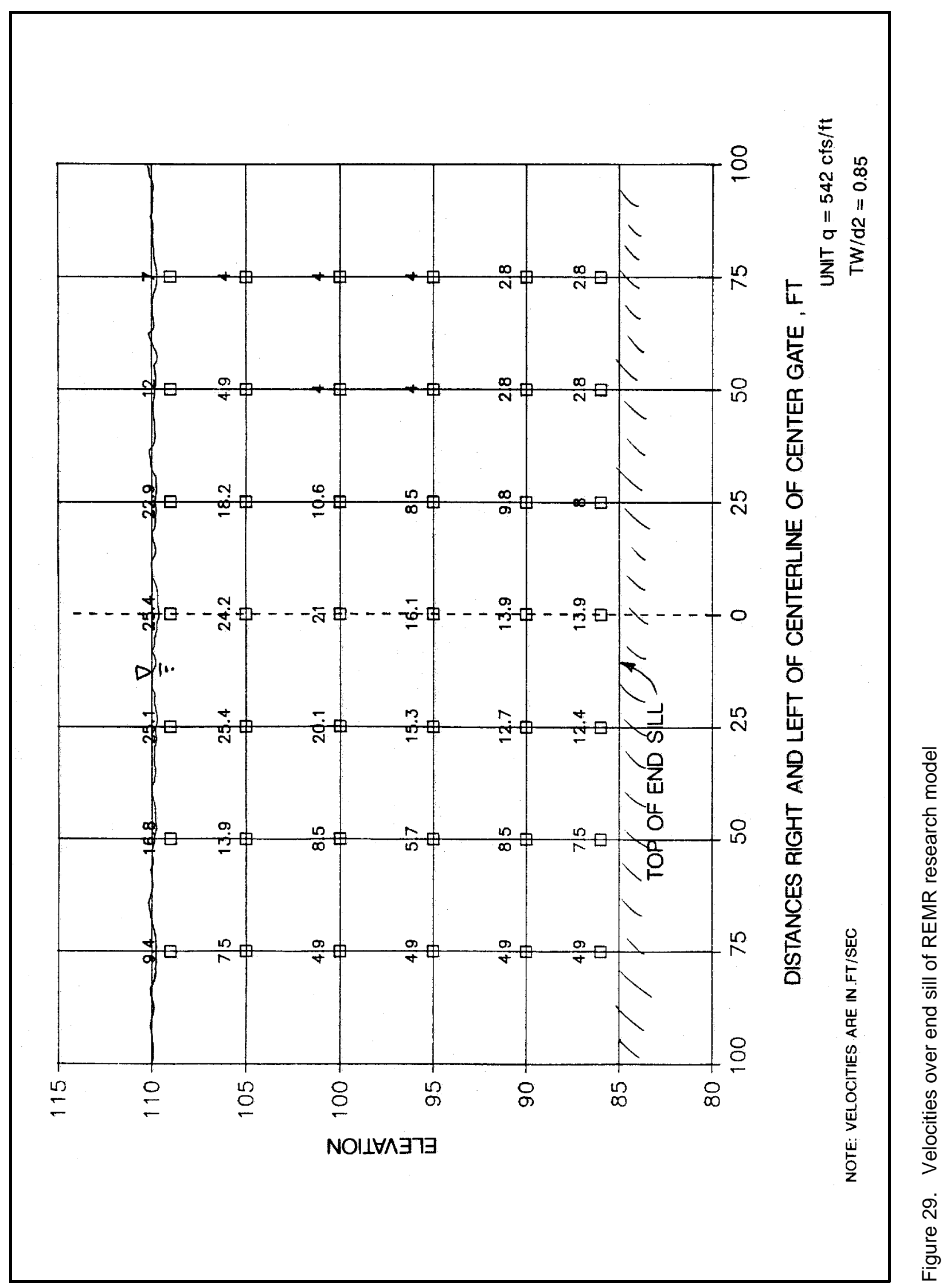




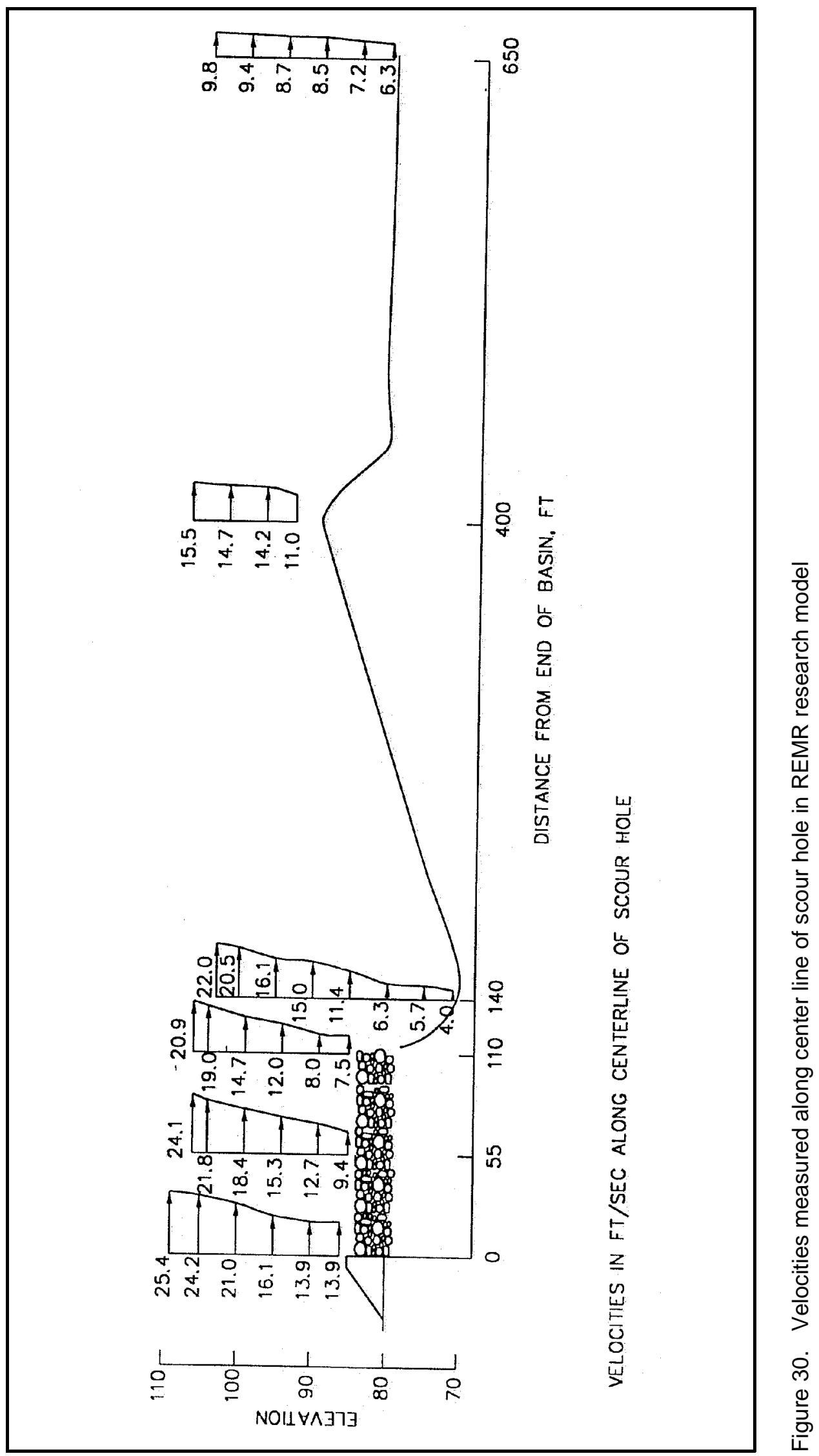




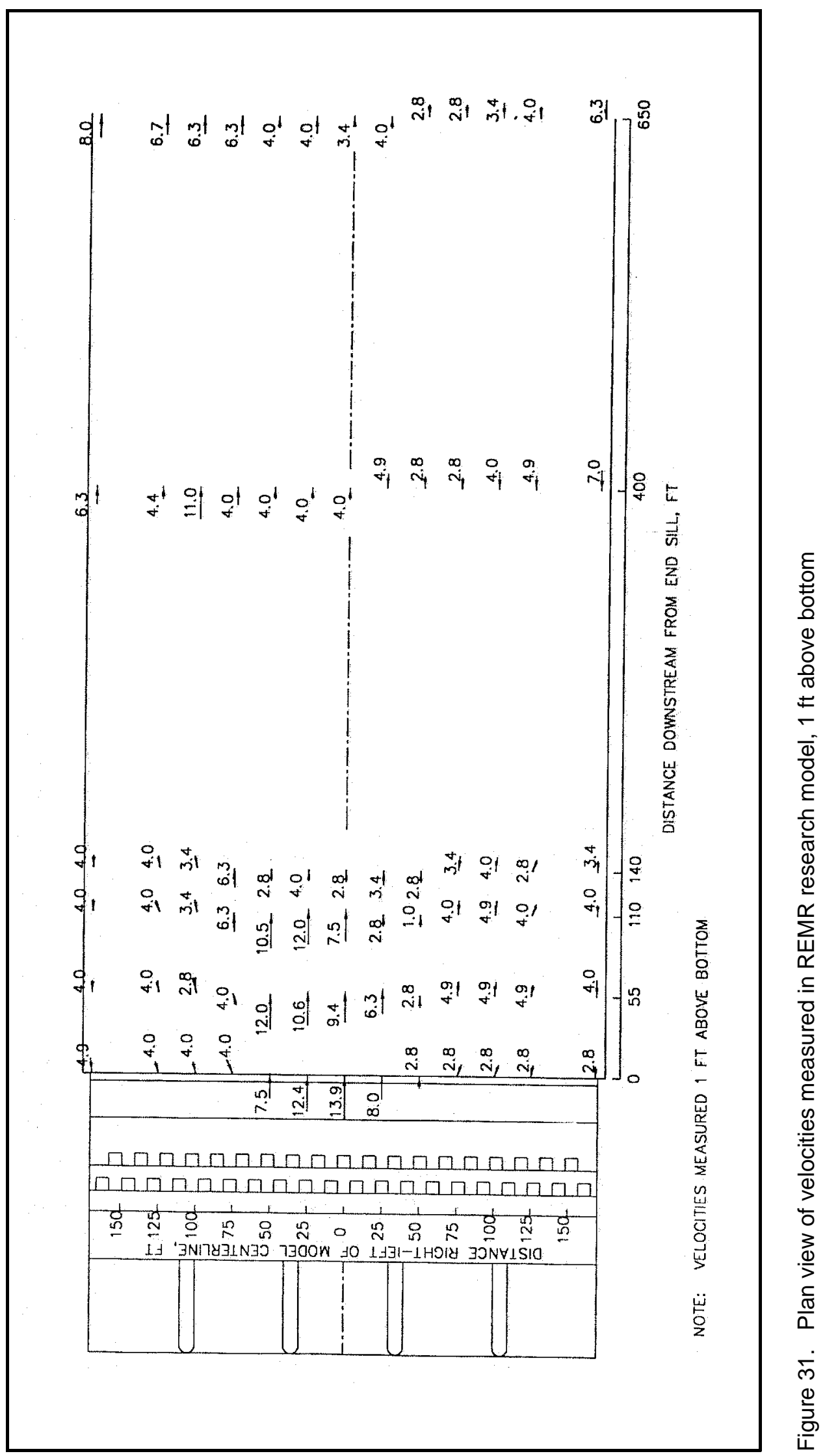




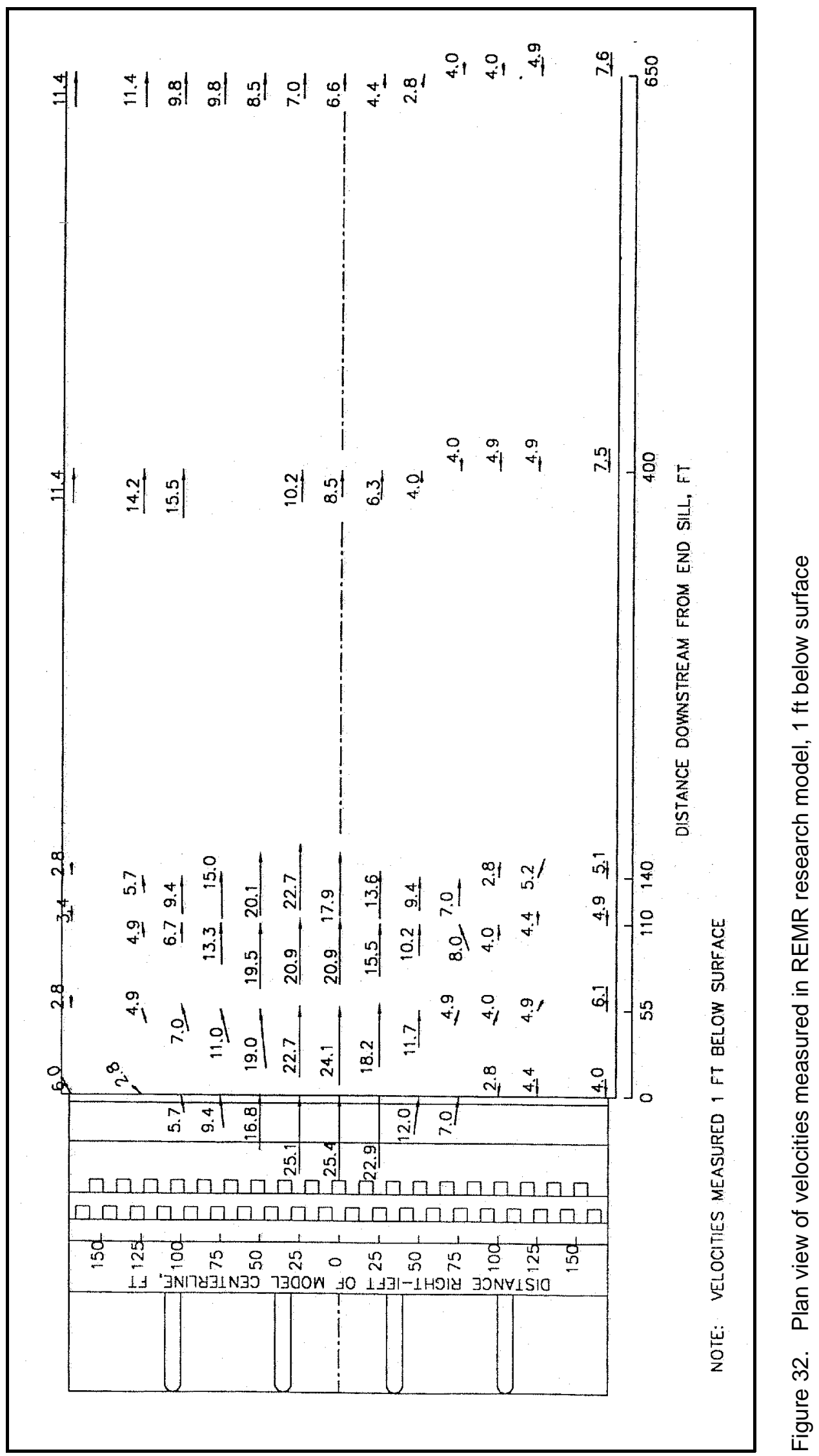




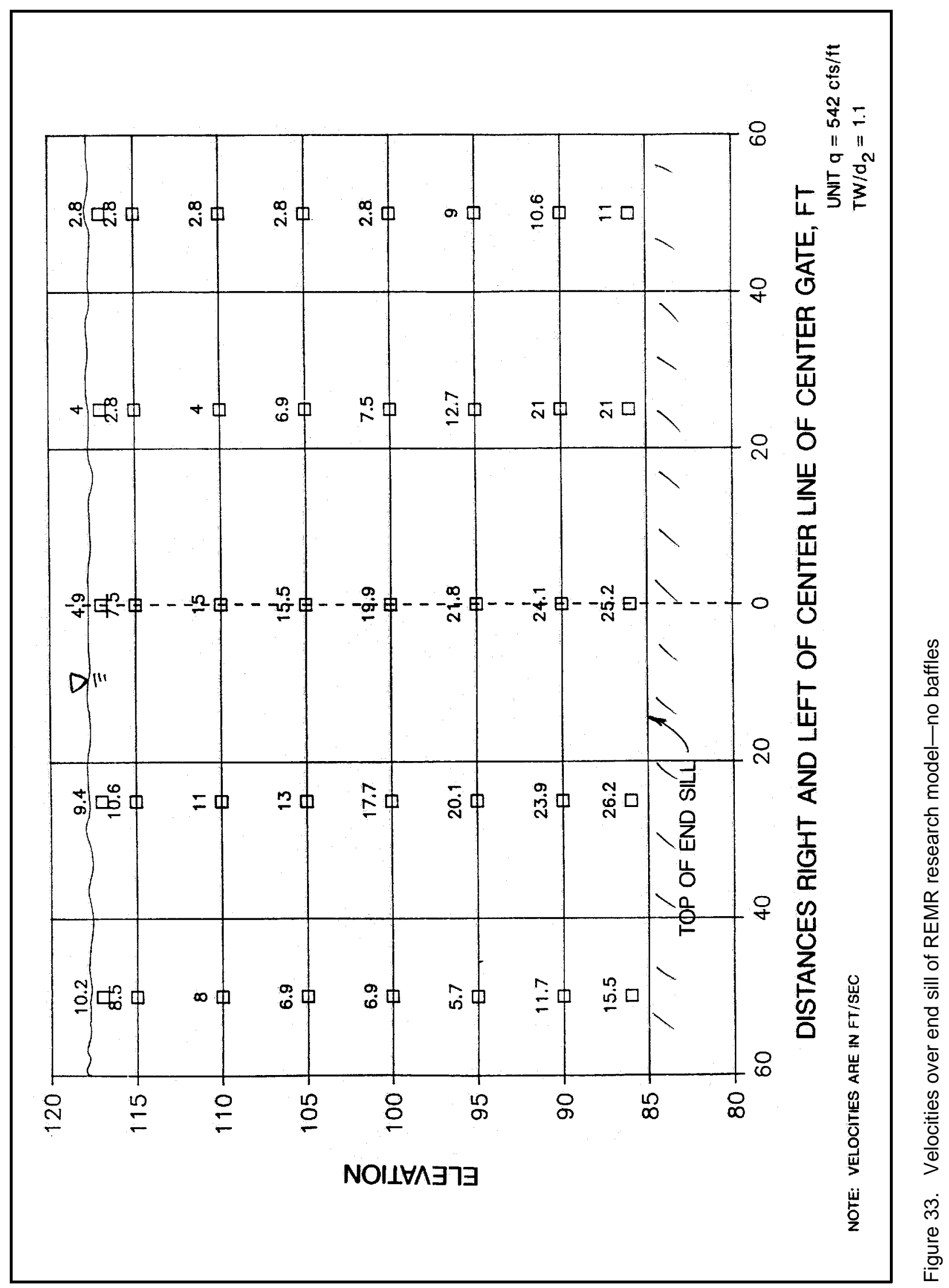


Another element of stilling basin design, gate pier extensions, was briefly addressed in the research model. Design flow conditions with and without gate pier extensions are shown in Figures 34 and 35. Energy dissipation in the stilling basin was better with the gate piers extended to $5 \mathrm{ft}$ upstream from the first row of baffles for single-gate operations. The stilling basin was more effective since side flows from the adjacent closed gates were not permitted to influence basin action downstream from the open gate. Surface flow patterns in Figure 35 show how the flow is concentrated when gate pier extensions are not utilized. Additional tests to optimize the length of the gate pier extensions could not be conducted because of additional riprap stability tests that had to be performed.

The literature review revealed how the current method for stilling basin design in EM 1110-2-1605 (USACE 1987) has evolved. Low-head navigation dam stilling basins were initially designed for adequate performance with normal water levels and equal gate operations. Operation of these projects showed that many times gates had to be operated in emergency conditions resulting in unsatisfactory basin performance. The downstream channel usually suffered from many of these operations, and repair was often required. These repairs sometimes cost as much as the original project. Stilling basin design procedures began to change in the early 1960s to accommodate some of the emergency operating conditions that had been observed. The stilling basin design became influenced by the flow conditions resulting from single-gate operations with normal upper pool and minimum project tailwater and were considered representative of emergency conditions. Model studies of Lock and Dam 26 on the Mississippi River, Aliceville and Columbus dams on the Tenn-Tom Waterway, and the Red River Dams where stilling basins were designed specifically for emergency operating conditions indicated the need for longer basin lengths, deeper apron elevations, baffle blocks, gate pier extensions, and sloping end sills. This literature review was conducted for gated navigation dams since the wide range of flow conditions a project must now operate under usually necessitates a gated section. Hite (1988b) and Rothwell, Oswalt, and Maynord (1981) provide information concerning stilling basins for uncontrolled fixed-crest dams. 


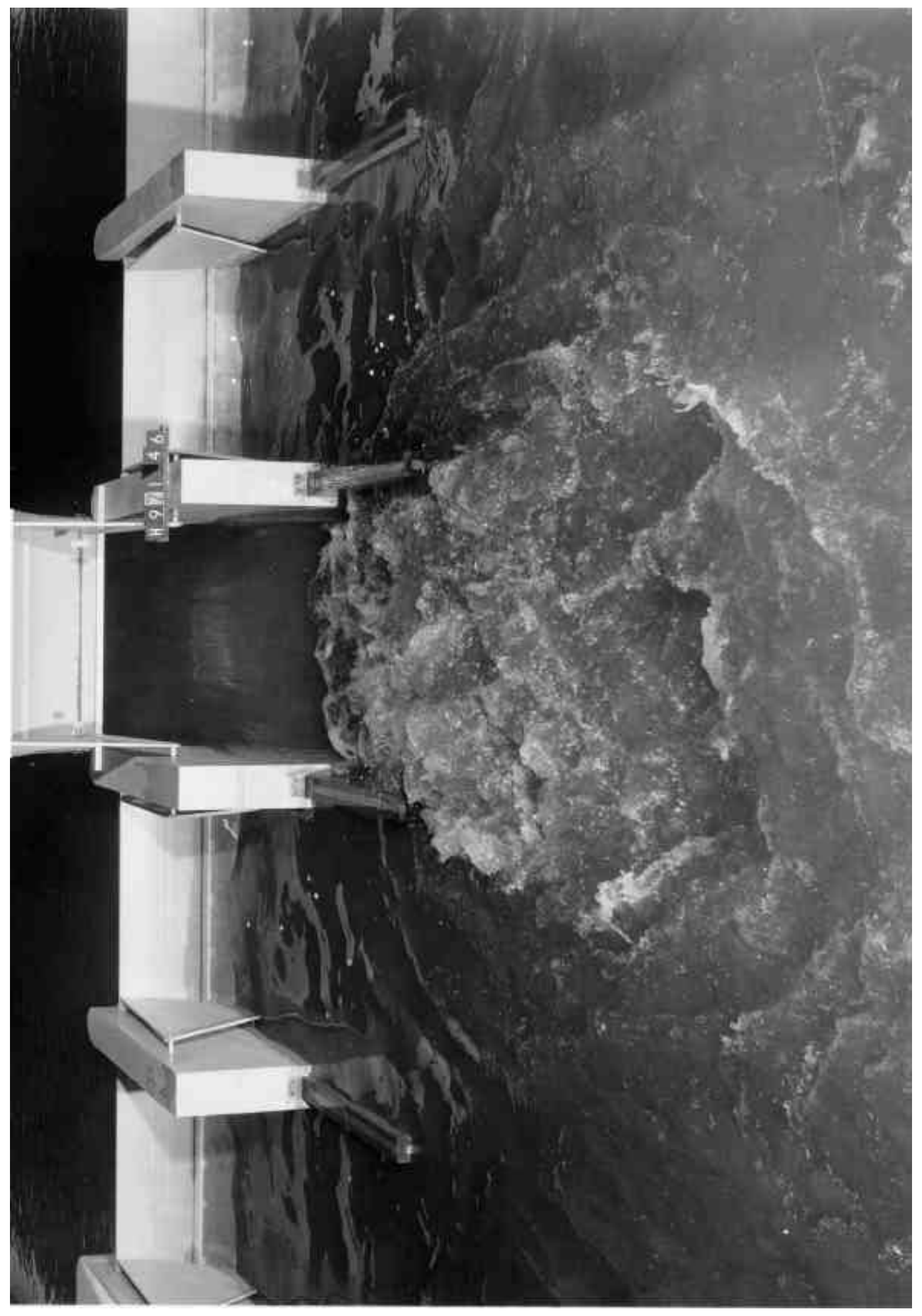

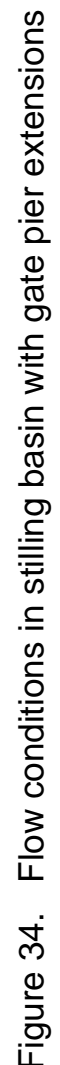




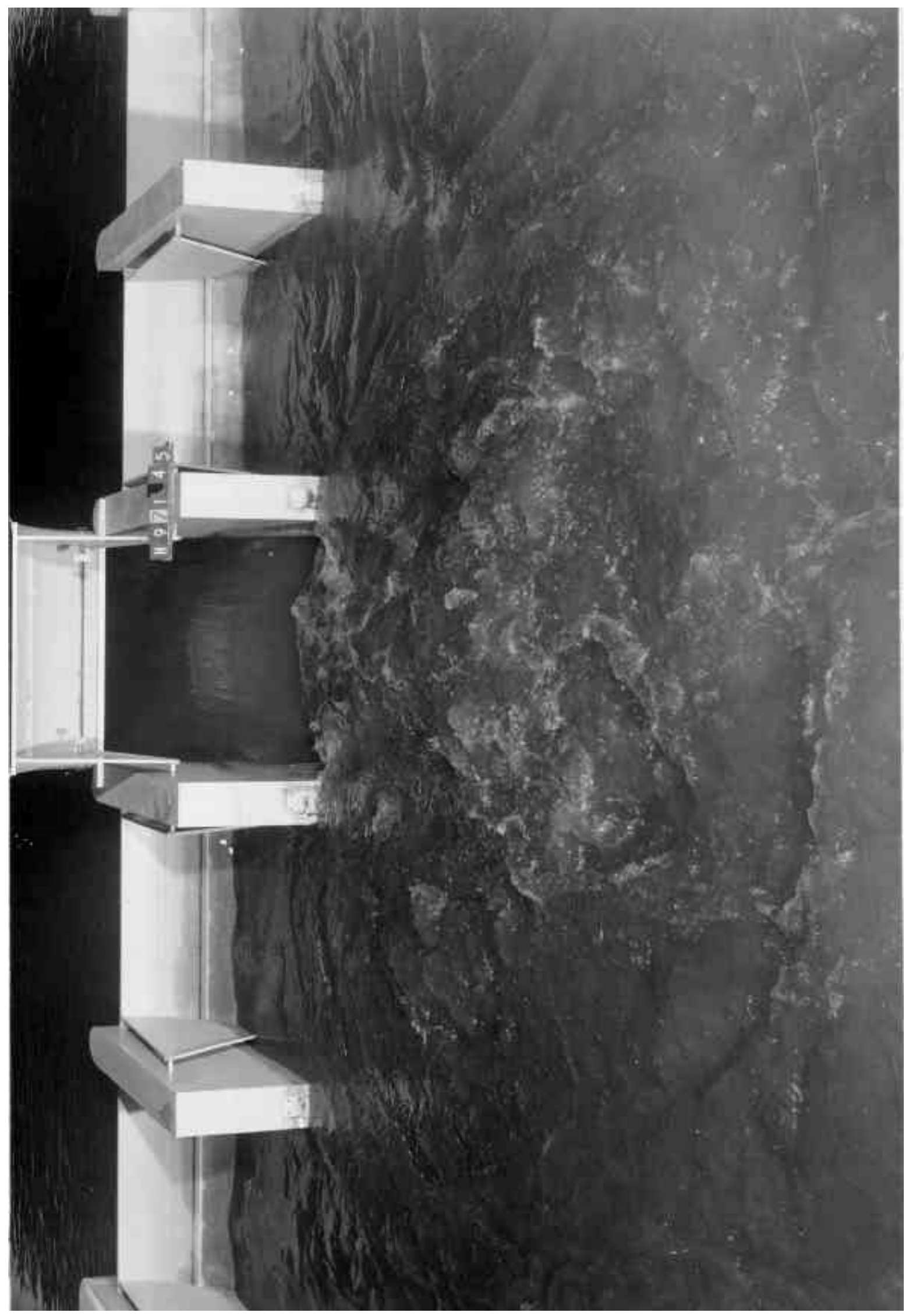

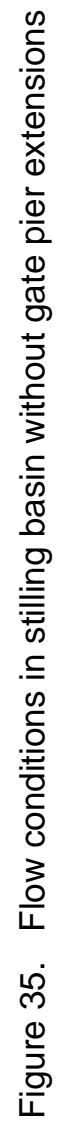




\section{Hydraulics of Low-Head Navigation Dam Stilling Basins}

The flow conditions in a stilling basin can usually be described as one of the following:

a. Supercritical flow. The jet entering the basin either sweeps through the stilling basin or impinges upon baffles or sills and sprays into the exit area. This is often referred to as a spray condition.

b. Forced jump. The tailwater is less than required for formation of hydraulic jump, and action is dependent primarily upon baffles or sills.

c. Hydraulic jump. The entering jet is broken up by turbulence and spreads throughout the entire depth of tailwater. Energy dissipation is excellent. Baffles and sills assist in energy dissipation.

d. Submerged jump. Tailwater is in excess of the optimum for a hydraulic jump, and the nappe at the gate lip is submerged for gated flows. The jet spreads from the apron throughout the entire depth of tailwater, and the baffles and sills can still be effective.

e. Surface jet. The entering jet rides the surface of the tailwater, and bottom velocities usually are in upstream direction and of very low magnitude. High-velocity surface flow can occur that continues downstream and could result in serious bank erosion and/or undesirable navigation conditions.

f. Undulating jet (free nappe). The jet is forced to the surface immediately below the gate and then dives through the tailwater to the bottom. An excessively long stilling basin would be required to prevent serious attack on channel bottom. 
g. Undulating jet (submerged nappe). Generally the same as undulating jet with free nappe except tailwater submerges nappe immediately below gate. Characterized by considerable surface wave action.

An optimum stilling basin design would be one that maintains a good hydraulic jump for the entire range of upper pools, tailwater elevations, and gate openings. Unfortunately, this cannot be accomplished at most projects because of the wide range of conditions. Therefore, a design is needed that functions satisfactorily for all flow conditions and prevents damage to the structure for the worst conditions. For a low-head navigation dam stilling basin, these worst conditions are usually a spray or forced jump and are caused by emergency operating conditions.

Therefore, the basin is designed for these conditions.

Basic hydraulic information used in the design of a stilling basin is obtained from a simplified version at the energy equation. This information is shown schematically in Figure 1. Assuming no energy loss, the energy equation is written as Equation 1 between the upper pool and the section where flow enters the stilling basin.

$$
\left(\text { U.P.E. }+\frac{V_{0}^{2}}{2 g}\right)=\text { A.E. }+\frac{V_{1}^{2}}{2 g}+d_{1}
$$

where

$$
\begin{aligned}
\text { U.P.E. } & =\text { upper pool elevation } \\
V_{0} & =\text { velocity in upper pool } \\
g & =\text { acceleration because of gravity } \\
A . E . & =\text { stilling basin apron elevation } \\
V_{1} & =\text { velocity of flow entering stilling basin } \\
d_{1} & =\text { depth of flow entering stilling basin }
\end{aligned}
$$

A trial-and-error technique can be used to solve for $V_{l}$ and $d_{l}$ knowing the upper pool elevation, the velocity head upstream (if significant), and the discharge. Knowing $V_{l}$ and $d_{1}$, the Froude number of flow entering the stilling basin is computed from

$$
F_{1}=\frac{V_{1}}{\sqrt{g d_{1}}}
$$

The momentum equation is then used to determine the ratio between depths before and after the hydraulic jump according to 


$$
\frac{d_{2}}{d_{1}}=\frac{1}{2}\left(\sqrt{1+8 F_{1}^{2}}-1\right)
$$

where $d_{2}$ is depth after the hydraulic jump.

This form of the momentum equation ignores the forces on the baffle blocks in the analysis. Information on these forces can be found in EM 1110-2-1603 (USACE 1965) and Basco (1970). The assumed stilling basin elevation is then checked against the available tailwater according to

$$
\text { Tailwater - Assumed Basin Floor El }=c d_{2}
$$

where $c$ is a coefficient depending on stilling basin design and has been observed to vary from 0.7 to 1.0 , and the tailwater is the tailwater for the design flow. A new stilling basin floor elevation is assumed until Equation 4 is satisfied. Use of a $c$ less than 1.0 in Equation 4 should only be used in conjunction with Equation 3, the simplified momentum approach.

The stilling basin designed for the conditions of single-gate operations with normal upper pool and minimum tailwater is not considered a hydraulic jumptype energy dissipater. Murphy (1980) stated that primary dissipation results from impact of the jet against the baffles and lateral spreading of the jet, with tailwater as a supporting element. 


\section{Available Design Procedures}

Considerable design information is available in EM 1110-2-1605 (USACE 1987), Hydraulic Design Criteria (WES 1988), and EM 1110-2-1603 (USACE 1965). The following paragraphs will discuss information presented in these references along with guidance obtained from analyzing results of recent model tests and the review of the literature. The stilling basin guidance presented is intended for the stilling basin designed for single-gate operations with minimum tailwater.

\section{Basin Elevation}

The low-head navigation dam stilling basin is more of an impact-type energy dissipater rather than a baffle-assisted hydraulic jump type. The requirement that the basin be placed at an elevation that provides 85 percent of the depth required for the formation of a hydraulic jump $d_{2}$ was not evident in review of previous model information. Figure 36 presents a plot of $T W / d_{2}$ versus $F_{1}$ for the model stilling basins shown in Table 2 . These studies were chosen for analysis since their designs were tested for normal upper pool, single-gate operations, and minimum tailwater. No obvious relationship is evident. The ratio of $T W / d_{2}$ varied from 0.72 to 0.92 in these studies. Tests of the stilling basin utilized for the REMR research indicated the downstream scour protection remained stable for $T W / d_{2}$ ratios greater than and equal to 0.8 . That 0.85 be used for preliminary design is suggested, and model tests should be conducted to establish the final design.

\section{Basin Length}

Table 2 data indicate the value of the required length from toe of the trajectory to the beginning of the $1 \mathrm{~V}$-on-5H upslope $L z$ varied from 2.4 to 3.1. These data, shown as $L_{2} / d_{2}$ vs $F_{1}$ in Figure 37, suggest that most of the values fell between 2.5 and 3.0, and a value of 2.7 would be appropriate for initial design. The total length of paved area (from the toe of the trajectory to the start of the 


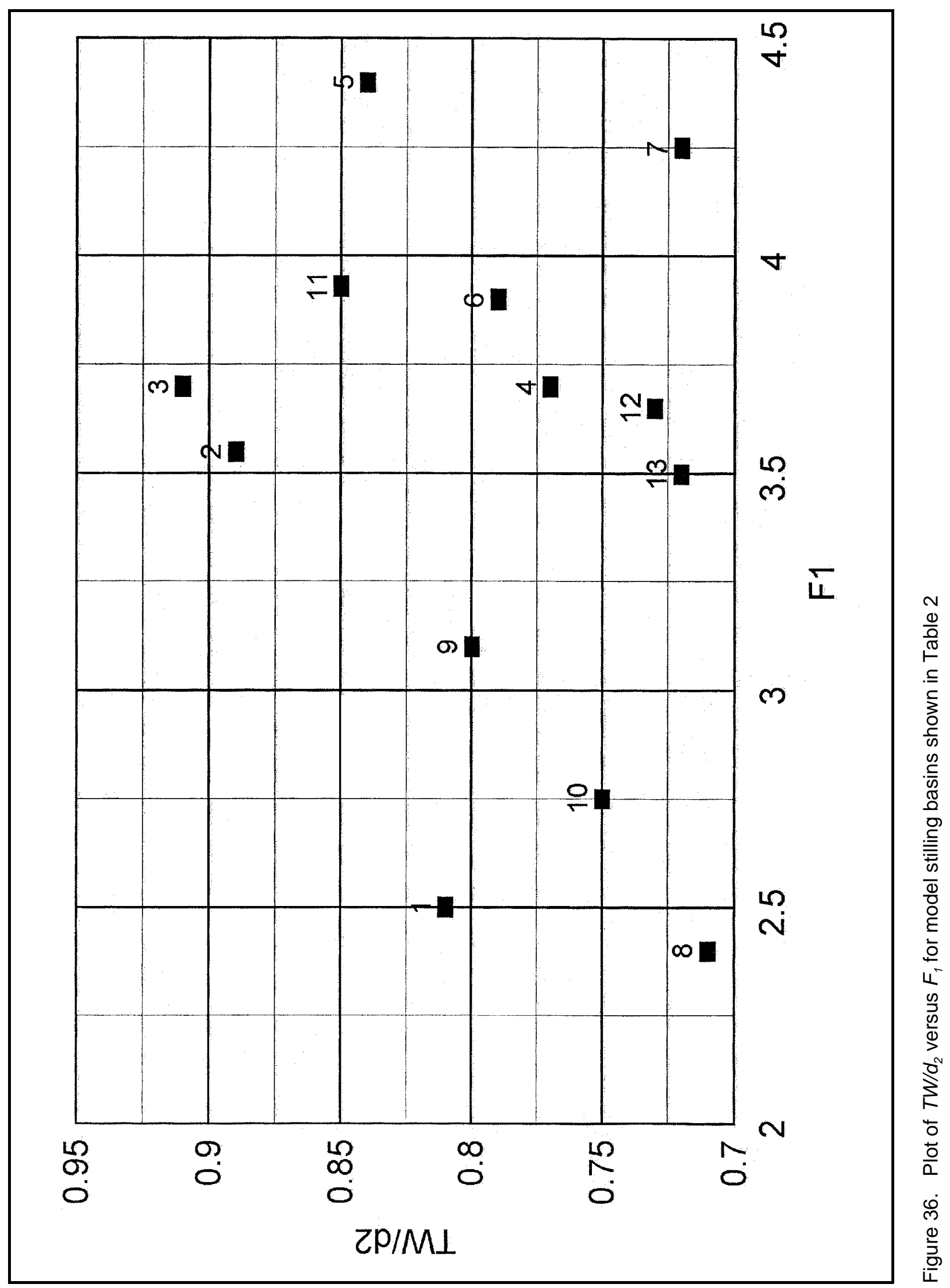




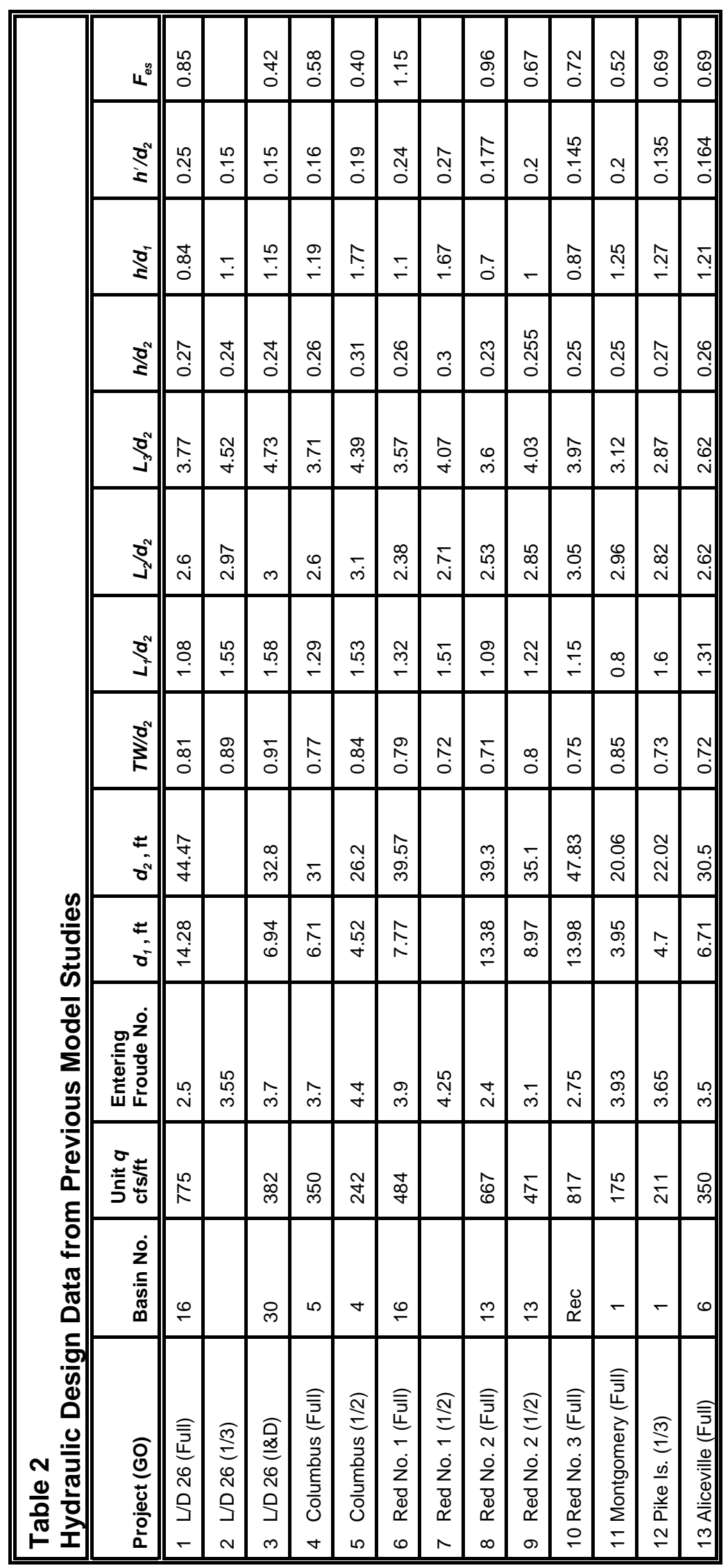




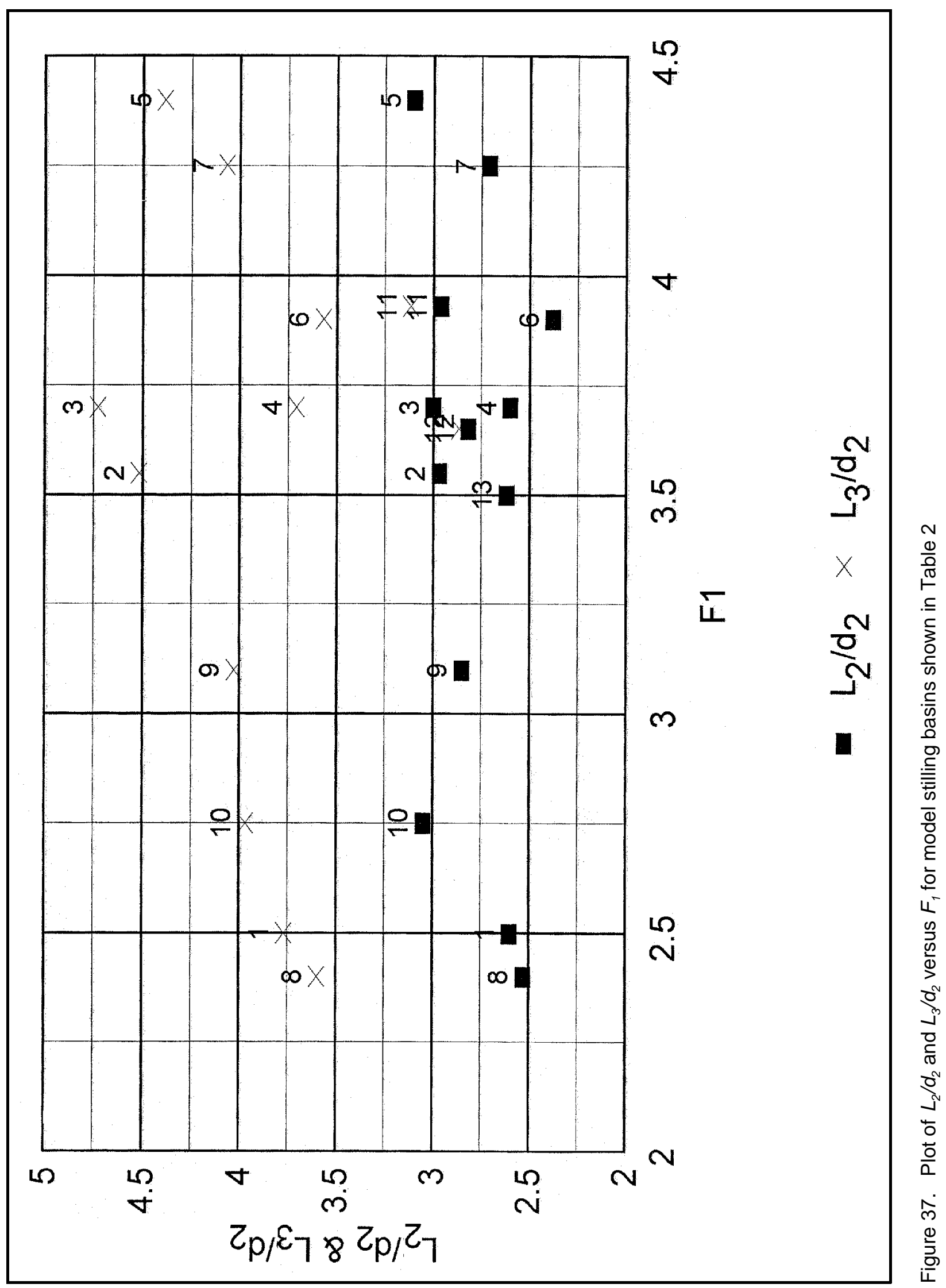


exit channel) varied from 2.6 to 4.6 and is shown as $L_{3} / d_{2}$ in Figure 37. This value is usually dependent on the configuration of the exit channel, and the data suggest a value of 4 for preliminary design.

\section{Baffles}

Since most of the energy dissipation is achieved through impact of the jet on the baffles, the size and location of the baffles are very important. Baffle height determined from data in Table 2 is shown in Figures 38 and 39, respectively. The baffle height $h$ expressed as the ratio $h / d_{2}$ in Figure 38 indicates the data varied from 0.23 to 0.31 . The baffle height expressed as the ratio $h / d_{l}$ in Figure 39 shows the data varied from 0.72 to 1.77 and suggests a stronger relationship than Figure 38. A best fit line was computed for the data in Figure 39, and the equation of the line is

$$
\frac{h}{d_{1}}=0.436 F_{1}-0.357
$$

This relationship could be used for $F_{1}$ between 2.5 and 4.5; however, the baffle block height should not exceed $0.3 d_{2}$, and if the height computed from the equation above is greater than $0.3 d_{2}$, then $0.3 d_{2}$ should used. The distance from the toe of the trajectory to the first row of baffles $L_{1}$ expressed as the ratio $L_{l} / d_{2}$ is plotted in Figure 40 versus the entering Froude number for the data in Table 2. The data suggest that the baffles be placed closer to the toe of the trajectory when the basin is designed for operations with a single gate fully open; for the higher $F_{1}$, more distance is needed. A second row of baffles is recommended; these baffles should be the same height as those in the first row, placed with their upstream face about two baffle heights downstream from the upstream faces of the first row and staggered with respect to the baffles in the first row. EM 1110- 2-1603 (USACE 1965 ) and Basco (1970) contain information for determining forces on the baffle blocks.

\section{Gate Pier Extensions}

Gate pier extensions are essential for single-gate operations because they prevent return flow from the adjacent closed gates. They should be extended to a position $5 \mathrm{ft}$ upstream from the baffles, and the top elevation should be $1 \mathrm{ft}$ higher than the tailwater used for single-gate half or fully opened criteria. The width of the piers can be less than the main spillway piers. Gate piers for some projects have been extended to the end of the stilling basin. This will tend to increase the unit discharge over the end sill that could cause the flow to spray off the baffles for a stilling basin designed with the apron elevation set at less than full $d_{2}$. Again, a model study is suggested for the final design. 


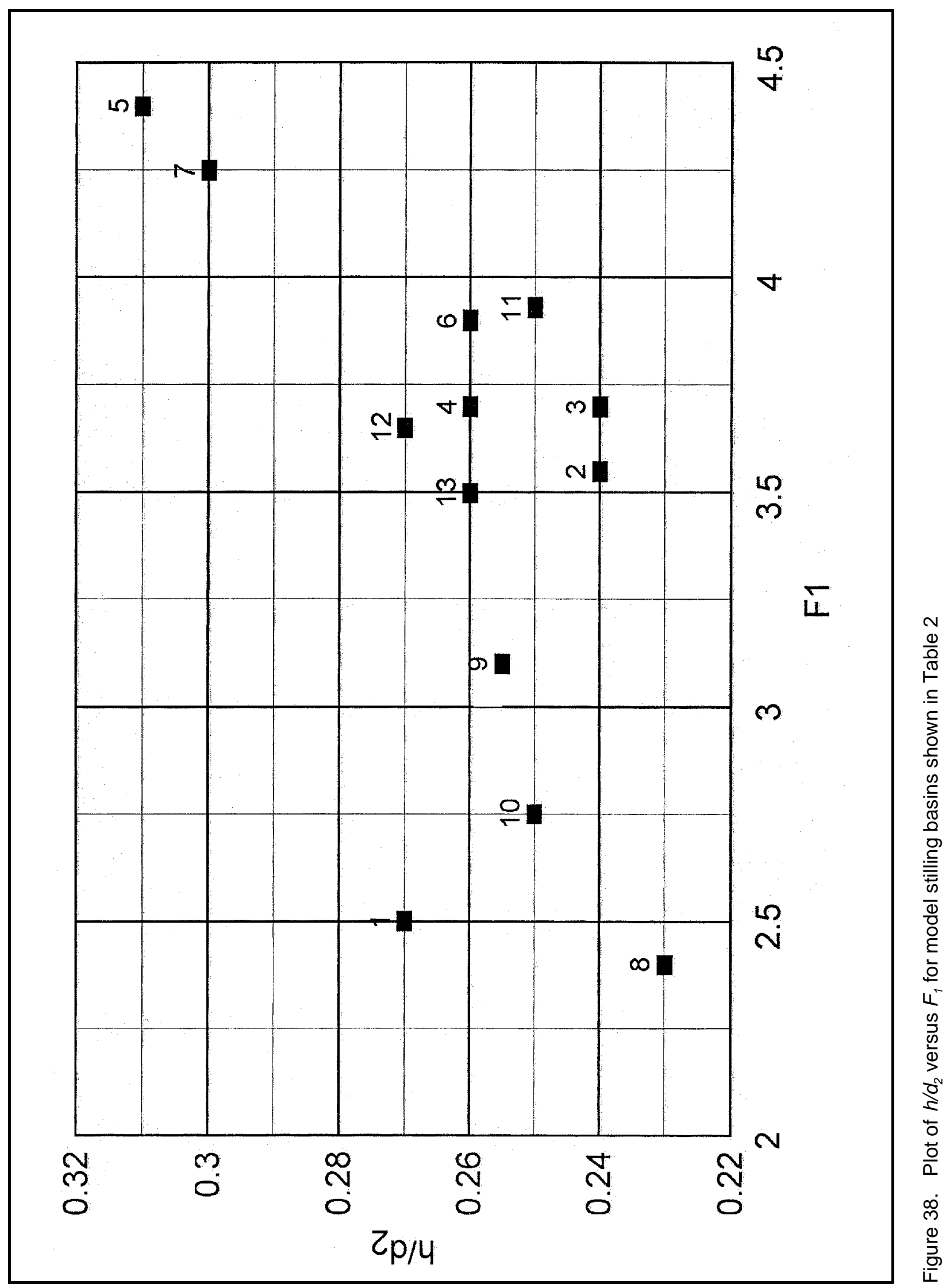




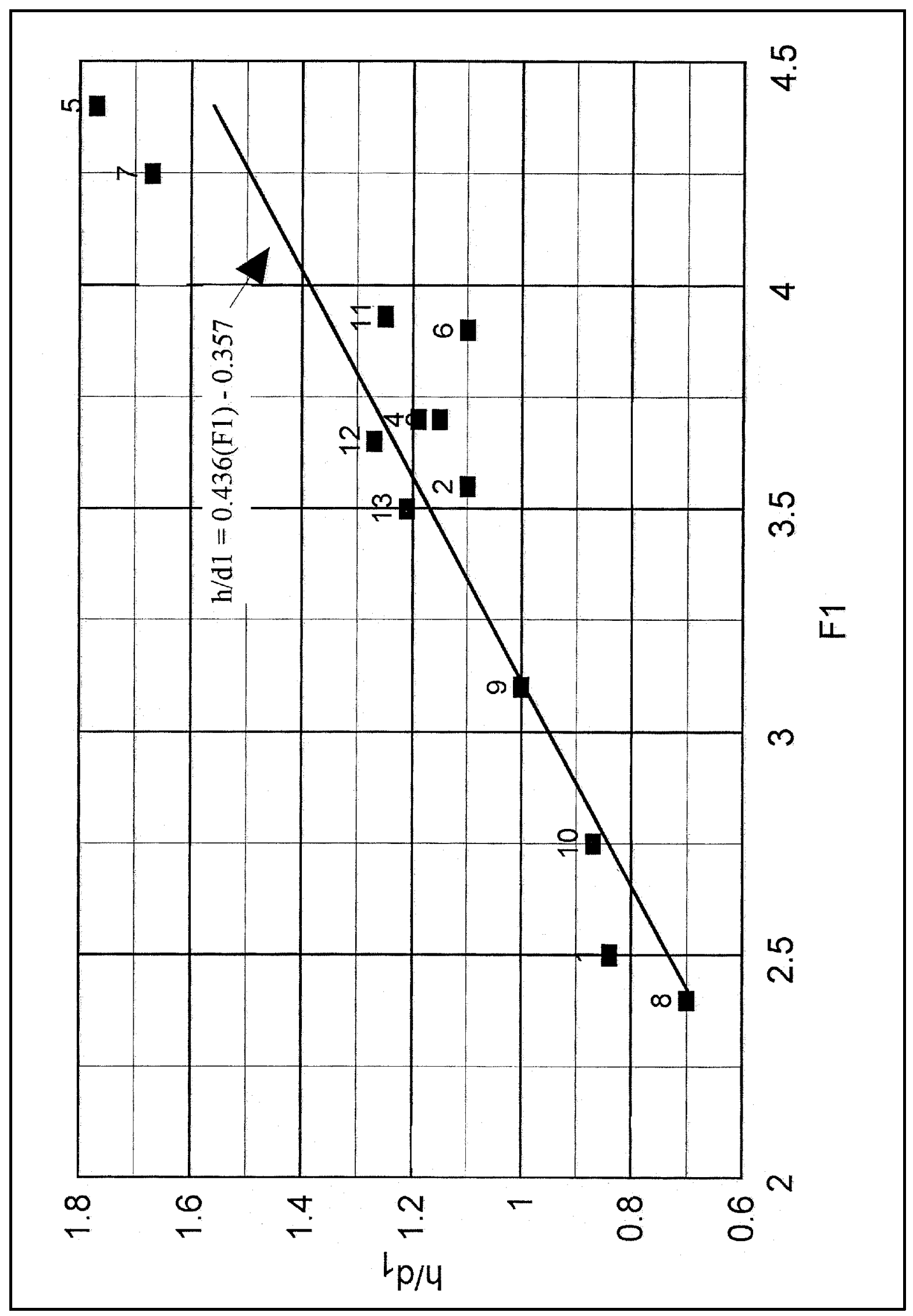

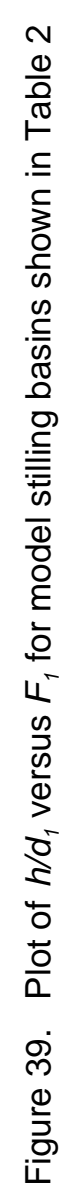




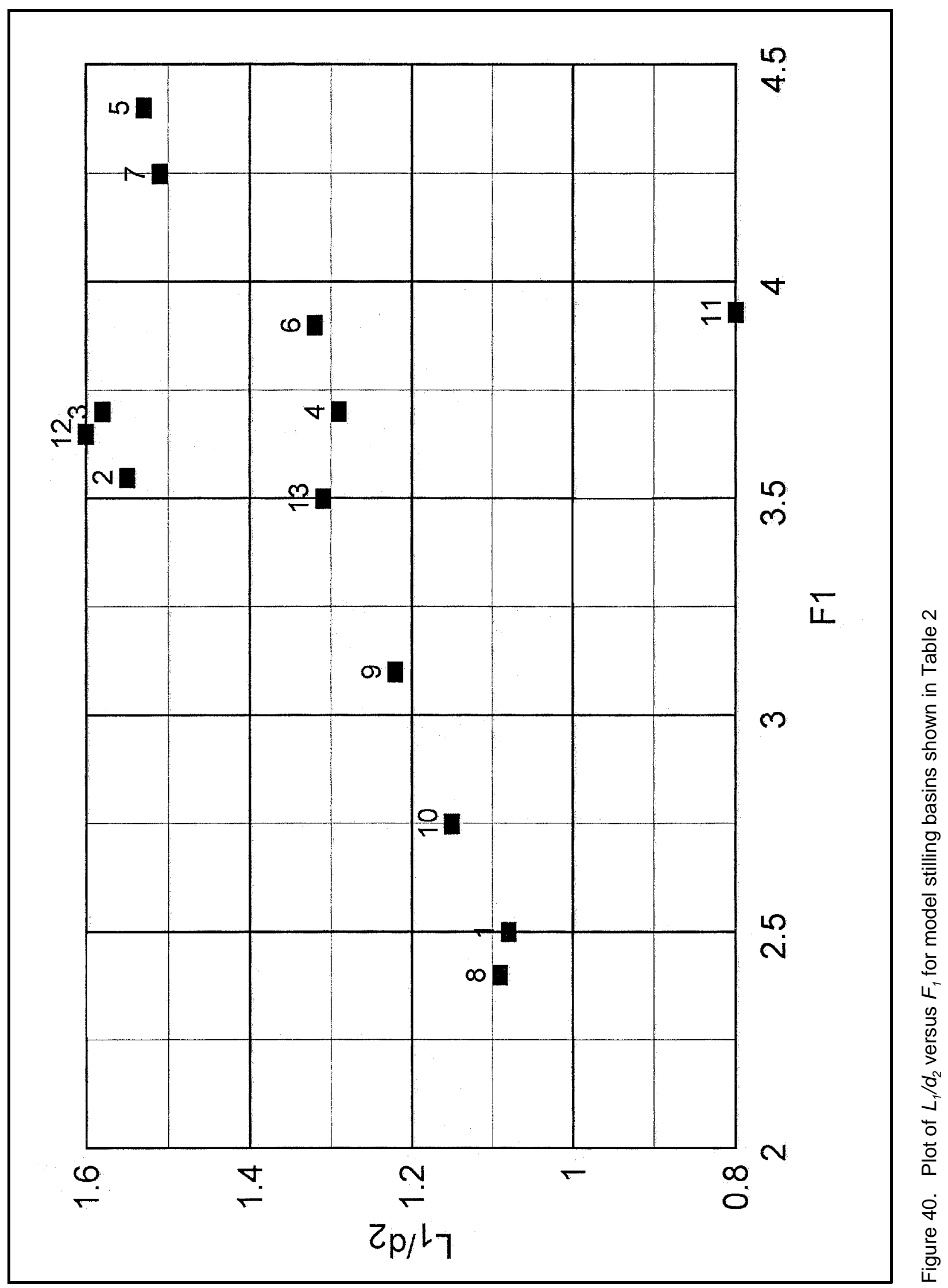




\section{End Sill}

Model tests indicate the end sill should slope up $1 \mathrm{~V}$ on $5 \mathrm{H}$ to effectively spread the jet during single-gate operations. The higher the end sill, the more effective it is; but there are limitations. A higher end sill results in shallower depths in the exit channel and could cause higher velocities over the riprap. The top of the end sill should not be appreciably higher than the exit channel, and it should not be so high that it causes the flow to drop through critical depth and form a secondary jump in the exit channel. The Froude number over the end sill defined as

$$
F_{\text {es }}=\frac{V_{\text {es }}}{\sqrt{g d}}
$$

where

$$
\begin{aligned}
d & =\text { depth of tailwater over end sill } \\
g & =\text { acceleration because of gravity } \\
V_{e s} & =0.78 \times q / d(q=\text { unit discharge through gate bay })
\end{aligned}
$$

should not exceed 0.86 to ensure critical flow does not occur. Experiments in a rectangular channel indicated tranquil flow became unstable when the Froude number was greater than 0.86 , thus the limiting value. The computed velocity over the end $q / d$ is reduced to account for the spreading of the flow that occurs with single-gate operations. The value of 0.78 is suggested and was determined from model tests of a stilling basin designed for $0.85 d_{2}$ with a single gate fully open. Excessive spreading is not desired because of attack on the boundaries of the outside bays. The Froude number over the end sill $F_{e s}$ was computed for comparable data in Table 2 and plotted against the height of the end sill $h^{\prime}$ expressed as a ratio of $h^{\prime} / d_{2}$. The resulting plot shown in Figure 41 shows no obvious pattern, and a plot of $h^{\prime} / d_{2}$ versus $F_{1}$ shown in Figure 42 also indicates there is no obvious pattern. The data suggest for $F_{1}$ between 2.5 and 4.5 the end sill height should be between 15 and 20 percent of $d_{2}$ for basins designed for either single gate fully or half opened.

\section{Training Walls}

Adjacent project features and topography have a major influence on the design of the training walls. They are normally extended at a constant top elevation (usually $2 \mathrm{ft}$ above the downstream normal pool elevation) to the end of the stilling basin; however, model tests have indicated that this is not a strict requirement. 


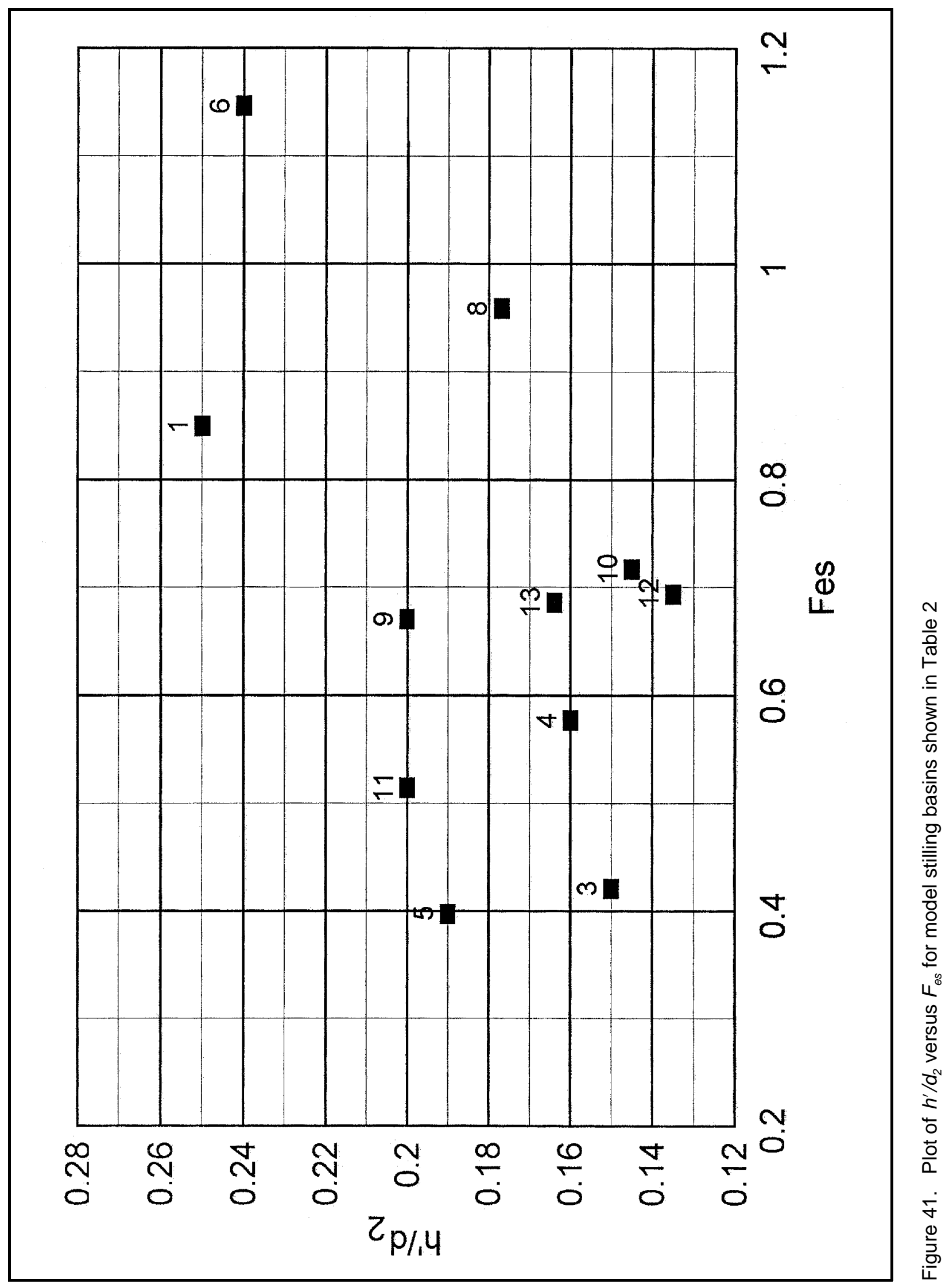




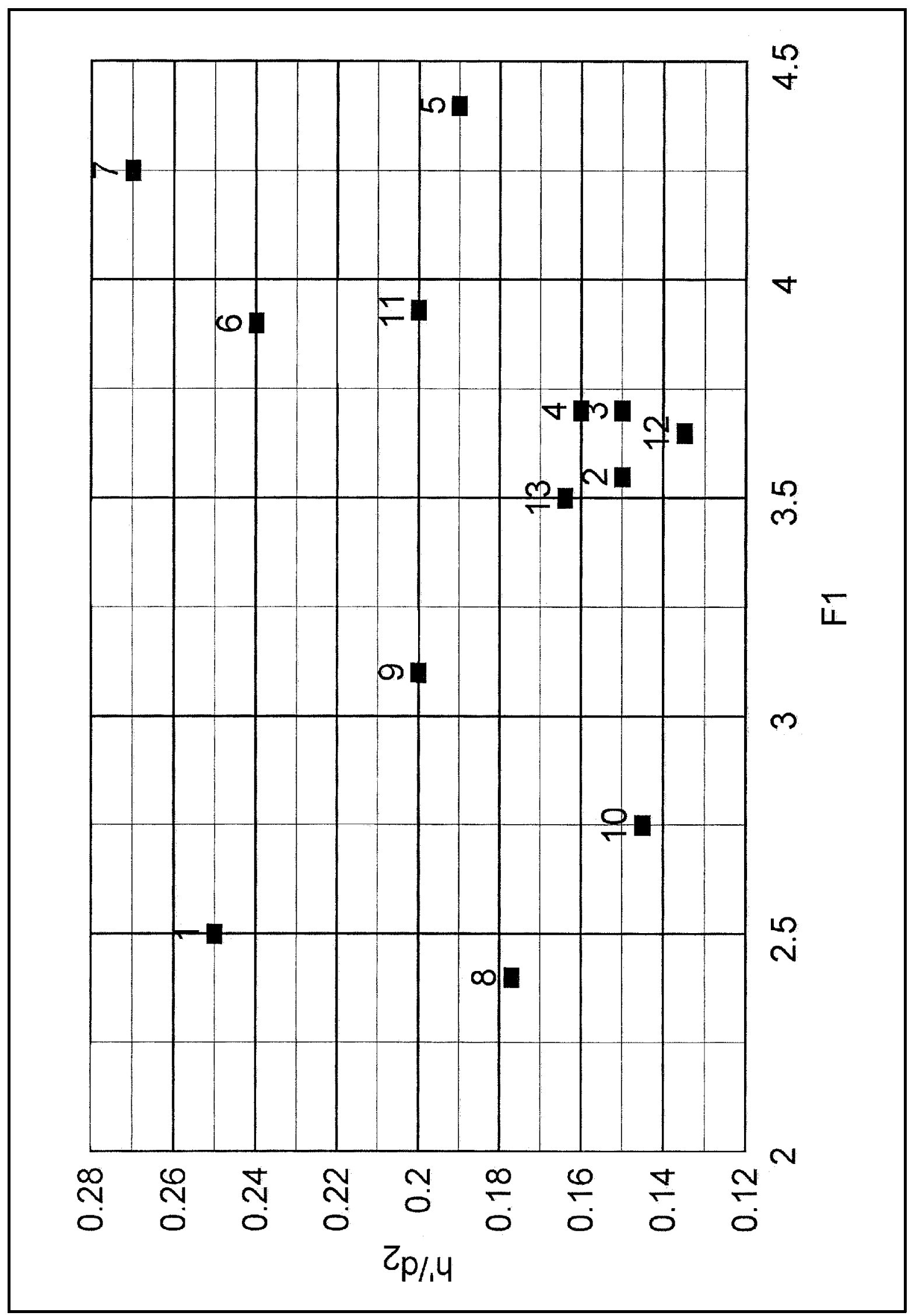

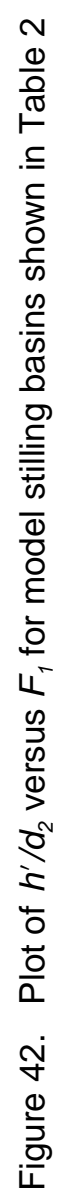




\section{Cavitation and Abrasion Damage}

One should refer to EM 1110-2-1602 and EM 1110-2-1605 (USACE 1987) for information on cavitation and abrasion damage. 


\section{Summary and Conclusions}

The stilling basin design for a low-head navigation dam should consider the features discussed in the previous section and determine if they are suitable for the design in question. Low-head navigation dam stilling basins, as the name suggests, are not sources of high energy and typically have entering Froude numbers between 2.5 and 4.5. Peterka (1963) described hydraulic jumps in this range as having a pulsating action with the entering jet randomly oscillating from bottom to surface. Turbulence occurs near the bottom at one instant and entirely on the surface the next. Also, the jump is very sensitive to tailwater depth at these low values of the Froude number. The nature of this action makes designing an effective energy dissipater for the entire range of flow conditions expected at a project difficult. Model studies should always be considered when finalizing the design for the stilling basin.

The basin apron elevation is an essential element in developing a good energy dissipater. The minimum tailwater is the constraint that often determines this elevation for a stilling basin designed for single-gate operations. Model tests have shown that the apron could be set at $0.8 d_{2}$ for a stilling basin designed using the existing information in EM 1110-2-1605 (USACE 1987). The flow conditions with the apron this high are not particularly desirable since the jet could be on the verge of spraying off the baffle blocks, and this causes considerable turbulence in the downstream channel. The suggestion is that if flow conditions with a single gate fully open and minimum tailwater are expected to occur regularly, that an apron elevation of $0.85 d_{2}$ or greater be used in preliminary design.

The location and height of the first row of baffles are another essential feature of the low-head navigation dam stilling basin. These baffles serve as the impact elements necessary to break up the entering jet and allow adequate energy dissipation. A basin designed for a single gate full open will have lower entering Froude numbers than a basin designed for single gate half open if the upper pool is the same and energy losses between the upper pool and the apron are ignored. The blocks need to be closer to the toe of the trajectory to trigger impact action since the hydraulic jump action in this range of Froude number is not an extremely efficient energy dissipater.

The length of the basin should be longer than a conventional hydraulic jumptype stilling basin because of the stilling action produced in this type of structure. 
The additional length is required to allow energy dissipation to occur over a paved structure rather than in the exit channel. The distance from the toe of the trajectory to the beginning of the upslope (end sill) recommended from the previous model studies is considered to be minimum and is usually designed in conjunction with the $1 \mathrm{~V}$ on $5 \mathrm{H}$ upslope to meet the exit channel constraints. These two elements work together to spread and release flow from the stilling basin that will not cause the downstream scour protection to fail.

The design conditions for low-head navigation dam stilling basins have changed to meet the demands of emergency and unusual operations that past experiences have shown will occur. The modern stilling basin must provide satisfactory performance for adverse flow conditions without the loss of structural integrity. Studies to obtain additional design guidance would be beneficial in the preliminary development of a new stilling basin. Design features that need further investigation are listed below

a. Basin elevation for low Froude numbers (2.5 to 4.0) with tailwaters between 0.7 and $1.0 d_{2}$.

b. Basin length requirements for $T W / d_{2}$ ratios between 0.7 and $1.0 d_{2}$.

c. Baffle height and location for tailwaters between 0.7 and $1.0 d_{2}$.

d. End sill height and length for tailwaters between 0.7 and $1.0 d_{2}$.

e. Gate bay width probably influences the spreading action in the stilling basin designed for single-gate operations; this should be investigated for an appropriate range of widths.

Items $a-e$ should be optimized for stilling basins designed for either single gates operating full open or for single gates operating half open. A model reproducing the three-dimensional flow patterns from single-gate operations with the adjacent gates closed is recommended to finalize the design. 


\section{References}

Basco, D. R. (1970). "An experimental study of drag force and other performance criteria of baffle blocks in hydraulic jumps," Miscellaneous Paper H-70-4, U.S. Army Engineer Waterways Experiment Station, Vicksburg, MS.

Cummins, R. S., Jr., and Grace, J. L., Jr. (1965). "Spillway for typical low-head navigation dam, Arkansas River, Arkansas, Appendix A: Gate sills and stilling basins for Locks and Dams Nos. 5 and 7," Technical Report No. 2-655, Appendix A, U.S. Army Engineer Waterways Experiment Station, Vicksburg, MS.

Grace, J. L., Jr. (1964). "Spillway for typical low-head navigation dam, Arkansas River, Arkansas," Technical Report No. 2-655, U.S. Army Engineer Waterways Station, Vicksburg, MS.

Hite, J. E., Jr. (1982). "Model tests of scour protection for Emsworth Locks and Dams," Summary Report, U.S. Army Engineer Waterways Experiment Station, Vicksburg, MS.

(1984). "Model tests of scour protection for Montgomery Locks and Dam, Ohio River, Pennsylvania," Summary Report, U.S. Army Engineer Waterways Experiment Station, Vicksburg, MS.

. (1987). "Scour protection for Pike Island Dam, Ohio River," Miscellaneous Paper HL-87-6, U.S. Army Engineer Waterways Experiment Station, Vicksburg, MS.

(1988a). "Scour protection downstream from gated low-head navigation dams," REMR Technical Note HY-N-1.6, U.S. Army Engineer Waterways Experiment Station, Vicksburg, MS.

(1988b). "Scour protection downstream of uncontrolled fixed-crest dams," REMR Technical Note HY-N-1.5, U.S. Army Engineer Waterways Experiment Station, Vicksburg, MS. 
Hite, J. E., Jr. (1989). "Scour protection for Morgantown Dam, Monongahela River, West Virginia," Miscellaneous Paper HL-89-4, U.S. Army Engineer Waterways Experiment Station, Vicksburg, MS.

(1993). "Scour protection for Wilbur D. Mills Dam, Arkansas

River, Arkansas," Technical Report HL-93-7, U.S. Army Engineer Waterways

Experiment Station, Vicksburg, MS.

Leech, J. (1990). "Red River Waterway, Lock and Dam No. 4, Report 4, stilling basin and riprap requirements, Red River, LA," Technical Report HL-90-2, U.S. Army Engineer Waterways Experiment Station, Vicksburg, MS.

Maynord, S. T. (1991). "Red River Waterway Lock and Dam No. 3," Technical Report HL-91-10, U.S. Army Engineer Waterways Experiment Station, Vicksburg, MS.

Maynord, S. T., and Markussen, J. V. (1989). "Red River Waterway, John H. Overton Lock and Dam, stilling basin, riprap, and hydropower requirements, Report 4," Technical Report HL-89-16, U.S. Army Engineer Waterways Experiment Station, Vicksburg, MS.

Murphy, T. E. (1980). "Stilling basins for low-head navigation dam spillways," Memorandum for Record, 24 April 1980, U.S. Army Engineer Waterways Experiment Station, Vicksburg, MS.

Oswalt, N. R. (1974). "Spillway for Aliceville Lock and Dam, Tombigbee River, Alabama," Technical Report H-74-10, U.S. Army Engineer Waterways Experiment Station, Vicksburg, MS. (1977). "Red River Waterway, Louisiana, Texas, Arkansas, and Oklahoma, Mississippi River to Shreveport, Louisiana, Reach, Lock and Dam No. 1," Technical Report H-77-13, U.S. Army Engineer Waterways Experiment Station, Vicksburg, MS.

Oswalt, N. R., and Pickering, G. A. (1973). "Spillway for Lock and Dam 26, Mississippi, River, Missouri and Illinois," Technical Report H-73-13, U.S. Army Engineer Waterways Experiment Station, Vicksburg, MS.

. (1974). "Spillway for Columbus Lock and Dam, Tombigbee River, Alabama," Technical Report H-74-13, U.S. Army Engineer Waterways Experiment Station, Vicksburg, MS.

Peterka, A. J. (1963). "Hydraulic design of stilling basins and energy dissipaters," a Water Resources Technical Publication, Engineering Monograph No. 25, United States Department of Interior, Washington, DC. 
Pickering, G. A. (1965). "Spillway for Belleville Locks and Dam, Ohio River, Ohio and West Virginia," Technical Report No. 2-687, U.S. Army Engineer Waterways Experiment Station, Vicksburg, MS.

Pickering, G. A. (1966). "Spillway for Hannibal Locks and Dam, Ohio River, Ohio and West Virginia," Technical Report No. 2-731, U.S. Army Engineer Waterways Experiment Station, Vicksburg, MS.

Pickering, G. A., and Grace, J. L., Jr. (1965). "'Spillway for Cannelton Locks and Dam, Ohio River, Kentucky and Indiana," Technical Report No. 2-710, U.S. Army Engineer Waterways Station, Vicksburg, MS.

Rothwell, E. D., Oswalt, N. R., and Maynord, S. T. (1981). "Grays Landing Spillway and Stilling Basin, Monongahela River, Pennsylvania," Technical Report HL-81-13, U.S. Army Engineer Waterways Experiment Station, Vicksburg, MS.

U.S. Army Corps of Engineers. (1965). "Hydraulic design of spillways," EM 1110-2-1603, U.S. Government Printing Office, Washington, DC.

1602, U.S. Government Printing Office, Washington, DC.

. (1987). "Hydraulic design of navigation dams," EM 1110-2-1605, U.S. Government Printing Office, Washington, DC.

U.S. Army Engineer Waterways Experiment Station. (1958). "Stilling basin for Warrior River, Alabama," Technical Report No. 2-485, Vicksburg, MS.

(1961a.) "Spillway for Markland Locks and Dam, Ohio River, Kentucky and Indiana," Technical Report No. 2-566, Vicksburg, MS.

. (1961b). "Spillway, Greenup Locks and Dam Ohio River, Kentucky and Indiana,” Technical Report No. 2-572, Vicksburg, MS.

(1961c). "Spillway for New Cumberland Locks and Dam (Final Design), Ohio River, West Virginia," Technical Report No. 2-585, Vicksburg, MS.

(1961d). "Spillway stilling basin for Pike Island Locks and Dam, Ohio River, Ohio and West Virginia," Technical Report No. 2-586, Vicksburg, MS.

MS. (1988). "Hydraulic design criteria," 18th Issue HDC, Vicksburg, 


\section{REPORT DOCUMENTATION PAGE}

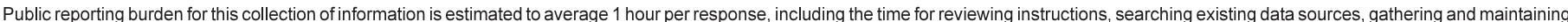

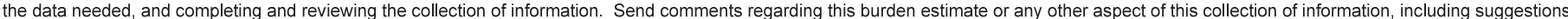

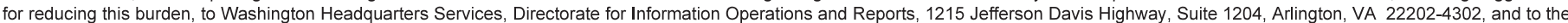
Office of Management and Budget, Paperwork Reduction Project (0704-0188), Washington, DC 20503.

\begin{tabular}{|l|l|l|}
\hline 1. AGENCY USE ONLY (Leave blank) & $\begin{array}{c}\text { 2. REPORT DATE } \\
\text { March } 1999\end{array}$ & $\begin{array}{c}\text { 3. REPORT TYPE AND DATES COVERED } \\
\text { Final report }\end{array}$ \\
\hline
\end{tabular}

\section{TITLE AND SUBTITLE}

5. FUNDING NUMBERS

Low-Head Navigation Dam Stilling Basin Design

\section{AUTHOR(S)}

John E. Hite, Jr.

\section{PERFORMING ORGANIZATION NAME(S) AND ADDRESS(ES)}

U.S. Army Engineer Waterways Experiment Station

3909 Halls Ferry Road, Vicksburg, MS 39180-6199

\section{PERFORMING ORGANIZATION} REPORT NUMBER

Technical Report CHL-99-4

9. SPONSORING/MONITORING AGENCY NAME(S) AND ADDRESS(ES)

U.S. Army Corps of Engineers

10. SPONSORING/MONITORING

Washington, DC 20314-1000 AGENCY REPORT NUMBER

\section{SUPPLEMENTARY NOTES}

Available from National Technical Information Service, 5285 Port Royal Road, Springfield, VA 22161.

12a. DISTRIBUTIONIAVAILABILITY STATEMENT

12b. DISTRIBUTION CODE

Approved for public release; distribution is unlimited.

\section{ABSTRACT (Maximum 200 words)}

Numerous studies have been performed to develop stilling basin designs for site-specific projects. The design that the Corps of Engineers uses for the low-head navigation dam stilling basin is a result of acquiring design guidance from many of these studies. This report provides the historical background and basis for adopting this design guidance as well as additional research performed to refine the low-head navigation dam stilling basin design. The hydraulic conditions for basin design are presented, and design guidance for the various basin elements including basin elevation and length, baffle block location, gate pier extensions, and end sill location are also provided.

\section{SUBJECT TERMS}

Baffle blocks

End sill
Navigation dam

Stilling basin design
15. NUMBER OF PAGES

76

16. PRICE CODE

\begin{tabular}{|l|l|l|}
\hline $\begin{array}{l}\text { 17. SECURITY CLASSIFICATION } \\
\text { OF REPORT }\end{array}$ & $\begin{array}{l}\text { 18. SECURITY CLASSIFICATION } \\
\text { OF THIS PAGE } \\
\text { UNCLASSIFIED }\end{array}$ & $\begin{array}{l}\text { 19. SECURITY CLASSIFICATION } \\
\text { OF ABSTRACT }\end{array}$ \\
\hline
\end{tabular}

NSN 7540-01-280-5500
Standard Form 298 (Rev. 2-89) Prescribed by ANSI Std. Z39-18 298-102 